\title{
El fetiche jurídico del capital: expansión imperialista de su hegemonía sistémica a través de los estudios de derecho
}

\section{O fetiche jurídico do capital: expansão imperialista de sua hegemonía sistémica através dos estudos do direito}

\author{
Antonio Salamanca Serrano(1)
}

\begin{abstract}
Recebido: 06/2016
Aprovado: 08/2016
\end{abstract}

\begin{abstract}
Resumen: Este trabajo nace del enfrentamiento diario con el fetiche del derecho como problema existencial y académico. Se ha convertido en objeto de investigación encontrar respuesta a la siguiente pregunta: ¿qué son los estudios del derecho en relación con el fetiche jurídico del capital? Esta pregunta se desagrega en otros muchos interrogantes y - como queda implícito en la pregunta - el problema tiene alcance regional. El formalismo normativista positivista es el horizonte jurídico hegemónico en América Latina, y también compartido al menos por España y Portugal. Pero ¿será igual fuera de América Latina y de algunos países europeos mediterráneos? Las preguntas tienen pretensión de encontrar respuestas, si es que las hay, más allá de una u otra región o continente. Delimitado y formulado el problema, la búsqueda de explicación a los hechos problemáticos, caóticos y confusos, se va a intentar en un nuevo horizonte paradigmático: el "iusmaterialismo", como método de investigación jurídica, así como teoría ontológica de la realidad jurídica. El "iusmaterialismo" entiende la realidad ontológica del derecho, objeto de la investigación, como un conjunto de relaciones sociales caracterizadas por el poder; en función de la vida de los pueblos y la naturaleza, y su reproducción. Define al "derecho como una praxis (acción) con poder real de satisfacción del sistema integrado de necesidades y capacidades de los pueblos y la naturaleza, positivados como bienes jurídicos autónomamente por la comunidad, con el apoyo de la fuerza tutelar coactiva de la misma".
\end{abstract}

Palabras clave: El fetiche del derecho como problema existencial y académico. "Iusmaterialismo" como método de investigación jurídica. Derecho como praxis.

\begin{abstract}
Resumo: Este ensaio nasceu do enfrentamento diário com o fetiche da lei enquanto problema existencial e acadêmico. Tornou-se objeto de nossas pesquisa com o fito de encontrar resposta para a seguinte pergunta: Que e quais são os estudos jurídicos relacionados com o fetiche jurídico exercido pelo capital? Esta questão é subdividida em muitas outras perguntas e - como está implícito na pregunta central - trata-se de problema com âmbito regional visto que o formalismo positivista-normativista é o horizonte jurídico hegemônico na América Latina e também compartilhado, pelo menos, por Espanha e Portugal. Mas é de indagar se isso expressa da mesma forma fora da América Latina e alguns países europeus do Mediterrâneo. Assim, essas questões têm a pretensão de encontrar respostas - se é que elas existem - para além de uma região ou continente particular. Delimitado e formulado o problema de pesquisa, a busca de explicação para esses fatos aporéticos e caóticos será construída a partir de um novo horizonte paradigmático, o "jusmaterialismo", o qual é aquí compreendido enquanto um método de investigação jurídica e como teoria ontológica da realidade jurídica. O "iusmaterialismo" entende a realidade ontológica do direito objeto de investigação como um conjunto de relações sociais caracterizadas pelo poder e, baseado na vida dos povos, da natureza e de suas formas de reprodução, "define o direito como uma práxis (ação) com efetivo poder de satisfação de um sistema integrado de necesidades e potencialidades, dos povos e da natureza, positivados enquanto bens jurídicos autónomos pela comunidade e com o apoio da força tutelar coativa dessa mesma comunidade".

Palavras-chave: O fetiche da lei como problema existencial e acadêmico. "Iusmaterialismo" como um método de pesquisa jurídica. O direito como praxis.
\end{abstract}

\footnotetext{
${ }^{1}$ Profesor titular del Centro de Derechos y Justicia, Instituto Altos Estudios Nacionales, Quito, Ecuador.
} 


\section{Introducción}

El fetiche es un objeto al que enajenadamente se le atribuye la fuerza de un poder que no tiene y se le consagra obediencia. Ahora bien, si es cierto que el fetiche no tiene el poder que se le atribuye, sin embargo, la "magia, la ilusión" del fetiche consiste en que las energías del "poder" popular de esa atribución errada son utilizadas y transmutadas por una persona o grupos sociales para la violenta dominación de los adoradores.

En eso ha convertido el capital al derecho, un tótem jánico con dos caras. Por un lado, es un guiñapo, impotente. Los derechos a la autodeterminación, al conocimiento, al medio ambiente sano, a la soberanía alimentaria, a la salud, a la vivienda, etc., no son sino puro texto. Se les pronuncia e invoca y no producen nada; una lamentable elegía para los pueblos. Sin embargo, el fetiche tiene un lado oscuro, el poder de las energías de los pueblos es transmutado en violenta alienación, explotación y opresión de quienes le adoran, y persecución a muerte de quienes profética e irreverentemente descubren su engaño, le desobedecen y desafían. Este rostro del fetiche del capital es Moloch, Saturno devorando a sus hijos y sediento de sangre y sacrificios. Los pueblos acaban sometidos, en servidumbre "voluntaria", a los ídolos fabricados por sus propias manos (Marx, [1842] 2007: 77).

Este trabajo nace del enfrentamiento diario con el fetiche, como problema existencial, y académico. Se ha convertido en objeto de investigación encontrar respuesta a la siguiente pregunta: ¿qué son los estudios del derecho en relación con el fetiche jurídico del capital? Esta pregunta se desagrega en otros muchos interrogantes, como por ejemplo: ¿en qué consiste en esencia ese paradigma jurídico? ¿Cuál es su historia? ¿Cuándo comenzó a hacerse hegemónico? ¿Qué ha necesitado para su hegemonía? ¿Qué ámbito o extensión tiene? ¿Cómo funciona el paradigma? ¿Al servicio de qué o para quién funciona? ¿Cuáles han sido y son sus principales actores?

Como queda implícito en la pregunta, el problema tiene alcance regional, no es solo un problema de nuestro país ecuatoriano. En la investigación coordinada por Ch. Courtis, y publicada en 2006 como libro con el título Observar la Ley (Courtis, 2006), se constata que el formalismo normativista positivista es el horizonte jurídico hegemónico en América Latina, y también compartido al menos por España y Portugal.

Pero ¿será igual fuera de América Latina y de algunos países europeos mediterráneos? ¿Existe también ese problema en Estados Unidos, por ejemplo? 
Los estudios y la enseñanza del derecho en Estados Unidos son con frecuencia presentados como ejemplo en muchas facultades de derecho latinoamericanas. Estudios pragmáticos, centrados en el estudio del caso concreto, superador se dice- del deductivismo glosador y exegético que domina en el ámbito jurídico latino. ¿Es esto cierto? ¿Realmente en EE.UU. existe otro paradigma de derecho o es otra tradición dentro de las limitaciones del mismo paradigma? ¿Y fuera del continente americano, cómo son los estudios de derecho en África, Asia y Europa? ¿Padecen los mismos males? ¿Cuál ha sido la historia en los estudios de derecho en esos continentes? Las preguntas tienen pretensión de encontrar respuestas, si es que las hay, más allá de una u otra región o continente. ¿Responden los estudios de derecho actuales en el planeta a un sistema mundo jurídico o son tradiciones relativamente autónomas? ¿De existir ese sistema mundo jurídico, cuándo empieza y por qué? ¿Cuáles serían los factores que lo habrían permitido en su caso? ¿Qué había en las tradiciones jurídicas continentales antes de la dominancia del sistema jurídico hegemónico, de existir algo?

Delimitado y formulado el problema, la búsqueda de explicación a los hechos problemáticos, caóticos y confusos, se va a intentar en un nuevo horizonte paradigmático: el iusmaterialismo, como método de investigación jurídica, así como teoría ontológica de la realidad jurídica. Comenzando por lo último, el iusmaterialismo entiende la realidad ontológica del derecho, objeto de la investigación, como un conjunto de relaciones sociales caracterizadas por el poder; en función de la vida de los pueblos y la naturaleza, y su reproducción. Define al derecho como una praxis (acción) con poder real de satisfacción del sistema integrado de necesidades y capacidades de los pueblos y la naturaleza, positivados como bienes jurídicos autónomamente por la comunidad, con el apoyo de la fuerza tutelar coactiva de la misma.

El iusmaterialismo se inserta en la tradición del materialismo marxista en términos generales y su insurgencia frente al fetichismo jurídico, pero con algunas profundizaciones "heréticas" respecto a cierto dogmatismo en los modos de entender el materialismo histórico marxiano (Marx, [1842] 2007). Esta evolución del materialismo propuesta, que puede ser vista como heterodoxa, pero - que entendemos como una- evolución coherente con los presupuestos del materialismo marxiano, se ha desarrollado en Filosofía de la Revolución. Filosofía para el Socialismo del Siglo XXI (Salamanca, 2008) (aquí le hemos llamado hismatre: materialismo histórico de realidad) y en Teoría Socialista del derecho (Salamanca, 2011).

Entre los principales postulados iusmaterialistas para el marco metodológico hay que destacar: $1^{\circ}$ ) se asume el derecho como una relación social práctica tan última instancia como las relaciones económicas o cualquier 
otro tipo de relaciones sociales. Es decir, el derecho no es reflejo de la relaciones económicas de producción, sino una relación social de poder, de última instancia, que en ocasiones crea las relaciones de poder que permite un sistema económico u otro (así como un tipo de relaciones económicas dan lugar a un tipo de relaciones de poder). Incluso se puede hacer la lectura del capitalismo como un modo moderno de las relaciones criminales de esclavitud de la antigüedad. La expropiación originaria de los medios de producción (K. Marx) no es sino expresión del estado de guerra permanente de un sistema, que llamaremos contraderecho, contra el verdadero derecho de los pueblos y la naturaleza. $2^{\circ}$ ) Lo que caracteriza las relaciones jurídicas como relaciones sociales es el poder; son relaciones de poder; $3^{\circ}$ ) El contenido último del derecho como sistema jurídico, su legitimidad última no radica en la voluntad del soberano o en la voluntad mayoritaria contractual sino en la materialidad del sistema de derechos humanos de los pueblos y de la naturaleza, que positivan el sistema de necesidades y capacidades de aquellos; $4^{\circ}$ ) El derecho es una acotación de la praxis moral biocéntrica; $5^{\circ}$ ) El derecho es consustancialmente praxis política partisana que tiene a la vida y su reproducción como proyecto político, como contenido de la justicia; $6^{\circ}$ ) El derecho es relación social del poder como fuerza pero no como violencia. Fuerza y violencia, como dos modos de ejercicio del poder, son categorías diferentes. La primera da lugar a lo que entendemos por derecho y la segunda a algo monstruoso totalmente diferente, el rostro del fetiche: el contraderecho; $7^{\circ}$ ) El derecho en un dinamismo social revolucionario en esencia; subversión frente a cualquier tipo de opresión y materialización del proyecto político-jurídico de la satisfacción de las necesidades/capacidades de vida de los pueblos y la naturaleza (de los derechos de los pueblos y la naturaleza como sus bienes jurídicos).

El iusmaterialismo, metodológicamente, es un método de investigación con pretensión científica en una pluralidad de modos interdisciplinares e interculturales. Su unidad estructural se articula en tres fases: $1^{\circ}$ enfrentamiento o aprehensión de los hechos caóticos y confusos; $2^{\circ}$ elevación de lo concreto a lo abstracto en cierto distanciamiento propio del análisis sistémico de los hechos. El análisis de las partes y su resignificación como piezas del sistema, así como del todo el sistema. Esto es posible desde los distintos paradigmas, con sus conceptos y categorías; $3^{\circ}$ Formulación de postulados explicativos y probación con los hechos, como verificación o falsación. La unidad estructural del método se expresa, como hemos indicado, en una rica pluralidad de modos en el acercamiento, análisis sistémico y probación de la realidad: modo histórico jurídico, socio jurídico, ántropo jurídico, psico jurídico, axiológico jurídico, ideológico jurídico, económico jurídico, lingüístico jurídico, normativo jurídico, jurisprudencial, etc. Lo que hace a esta pluralidad de modos investigación 
propiamente jurídica es la mirada que tiene como pretensión el conocimiento del derecho en general o materializar derechos en particular. No es un método ecléctico. De las diferentes otras disciplinas se toman las técnicas, pero la mirada y el objetivo es propio del derecho (Salamanca, 2015).

En este caso, el modo escogido como más apropiado para la investigación es el histórico-ideológico jurídico. En cercanía con la perspectiva del historicismo jurídico crítico (Lecuona, 2006) de R. W. Gordon (Gordon, 1981, 1984, 1987, 1988, 2002), como izquierda en el movimiento Critical Legal Studies, asumimos la historia como ciencia del decurso temporal de las relaciones sociales. La historia jurídica, en este caso, como la ciencia del decurso temporal de las relaciones sociales de poder. Acometemos la investigación de los estudios de derecho en su dinamismo histórico, sistémico, para poder explicar mejor qué y por qué son lo que son hoy. Hemos enriquecido interdisciplinarmente el modo histórico con otro: el modo ideológico jurídico. Los estudios de derecho son estudios fundamentalmente político ideológicos. Responden a una u otra ideología. Las facultades de derecho, los profesores, los alumnos, el diseño de los currículos, sus contenidos, las publicaciones, etc., son actos eminentemente político ideológicos donde se disputa la producción, circulación y apropiación de la plusvalía ideológico jurídica (Silva, 1970, 1976, 1983). El dinamismo histórico de los estudios de derecho lo hemos querido ver con su carga ideológica a la hora de acercarnos y analizar sistémicamente a los hechos históricos (Kennedy, 1970, 1982, 1984, 2006). La pretensión de este modo histórico-ideológico es abiertamente partisana: emancipadora de los derechos de los pueblos frente a toda forma de servidumbre, también frente a la servidumbre "voluntaria" moderna (De La Boétie, [1548-1549?]1935). El enfoque que hemos tomado es el cualitativo: valoración cualitativa de datos, acontecimientos y movimientos histórico-ideológicos.

La técnica de obtención de datos es fundamentalmente la documental bibliográfica. En cuanto técnicas de análisis sistémico, hemos considerado la correlación histórico sistémica de algunos elementos o variables: a) los currículos en la enseñanza del derecho a nivel regional; b) el papel histórico de las facultades y escuelas de derecho; c) la metodología y pedagogía en la enseñanza del derecho; d) la codificación; e) el legicentrismo; f) el colonialismo jurídico del capital; g) el fetichismo jurídico; h) la costumbre como praxis jurídica tradicional de los pueblos. Y como técnica de probación o verificación, recurrimos a la propia de la investigación histórica: el potencial explicativo de los dinamismos históricos encontrados.

Este trabajo no da cuenta de las resistencias históricas de los movimientos periféricos, marginales y contrahegemónicos en los estudios del derecho. Un trabajo, por otra parte, necesario para completar la realidad de la 
actual correlación de fuerzas. Un análisis necesario para avivar la esperanza de quienes, por más imponente que se exhiba el fetiche del capitalismo jurídico hoy día, como David tenemos la pretensión de vencerlo.

La investigación tiene tres niveles, como lecturas el trabajo, y que lo estructuran. Una primera es la presentación informativa de los estudios del derecho en las diferentes regiones de nuestro mundo. La segunda es la búsqueda histórica de las concatenaciones de los acontecimientos, la vinculación entre posibles causas y efectos, la direccionalidad del movimiento histórico en relación con los estudios del derecho presentados. La remontada histórica se hace del presente hacia atrás. La tercera lectura es el rastreo del factor ideológico en el movimiento de los acontecimientos históricos en búsqueda de su potencial explicativo.

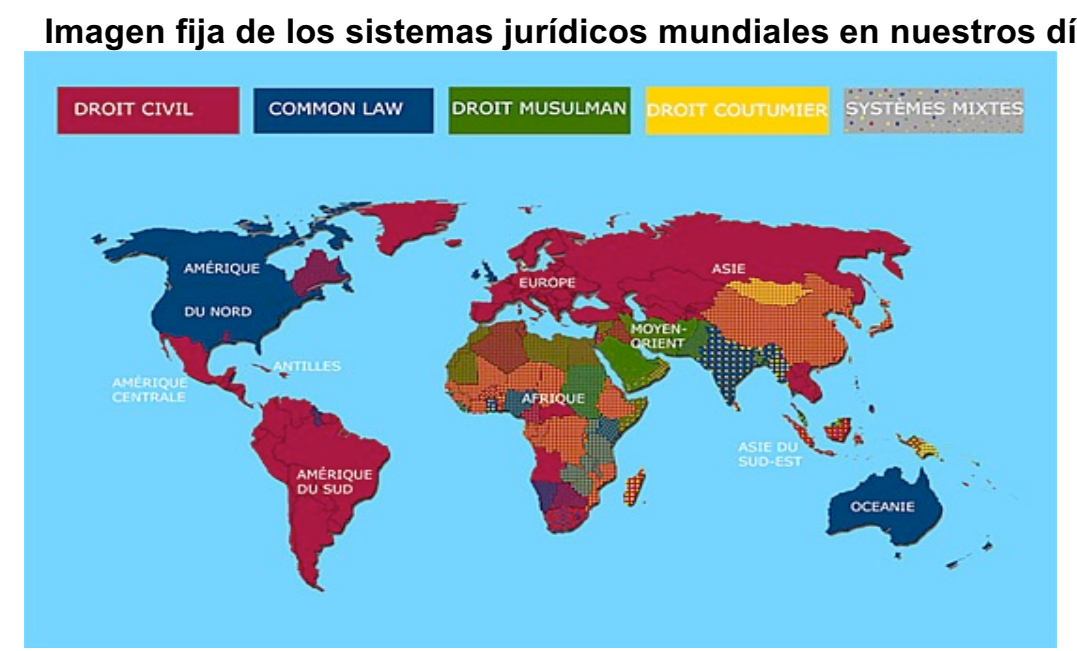

Fuente: Lilia Benaïssa, Universidad de Otawa, Canadá.

\section{Los estudios de derecho en África}

§1. El sistema jurídico africano con sus estudios de derecho, afecta directamente a las relaciones de poder de una población aproximada de 1.166 millones de personas, con datos de 2016. El sistema está integrado por cuatro tradiciones: la romano-germánico, la common law, la islámica y la consuetudinaria (tradicional). Las dos primeras hegemonizan el currículo formativo de los estudios de derecho. Según los países, la estructura de la formación inicial de grado varía de dos años, en unos países, a cuatro, en otros. Luego le sigue la maestría y el doctorado.

Tomando como ejemplo a la Universidad de Ghana, los estudios jurídicos en grado se estructuran en dos años (48 cursos, con 72 créditos para la 
graduación; entre 18 y 21 créditos cada semestre. Todos los cursos son de tres créditos). Existen materias obligatorias y materias optativas.

Primer año: A. Primer Semestre. Cursos obligatorios: sistema legal de Ghana, derecho de contratos I, derecho constitucional I (teoría constitucional), derecho de responsabilidad civil I, propiedad inmueble I (derecho consuetudinario de la tierra), derecho penal I (principios generales); Cursos electivos: derecho internacional público I, derecho comparado I (tradiciones legales).

B. Segundo Semestre. Cursos obligatorios: método legal, derecho de contratos II, derecho constitucional II (constitución de Ghana), responsabilidad civil II (negligencia y difamación), propiedad inmueble II (principios y teoría de la propiedad inmueble), derecho penal II (delitos en particular); Cursos electivos: derecho internacional público II, derecho comparado II (derecho constitucional comparado).

Segundo Año. A. Primer Semestre. Cursos obligatorios: jurisprudencia I, equity; Cursos optativos: ensayo, derecho comercial internacional y de inversión I, derecho de los recursos naturales I, derecho medioambiental I, derecho de propiedad intelectual I, conflicto de leyes I, derecho humanitario I, derecho internacional de los derechos humanos I, género y derecho I, derecho de familia I, derecho tributario I, derecho mercantil I, derecho comercial I, criminología I, derecho administrativo.

B. Segundo Semestre. Cursos obligatorios: jurisprudencia II, derecho de sucesiones; Cursos optativos: derecho comercial Internacional y de inversión II, derecho de los recursos naturales II, derecho medioambiental II, derecho de propiedad intelectual II, conflicto de leyes II, derecho humanitario II, derecho internacional de los derechos humanos II, género y derecho II, derecho de familia II, derecho tributario II, derecho mercantil II, derecho comercial II, criminología II (Manteaw, 2008: 910-72).

En el ámbito del posgrado, maestría y doctorado, tomando como ejemplo la Universidad de Ghana y la Universidad de la Ciudad del Cabo, en Sudáfrica, los estudios e investigaciones jurídicas generalmente se realizan en los siguientes campos: derecho internacional, armonización del derecho de negocios, derecho de propiedad intelectual, derecho comparado, jurisprudencia, derechos humanos, democratización y gobernanza en África, derecho humanitario, derecho consuetudinario familiar, mediación y arbitraje, derecho de seguros, regulación jurídica de la bioseguridad en África, derecho laboral, derecho medioambiental, derecho de los refugiados ${ }^{2}$.

\footnotetext{
${ }^{2}$ Campos o ámbitos de los proyectos de investigación en la Facultad de derecho de la Universidad de Ghana y Universidad de Ciudad del Cabo, Sudáfrica 2015.
} 
Ahora bien, desde los sectores académicos más críticos, con visión prospectiva para las próximas décadas, se reclama abrir el currículo y la investigación jurídica a algunas de las urgencias de la realidad africana. Entre esos nuevos campos de estudio demandados cabe mencionar: a) el fortalecimiento del pluralismo; b) el derecho consuetudinario; c) el derecho a la salud (particularmente caso de $\mathrm{VIH}$ ): d) derecho al agua; e) el derecho al transporte; f) el derecho administrativo; g) el derecho de transparencia y honestidad social e institucional (Manteaw, 2008: 939).

Pero las críticas apuntan más allá. El currículo actual de los estudios de derecho en muchas facultades poco ha cambiado del que quedó fijado en los años 60 y 70 . Sigue evidenciando la tendencia de los inicios de la independencia: el fuerte componente del llamado derecho privado, particularmente comercial y litigante, con relegación formativa del llamado derecho público. El colonialismo en los estudios jurídicos, de lo que en adelante llamaremos fetiche del capital, fue "libremente" reasumido después de la independencia en el siglo XX. El paradigma jurídico capitalista colonial e imperial, en sus tradiciones romano germánica y common law, no permite dar respuesta a la necesidad de decolonialidad jurídica, interculturalidad e interdisciplinariedad que tiene el continente. Más bien es un traje jurídico obturante del desarrollo de posibilidades propias para el crecimiento jurídico de los pueblos africanos. Con frecuencia, los estudios e investigaciones no responden a las necesidades locales y nacionales, no dialogan con ellas, no recuperan ni se fundamentan en el sistema de valores de las antiguas tradiciones africanas.

Además de una urgente revolución de los currículos jurídicos, la transformación del derecho en África requiere recursos para su democratización. Recursos para el acceso a la formación y recursos para la docencia e investigación jurídica. Hoy el acceso a la formación universitaria es un privilegio de muy pocos. Los juristas africanos que salen graduados, haciendo uso del estatus de poder universitario, en su mayoría, terminan siendo parte de la élite social comprometida en servir a los intereses del mercado mundial, casi siempre contra los intereses de sus pueblos. Para quienes apuestan por la vida académica, el futuro es uno o varios trabajos docentes precarios en salario y recursos académicos (Manteaw, 2008: 932).

§2. Pero ante esta realidad colonial que determina el tipo y la estructuración de los estudios e investigaciones jurídicas cabe preguntarse: ¿por qué es lo que es y no otra cosa? Una primera respuesta se aventura por el camino del proceso político africano reciente en el siglo XX. Los currículos de derecho en África son en su mayor parte expresión del proceso de reorganización de la formación jurídica después de la independencia política (formal). Siguiendo a S. O. Manteaw, lo que buscaban los dirigentes 
independentistas era conseguir la estabilidad política, el nuevo diseño constitucional, el desarrollo económico y la seguridad de la propiedad individual. El derecho era un mero instrumento para conseguir aquellos objetivos políticos. Del paradigma voluntarista y positivista que instrumentaliza el derecho no se consiguió la emancipación, si es que en algún momento se buscó con determinación. El fetiche jurídico del capital seguirá colonizando jurídicamente todo el continente africano. Para reforzarlo se crearon rápido las universidades y facultades de derecho y se agilizó el proceso de codificación. Por ejemplo, en 1959 la Universidad de Ghana admite a sus primeros 28 estudiantes de derecho (de ellos se graduaron 18 en 1963). En 1972 ya había 43 universidades en el continente con facultades de derecho (12 sudafricanas, 9 en los países musulmanes del norte de África, y 22 en los países del centro continental). El número de universidades ha ido creciendo hasta alcanzar la cifra de unas 600 hoy en día, aproximadamente un tercio de ellas con facultades de derecho. Sin embargo, su distribución también evidencia las desigualdades regionales. Nigeria y Sudáfrica concentran un buen número, mientras hay algunos países que no tienen (Manteaw, 2008: 954). Lejos quedará la sensibilidad y el compromiso político, determinado en las vísperas de la independencia, en descolonizar África, también del modo jurídico con que la burguesía imperialista del capital, con sus élites locales, veía la realidad africana (Manteaw, 2008: 908; 917).

La independencia política no significó independencia de las relaciones sociales de poder (jurídicas) de las antiguas metrópolis ni del nuevo imperialismo del capital y su sistema jurídico. La independencia africana no lo fue del fetiche jurídico del capital en sus tradiciones romano germánicas y del common law las descolonizaciones jurídicas demoran siglos en materializarse una vez comprometidas; son de las que más tiempo requieren para hacerse hegemónicas, decía Dostoievski- Por ejemplo, dependiendo de la zona de influencia colonial, en África se asumieron la codificación civil y penal francesa o inglesa respectivamente. En casi todos los países se desató la fiebre codificadora; rebajada en algunos casos por la lucha de grupos minoritarios que deseaban recuperar instituciones y prácticas propias de la tradición jurídica africana. Con todo, la hegemonía del colonialismo jurídico tuvo y tiene que enfrentar la pervivencia de la resistencia jurídica consuetudinaria, que se niega a desaparecer. Esta resistencia popular se explica por la cercanía en la producción de los derechos, su accesibilidad a la realización de la justicia, la mayor democratización y flexibilidad. 
de la sociedad africana y no han podido alterar su comportamiento. Más allá del aspecto estrictamente formal, los campesinos en particular continúan viviendo como habían vivido sus ancestros, ignorando el derecho de las urbes y las instituciones puestas en marcha por los reformistas. Conforme a las voces más autorizadas, entre un 80 a $90 \%$ de la totalidad de la población africana continúa viviendo según el modo antiguo, al margen de todo movimiento de modernización. El matrimonio consuetudinario, la poligamia, la dote, entre otras instituciones, si bien han sido suprimidas o reglamentadas, son ampliamente observadas en la práctica. En Costa de Marfil "la mayoría de los individuos no aceptan las prácticas nuevas y las instituciones consuetudinarias están todavía vigentes". La costumbre de antaño continúa siendo observada de facto, los tribunales estatales abandonados en beneficio de arbitrajes administrados 0 , más frecuentemente, de conciliaciones logradas de acuerdo a la tradición" (David y Jauffret-Spinosi, 2010: 422).

§3. Ahora bien, la (de)formación jurídica africana no comienza con la independencia de mediados del siglo XX. ¿Qué paradigma jurídico formativo, con sus estudios de derecho, era el hegemónico antes de la independencia político institucional formal del siglo XX?, ¿qué características tenía y cómo condicionaba la formación y los estudios de derecho? En búsqueda de respuestas, encontramos que la colonización introdujo en África la "formalización de la educación jurídica" según el modo académico universitario europeo, así como el paradigma litigioso, de representación jurídica, etc. El proceso se aviva con la invasión colonial del siglo XIX y su influencia se alarga durante todo el siglo XX, llegando a esta nueva centuria del siglo XXI. La colonización europea (belga, británica, española, francesa, italiana, portuguesa, etc.) del continente africano desata una era de imposición normativa en búsqueda de su hegemonía ideológico-jurídica: el dominio de un paradigma de derecho al servicio del capital de las metrópolis. Los abogados son una pieza cada vez más necesaria. A modo de ejemplo, en Nigeria se pone en marcha un proceso de formación profesional legal en 1862, regulándose la profesión y formación del abogado en 1876. Con todo, hasta 1945 se permitía actuar como "abogados" a aquellos autodidactas que conocían el oficio por haber aprendido trabajando de cerca con algún abogado. Lo mismo se admitía en Ghana desde 1853, con tal que conocieran el procedimiento y los principios generales del sistema jurídico (Manteaw, 2008: 912-913).

Reparto colonial imperial de África S. XIX 


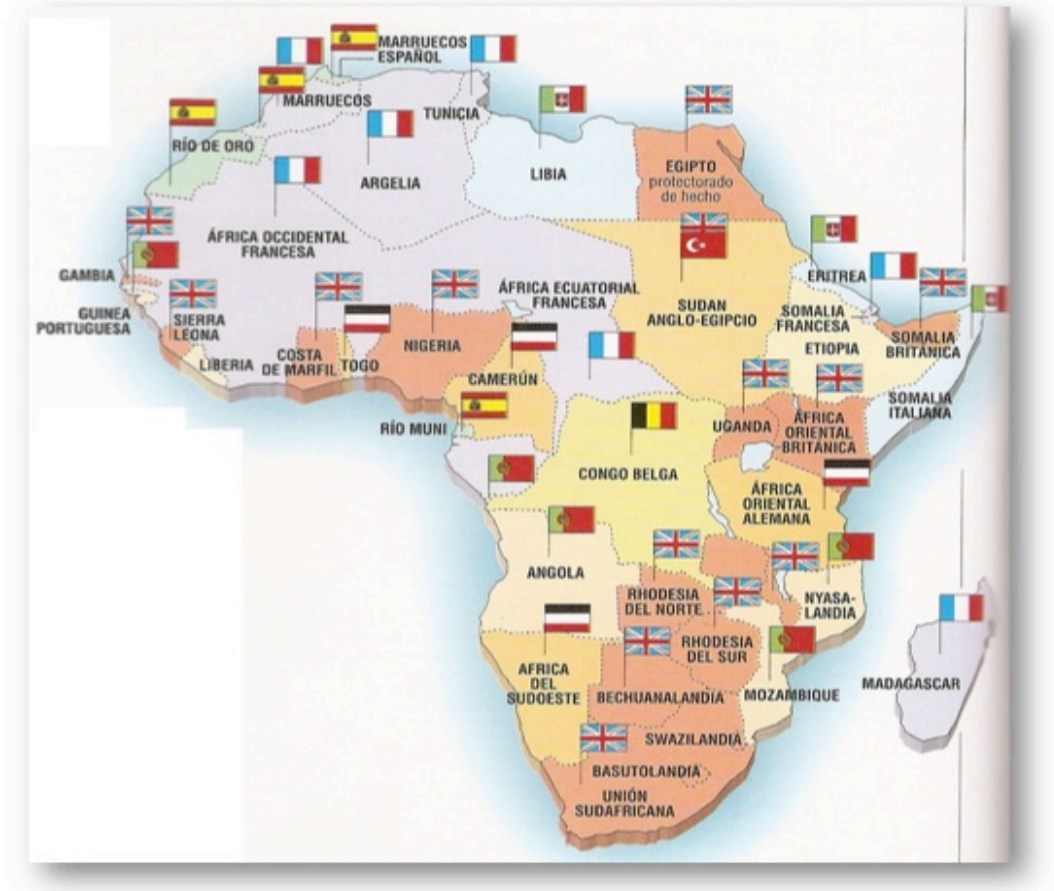

Fuente: http://campus.ort.edu.ar/articulo/278212/imperialismo

Se utilizó el derecho romano germánico o common law para invadir, legitimar y reforzar el dominio, pero se evitaba la formación jurídica empoderativa de los pueblos para evitar que utilizasen el instrumento en su liberación. Se tenía mucho cuidado con quienes querían estudiar leyes. En ellos se veía el peligro de los potenciales dirigentes anticoloniales. Desde luego esta política de control formativo no solo era en el campo jurídico sino también en otras disciplinas. Cuando Zambia se libera del colonialismo británico, en 1964, solo tenía 100 graduados universitarios, todos en el campo de la educación, salvo dos doctores y un ingeniero. Malawi contaba con apenas 23 universitarios en 1959, y hasta 1964 el país no tuvo universidades. Por otro lado, quienes querían estudiar derecho tenían que hacerlo en las metrópolis. Los escasos candidatos que se decidían y podían costearse la formación y estudios jurídicos debían ir a Londres, en el caso del dominio británico, o a otras metrópolis imperiales. En la práctica, solo podían estudiar los ricos. El pueblo africano quedaba excluido del acceso al poder del conocimiento. Los juristas que llegan al continente en su mayor parte eran extranjeros y formados en el extranjero. llustra el dato que en Tanzania, todavía en 1961, solo uno de cada 100 abogados era del país; 10 en Kenia, de 300; y 20 de 150 en Uganda. El currículo en que se habían formado era fundamentalmente etnocéntrico (europeo), capitalista y, en su caso, fetichizado 
en el normativismo. Es decir, por un lado, la formación que habían recibido era la propia británica o europea continental, ajena a la realidad africana y de espaldas al pluralismo jurídico consuetudinario africano. $Y$, por otra parte, los estudios en los que se habían preparado eran esencialmente en el ámbito privado; orientados fuertemente hacia el derecho comercial, mercantil, de negocios, y litigación (Manteaw, 2008: 913-916).

La hegemonía se va imponiendo en un proceso sin tregua contra las resistencias jurídicas locales. Los modelos y horizontes de pensamiento propios del derecho romano germánico y common law se importan con desprecio y desperdicio de la tradición africana: desvalorización, ocultamiento y destrucción de sus propios sistemas jurídicos consuetudinarios. Las autoridades tradicionales que se encargaban de la resolución de los conflictos fueron progresivamente desplazadas por funcionarios al servicio de la metrópoli. El contenido del derecho propio quedó reducido a simples aspectos del ámbito familiar. Algunos intentos de codificar estas costumbres se hicieron bajo el dominio colonial francés. Intentos limitados en su extensión y muy fragmentados. Allí donde se aplicaba el derecho consuetudinario africano, este quedó desnaturalizado; pervirtiendo su búsqueda de armonía comunitaria en la fiebre individualista por ganar la victoria litigiosa al rival (David y Jauffret-Spinosi, 2010: 428).

\footnotetext{
“... se modificó el orden social que regulaban su existencia por otros medios y que no estaban preparados para aceptar la noción europea moderna de derecho. La civilización africana estaba fundada en ciertos valores: el espíritu de comunidad, el respeto por los ancianos, la ausencia de clases antagónicas, entre otros muchos. Se aceptó demasiado fácil que esos valores sean destruidos sin preocuparse de reemplazarlos por valores nuevos; se forzó así de manera inconsciente el relajamiento de los vínculos familiares y de clan, sin que se pudiera introducir, la solidaridad del cuerpo social en su conjunto" (David y Jauffret-Spinosi, 2010: 433-34).
}

El colonialismo inglés de protectorado, como hemos indicado, optó por el desconocimiento del derecho tradicional africano. No había mucho tiempo que perder. El capitalismo necesitaba acelerar la expropiación originaria en África y someter las relaciones de sus pueblos con la tierra, comunitarias y comerciales al nuevo sistema jurídico burgués:

"La elaboración de un derecho nuevo se impuso en ciertos ámbitos, especialmente en el ámbito del derecho mercantil moderno. El derecho consuetudinario, se limitaba a regular ciertos contratos, de número reducido, específicamente concernientes al ámbito rural; el derecho de sociedades mercantiles, de efectos de comercio, el derecho marítimo, y el derecho de contratos en su conjunto, debieron ser importados del Occidente. Conforme a las concepciones tradicionales africanas el trabajo era, más que una forma de ganarse la vida, un modo de vida vinculado con las fuerzas de la naturaleza que involucraba la realización de los ritos; así la noción de contrato de trabajo, que es el mecanismo legal a través del cual se asumía la obligación de trabajar 
para un extranjero para obtener en contraprestación un salario, resultaba inimaginable. El derecho del trabajo tuvo también, que ser importado de Occidente en el momento en que la mano de obra asalariada hace su aparición. Las costumbres por otra parte se habían desarrollado para regir las relaciones entre miembros de comunidades, practicando el modo de vida indígena" (David y Jauffret-Spinosi, 2010: 428).

§4. Ciertamente el siglo XIX supuso en África la invasión y expansión hegemónica del fetiche jurídico imperial del capital, con sus estudios de derecho. Ahora bien, el colonialismo jurídico africano del siglo XIX tiene sus raíces más atrás en la historia. Ya en Etiopía, los Amharas se convierten al cristianismo, y a su derecho, en el siglo IV d.C. El proceso de cristianización "jurídica" de África continuó desde entonces hasta nuestros días. Hoy aproximadamente el 46,53\% del continente profesa el cristianismo (predominante en 31 estados; unos 500 millones) $)^{3}$. Por su parte, el Islam, también con su derecho, llegó pronto a África, en el siglo VII. Hacia el siglo XI esta nueva religión consigue la islamización de parte de norte occidental africano. Proceso que se extenderá hacia la parte oriental africana, Sudán, Somalia, etc., desde el siglo XIV. La población islámica africana es aproximadamente de 40,46\% (predominante en 21 estados). Con la llegada de los cristianos y musulmanes llegaron también textos y tradiciones jurídicas inspirados en el derecho canónico o en el Corán y la Sunna. En Etiopía, por ejemplo, los cristianos acogieron la codificación jurídico religiosa elaborada en Egipto en el siglo XIII (David y Jauffret-Spinosi, 2010: 425). A pesar de ello, la religiosidad tradicional, con su derecho, resiste y representa el $11,8 \%$ (predominante en 6 estados).

Ahora bien, ¿con qué paradigma jurídico se encontraron los cristianos y musulmanes a su llegada a África? ¿Eran pueblos con derecho o sin derecho? ¿Qué relaciones jurídicas tenían? ¿Había formación jurídica? Ciertamente que sí. Sería un error etnocéntrico creer que antes de la implantación colonial de las universidades y facultades de derecho en el siglo XIX no había ni derecho ni formación jurídica en África. Ciertamente no tenían un sistema "formal" de enseñanza pero había enseñanza jurídica y sistemas de derecho (Manteaw, 2008: 910). El paradigma de pluralismo jurídico consuetudinario fue el dominante en África continental y Madagascar por miles de años. Incluso hoy se puede decir que tiene una gran influencia y se sigue disputando los sentidos jurídicos contra el fetiche normativista del capital. Un sistema consuetudinario múltiple y plural por el mismo modo de organización tribal dominante en los pueblos africanos (v.gr. monárquico, democrático, matriarcal, patriarcal, etc.). Así por ejemplo, solo en la antigua África ecuatorial francesa y el antiguo Congo belga se pueden

\footnotetext{
${ }^{3}$ Según datos del sociólogo Massimo Introvigne ofrecidos en 2012 en el marco del Congreso organizado por el Centro de Estudios sobre las Nuevas Religiones (CESNUR) en la universidad de El Jadida, en Marruecos.
} 
diferenciar unas 1.500 etnias; en Sudán, 579; en África oriental inglesa, 200; en Madagascar, 19. Cada comunidad nómada o etnia, recolectora y/o ganadera, o sedentaria y agrícola, ha sido con frecuencia autosuficiente jurídicamente. Un derecho no escrito de trasmisión oral milenario (David y Jauffret-Spinosi, 2010: 422).

La enseñanza del derecho era un proceso comunitario cotidiano e informal que duraba toda la vida. En esta escuela se aprendían, y aprenden, las prácticas jurídicas que tienen que ver con la moralidad, la propiedad de bienes muebles o inmueble, la herencia. Los jefes de las tribus y ancianos (como maestros del derecho) aprendían ellos mismos de la comunidad. De allí obtenían sus conocimientos y sabiduría jurídica. Los miembros de la comunidad aprendían a defenderse jurídicamente ellos mismos, porque no había representación generalmente. La armonía comunitaria era la razón de ser. El litigio como recurso extremo era expresión de un fracaso (Manteaw, 2008: 911). Cuando se producía el conflicto, en algunos pueblos era frecuente, y lo sigue siendo, la intervención del jefe de la tribu, el subjefe, el cabeza de familia o linaje y otras personas con ciertas responsabilidades jurídicas ( $v$.gr. tendaana en Ghana). En otros lugares existen los llamados "lingüistas" que tenían funciones de mediadores entre las partes en disputa y las autoridades. Estos lingüistas son oradores o recitadores de los "proverbios jurisprudenciales" que reactualizan la memoria jurídica consuetudinaria del pueblo o tribu (Manteaw, 2008: 911).

Dada la diversidad del rico pluralismo jurídico consuetudinario de los pueblos africanos que ha pervivido durante miles de años hasta nuestros días, ¿se pueden identificar elementos jurídicos comunes? ¿Cuáles son los principales rasgos que comparten los diversos sistemas de derecho en la tradición africana anterior al colonialismo? La historia jurídica comparada sostiene que sí, que es posible identificar características comunes dentro del pluralismo jurídico originario africano. Entre los principales destacan: a) la ley para los pueblos es conducir la vida personal y colectivamente según lo hicieron los antepasados. El respecto a la costumbre es expresión del respeto a los antepasados cuyos espíritus conviven con la comunidad de los vivos; b) la tierra es disfrutada por los vivos, como lo fue por los antepasados y lo será por las generaciones futuras. No es de la tradición jurídica africana el pretendido derecho a la propiedad privada de la tierra; c) la comunidad es la unidad sobre la que se edifica la vida social. La persona adquiere identidad y sentido de su existencia dentro de aquella; d) el derecho es parte de la praxis moral, sin fácil distinción entre los límites de uno y otra en muchas ocasiones; e) son ajenas a la tradición jurídica consuetudinaria africana, distinciones entre derecho público y privado, derecho civil o penal, mercantil o laboral, etc.; f) en caso de conflicto el proceso, flexible y poco institucionalizado, lo que busca es restaurar la armonía 
de la comunidad, más que declarar a uno vencedor en su pretensión sobre otro. Incluso en algunos casos de conflicto el potencial vencedor cede sus derechos en función de fortalecer la armonía comunitaria (David y Jauffret-Spinosi, 2010: 422-24).

$5 \S$ En este momento, dada la extensión del ámbito de influencia, más de mil millones de personas en una gran diversidad de países repartidos por los distintos continentes, conviene hacer un breve alto sobre ¿qué ha ocurrido con el derecho islámico, y sus estudios, en África?, y ello vale también para las otras regiones del mundo.

Pues bien, en la actualidad, casi la totalidad de las universidades de los países que se declaran musulmanes, o que tienen al islam como religión mayoritaria, asumen como paradigma jurídico hegemónico de hecho el propio del fetiche del capital, en alguna de sus dos tradiciones: el romano germánico o el common law. Es cierto que en las facultades de derecho (laico) el contenido de los planes de estudio acogen el derecho occidental así como parte del derecho musulmán de autoría divina (sharía). Sin embargo, el derecho musulmán (fiqh), entendido como el ámbito de la interpretación humana de los principios y doctrina (sharía) ha quedado progresivamente relegado al derecho que regula las relaciones familiares y algunas expresiones de contenido religioso. En las facultades de sharía también se enseña el derecho occidental, comparativamente y complementariamente, dado que se necesita conocerlo para el ejercicio de la profesión (An-Naim, 2007: 12). Esto ha sido posible, en parte, por la colaboración de abogados y profesores de derecho que después de la descolonización política, se convirtieron en agentes del dinamismo de reforzamiento de la colonización jurídica occidental. Las primeras generaciones de abogados y académicos, formados en las universidades occidentales, regresarán para encargarse de la dirección política de sus países, así como para la dirección de las grandes corporaciones y firmas de abogados (An-Naim, 2007: 23).

El canon del sistema jurídico musulmán está siendo sometido a grandes tensiones en nuestros días además de por su fijación dogmática, por las exigencias del fetiche jurídico del capital (v.gr. las del comercio internacional). Adoración a la que se han inclinado en la práctica muchos de los países musulmanes, como han hecho los cristianos y otras confesiones religiosas. El Dios vivo ha sido vendido por Mammón. De momento el recurso a ciertas estrategias y ficciones está sirviendo en el intento de conciliar la ortodoxia y la ortopraxis: 
polígamo, no observa el mismo trato que con sus otras esposas. El mutuo con interés conforme al derecho musulmán está prohibido; pero esta se elude a través de una doble venta, o incluso confiriéndole al mutuante, a título de garantía, el uso y goce de un bien de productos. Se debe igualmente considerar que la prohibición del mutuo con interés concierne exclusivamente a las personas físicas, ya que son las únicas que pueden cometer un pecado: a los bancos, a las casas de ahorro y a las sociedades se les libera de esta prohibición. El arrendamiento de la tierra está prohibido; esta prohibición se elude a través de la noción de asociación entre el arrendador y el arrendatario. Los contratos aleatorios, en particular el contrato de seguro, están prohibidos; más sin embargo este pecado no se comete por quien percibe la prima; por lo que se contrata el seguro con una compañía de seguros o con una persona física que no profese la religión islámica. La prohibición misma del seguro desaparece en el caso de las mutualidades de seguro; el énfasis se pone sobre la premisa de solidaridad que la operación involucra y que por ello se propicia su celebración; este contrato está muy lejos de estar prohibido" (David y Jauffret-Spinosi, 2010: 345-346).

$6 \S$ En la realidad actual jurídica de los estudios del derecho en la comunidad musulmana tiene una influencia determinante la etapa de colonialismo occidental, particularmente en los siglos XIX y XX. A los países sometidos se les impuso el derecho occidental burgués en una progresiva extensión de su hegemonía. Ese proceso se evidencia con las "capitulaciones" del imperio otomano, en 1924, a los pies del imperialismo capitalista occidental (An-Naim, 2007: 20).

\begin{abstract}
"Aunque este proceso se desarrolló de formas diferentes entre las sociedades islámicas, la experiencia de la última época del Imperio Otomano es la que probablemente ha tenido las consecuencias más trascendentales. Las concesiones hechas por el Imperio Otomano a las potencias europeas durante el siglo XIX establecieron el modelo para la adopción de los códigos y sistemas occidentales de la administración de justicia. Los edictos del Imperio Otomano justificaron los cambios no sólo para fortalecer el estado y preservar el Islam, sino que también pusieron de relieve la necesidad de asegurar la igualdad entre los súbditos otomanos, sentando así las bases para la adopción del modelo europeo de estado y de su sistema legal. Esas reformas introdujeron en el derecho otomano un Código Comercial de 1850, un Código Penal de 1858, un Procedimiento Comercial de 1879, un Código de Procedimiento Civil de 1880, y un Código de Comercio Marítimo, siguiendo el modelo de derecho civil europeo de intentar lograr una promulgación integral de todas las normas relevantes." (An-Naim, 2007: 21).
\end{abstract}

$7 \S$ Ahora bien, en búsqueda de los dinamismos históricos explicativos es necesario remontarse temporalmente en la indagación, ¿cuándo y cómo nace el paradigma del derecho musulmán y sus estudios en la etapa precolonial? Entre algunos elementos de las posibles respuestas encontramos que un nuevo horizonte jurídico surge con la práctica y los dichos de Mahoma en el siglo VII d.C. Después de la muerte del profeta varias generaciones vivieron sin lo que hoy conocemos como sharía (doctrina, normas religiosas, rituales, morales, jurídicas; que regulan la vida del musulmán). Sin embargo, pronto se iniciará un proceso de canonización (fijación jurídica) que se cierra en el siglo IV aH (siglo

Problemata: R. Intern. Fil. v. 8. n. 1 (2017), p. 324-402

e-ISSN 2236-8612 
$X$ d.C.). Desde la fecha, el jurista se ocupará de glosar la codificación clásica de los manuscritos religioso jurídicos. Con ello, la codificación religioso jurídica de buena parte de la vida de la comunidad musulmana quedaba fijada (y en ocasiones fetichizada). El contenido de estos manuscritos será en adelante objeto de formación para los estudiosos, juristas, jueces y demás profesionales del derecho. La madrassa es la institución educativa donde se transmitirá estos conocimientos y se formará a los discípulos (An-Naim, 2007: 16).

Con todo, para poder dar soluciones prácticas a problemas jurídicos nuevos, los juristas elaboraron un procedimiento racional articulado a los principios religiosos del Corán. Ahora bien, ese esfuerzo (ijtihâd), cuando es colectivo, debe conducir a un consenso (ijmà). El valor de este consenso, aunque no compartido en todas las tradiciones, es también con frecuencia asumido como fuente jurídica (doctrina jurídica). Si se busca que el esfuerzo individual tenga valor jurídico debe seguirse el razonamiento analógico (qiyâs). En otro caso, la conclusión del jurista no tiene otro valor en una mera opinión (ra'y). Las fuentes del contenido jurídico que deben estudiar los fouqahâ están delimitadas (David y Jauffret-Spinosi, 2010: 335-336):

\begin{abstract}
"El contenido jurídico del Corán se encuentra en un cierto número de versículos (llamados por los jurisconsultos islámicos "versículos legales"). La literatura jurídica musulmana distingue los versículos que rigen el estatuto personal (setenta versículos); los versículos relativos al "derecho civil" (setenta versículos); los versículos de carácter [sic] penal (treinta versículos); los versículos que reglamentan el procedimiento judicial (trece versículos); los versículos "constitucionales" (diez versículos); los versículos relativos a la economía y a las finanzas (diez versículos) y finalmente los versículos relativos al "derecho internacional" (veinticinco versículos)" (David y Jauffret-Spinosi, 2010: 335).
\end{abstract}

Dos tradiciones principales, también jurídicas, con sus diferentes escuelas, se han diferenciado en la historia del islam: sunnitas y chiitas. En la tradición sunnita se pueden distinguir diversas corrientes: hanefita, con presencia hoy en Turquía, repúblicas musulmanas exsoviéticas, Jordania, Siria, Afganistán, Pakistán, India, Bengala y Magreb; malaquita, Egipto, Magreb, Sudán, Kuwait, Qatar, Bahréin, Emiratos Árabes Unidos, costa oriental de la península Arábiga, África Occidental; Chafe'ita, Palestina, Adén, sur de la península arábiga, Pakistán, Egipto, Indonesia, Malasia, Ceylán, Filipinas, India y África Oriental; Al hanbalismo, Egipto, Arabia Saudita, Sira e Iraq. En el chiismo se han creado tres grandes tradiciones jurídicas formativas: zaydiles, en Yemen; imanitas, en Iraq, Libia e Irán; y ismailiens, en India, Paquistán y Siria y África de habla inglesa (David y Jauffret-Spinosi, 2010: 334).

La flexibilidad jurídica y respeto al derecho consuetudinario de otros pueblos, en general, le permitió al islam su expansión y también su adaptabilidad a los nuevos tiempos y renovación. 


\begin{abstract}
"La expansión del Islam puede explicarse por su actitud liberal y que no exigía el sacrificio de los modos de vida perpetuados por la costumbre. Si bien ciertas costumbres puedan considerarse ilegítimas, dentro de la óptica del derecho musulmán, existen otras muchas costumbres que existen sin incurrir en esta circunstancia. En esta forma numerosas costumbres tienen una función de complementariedad del derecho musulmán: costumbres relativas al monto o a las modalidades de pago de la dote, costumbres regulando el uso de aguas que circulan entre diferentes propietarios de tierra, costumbres en materia comercial. El derecho musulmán clasifica las acciones del hombre en cinco categorías: obligatorias, recomendadas, indiferentes, culpables, o prohibidas. La costumbre no puede permitir un comportamiento que el derecho declara obligatorio o prohibir un comportamiento que el derecho declara obligatorio; pero puede legítimamente ordenar una conducta que, conforme al sistema de derecho, es solamente aconsejable o permitida, o puede llegar a prohibir una conducta que, según el derecho, considere como culpable o simplemente permitida" (David y Jauffret-Spinosi, 2010: 334).
\end{abstract}

Más allá de que el derecho inspirado en la sharía sigue regulando muchos ámbitos de la vida personal de los musulmanes, así como tiene su influencia la regulación de ciertas relaciones territoriales e internacionales, lo cierto es que no es el hegemónico ni en aquellos pueblos que tienen por religión oficial el islam. El fetiche del derecho occidental lo ha arrinconado a ciertos ámbitos de la esfera familiar (David y Jauffret-Spinosi, 2010: 334).

\title{
Los estudios de derecho en China
}

§8. El sistema jurídico chino, con sus estudios de derecho, afecta directamente a las relaciones de poder de 1.382 millones de personas, con datos de 2016. El derecho, como disciplina universitaria, se introduce en las universidades chinas, recientemente; por primera vez, en 1909, en la universidad de Pequín, que se había creado en 1898. Desde 1949, con la fundación de la República Popular China, hasta 1966 (inicio de la Revolución Cultural), China había creado 227 instituciones de educación superior para unos 130.000 estudiantes. El estudio del derecho ocupaba al $20 \%$ de los estudiantes (15\% de las disciplinas). En 1973, China contaba con apenas cuatro débiles universidades de derecho (la Universidad de Ciencia Política del derecho, de Pequín, y otras tres en el Suroeste, el Este, y Oeste) (Tingting, 2010: 8-9).

Después del desmantelamiento de los estudios de derecho en la Revolución Cultural (1966-1976), en 1978 comienza un proceso de reconstrucción jurídica de la enseñanza. En 2003, a aquellas primeras universidades especializadas en derecho ya se había sumado una más, y 230 facultades o departamentos de derecho en todo el país (David y Jauffret-Spinosi, 2010: 396). A partir de los años 1990, el Estado, con la inversión pública, opta claramente por una educación universitaria popular (de masas) frente a la elitista. 
A título ilustrativo, según el estudio de Mei-Ying Gechlik, Judicial Reform in China: Lessons from Shanghai, (2005) China contaba con unos 300.000 jueces. De ellos, 90.000 tenían título de tercer nivel, y unos 4.000 disponían de formación de maestría o doctorado (Citado en Tingting, 2010: 25). Respecto a su población total universitaria, para 2006 tenía 20 millones de estudiantes universitarios, de los cuales 1.340.000 lo hacían en universidades privadas (6,6\%). De todo ese universo, desde 2005 cada año hay aproximadamente un promedio de 1 millón de alumnos matriculados en las facultades de derecho del país (Tingting, 2010: 10). Con datos de 2013, China contaba ya con aproximadamente unos 230.000 abogados y 20.000 despachos jurídicos (Cheng, 2014: 9). Un elemento que ha estimulado la formación jurídica recientemente ha sido el hecho de levantar, en 1997, la prohibición establecida a inicios de los años cincuenta, para el ejercicio profesional del derecho (autónomo). Hasta esa fecha, la República Popular China los consideraba como trabajadores jurídicos del Estado (David y JauffretSpinosi, 2010: 400).

\$9 En relación con el currículo, las materias de la licenciatura (14) son establecidas a nivel nacional: filosofía del derecho, derecho civil, derecho penal, derecho procesal civil, derecho procesal penal, derecho administrativo, proceso administrativo, historia del sistema jurídico chino, derecho económico, derecho de negocios, derecho de propiedad intelectual, derecho internacional, derecho privado internacional, derecho comercial internacional. El contenido de las mismas es fundamentalmente teórico conceptual, principialista, normativista y jurisprudencial. La práctica jurídica tiene poca relevancia. El derecho natural, una progresiva racionalización del derecho, así como el derecho aplicado son los paradigmas jurídicos dominantes en los estudios de derecho (Tingting, 2010: 14).

En China, respecto a la estructura de los estudios universitarios, después de tres años de enseñanza jurídica, el estudiante obtiene un Master degree en derecho (equivalente al Diploma de Altos Estudios francés) y requiere todavía de tres años adicionales de estudios, y la defensa de una tesis, para poder acceder a un diploma de doctor en derecho (David y Jauffret-Spinosi, 2010: 396). La formación actual del derecho (en su versión codificada y cercana al paradigma occidental) se ha intensificado en las últimas décadas. El contenido de los estudios, así como las investigaciones y publicaciones, se están enfocando fundamentalmente para dar respuesta a las exigencias del fetiche del capital y de las necesidades políticas y administrativas del país.

Publicaciones en derecho en las 15 principales revistas chinas (2009) 


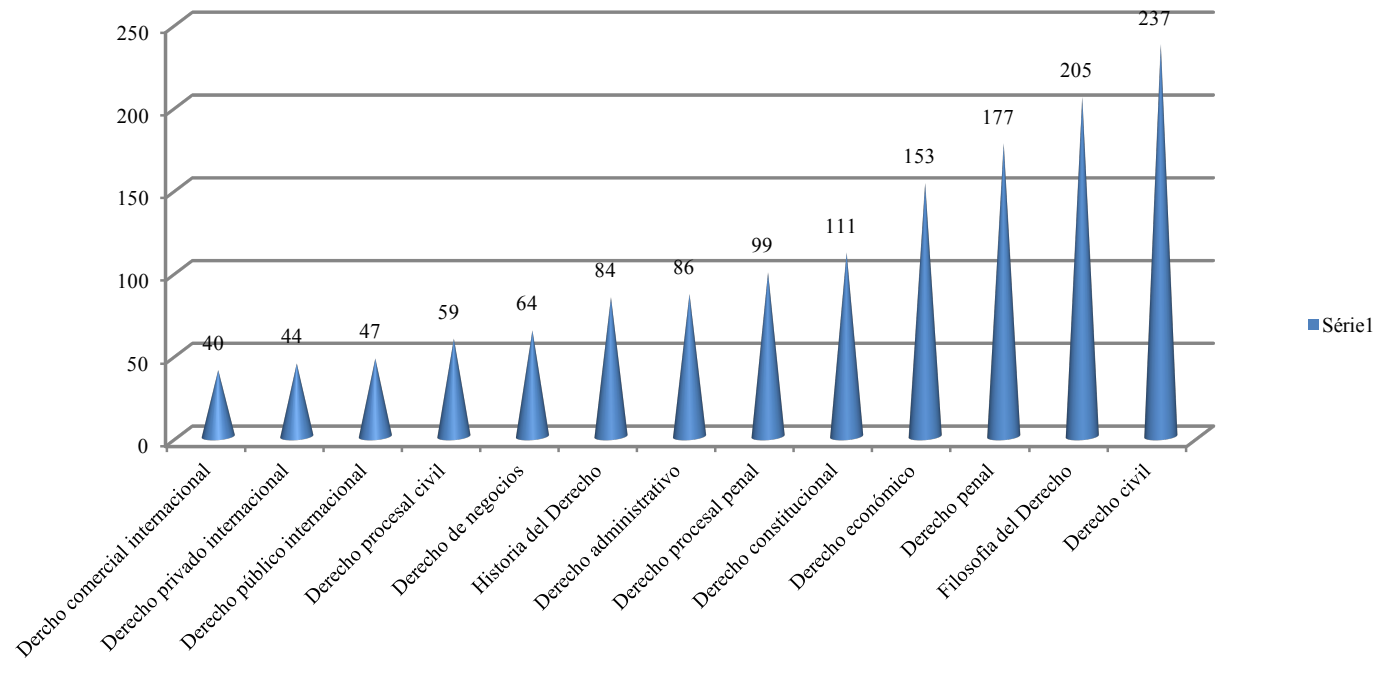

Fuente: Qin Tingting, 2010, p. 30.

En concreto, los campos en los estudios de derecho que están requiriendo mayor atención desde la problemática social son:

$\left.1^{\circ}\right)$ Derecho mercantil y comercial internacional (particularmente contratación internacional, derechos de autor y patentes y marcas);

$2^{\circ}$ ) Estudios sobre el control de constitucionalidad, como medio para racionalizar y mejorar el sistema jurídico en el país;

$3^{\circ}$ ) Estudios sobre el common law y el derecho romano germánico (v.gr. derecho civil francés). Particularmente desde la última década del siglo XX se ha querido modernizar jurídicamente el Estado chino. Para muchos, la tradición confuciona está agotada y sin respuesta para la sociedad compleja de hoy. La modernización se busca en el derecho occidental, sea el common law, el romano germánico, o una mezcla ecléctica de ambos. La recepción de common law está siendo mejor que la tradición de derecho romano, entre otras razones porque es el horizonte en que son formados mayormente los estudiantes que salen al exterior a realizar sus posgrados, así como porque es también el paradigma en que han sido formados buena parte de profesores extranjeros que enseñan en China;

$4^{\circ}$ ) La mediación, arbitraje y conciliación. En las ciudades, y especialmente en el mundo rural, la práctica de la mediación sigue siendo hegemónica sobre la judicialización del derecho (David y Jauffret-Spinosi, 2010: 400-406). 
$5^{\circ}$ ) El derecho penal y administrativo. El campo penal y administrativo, particularmente este último por la necesidad creciente de regular la relación entre el gobierno central y los gobiernos locales. Estos ámbitos, ya en 2005, representaban el 90\% de la actividad procesal de los abogados (Lin, 1999: 2930).

Ahora bien, aparte la hegemonía del contenido de los estudios de derecho en estos ámbitos, generalizados por las urgencias del mercado y su Estado, hay otros necesarios, que se están iniciando tímidamente. Ente ellos:

$\left.1^{\circ}\right)$ El ámbito de la articulación de tres regímenes jurídicos. China tiene que dar respuesta con la formación de su sistema jurídico a tres zonas jurídicas, con autonomía y sistema judicial independiente: a) la zona jurídica continental, en la que se aplica el derecho consuetudinario y legal orientado por los valores morales tradicionales, entre ellos el de la búsqueda de la armonía social, para evitar el conflicto, con la evolución histórica que se ha indicado; b) la zona del Régimen Administrativo Especial de Hong Kong, que por la colonización forma parte de la tradición del common law; c) la zona de Régimen Administrativo Especial de Macao, que por la influencia colonial portuguesa es de tradición jurídica europea continental.

$\left.2^{\circ}\right)$ El ámbito del pluralismo jurídico en áreas nacionales autónomas. Con datos de 2010, China tenía 104,49 millones de personas que viven en un régimen de autonomía (155 áreas autónomas que incluyen 5 regiones autónomas, 30 prefecturas autónomas, 120 condados autónomos; 44 (de 55) naciones minoritarias que han establecido áreas autónomas) (Lin, 1999: 11). A causa de esta diversidad cultural jurídica, Zhu Suli evidencia, desde el mundo rural, el empoderamiento en el ejercicio del pluralismo jurídico, una especie de "evasión del derecho legicéntrico" optando por el derecho consuetudinario.

$\left.3^{\circ}\right)$ Técnica legislativa. El país requiere con urgencias estudios para mejorar su técnica legislativa, dada la debilidad en la tradición jurídico legislativa.

$\left.4^{\circ}\right)$ Hay campos especialmente necesitados de estudios jurídicos y desarrollo normativo, entre ellos: propiedad estatal, soberanía alimentaria, economía reciclable, el derecho medioambiental y la transparencia y participación en la producción normativa.

$\left.5^{\circ}\right)$ derechos humanos. Dado el reciente compromiso explícito constitucional y político por encauzar a China en el marco de los derechos humanos.

$6^{\circ}$ ) Estudios críticos de derecho comparado (superadores del colonialismo ideológico), con un cierto componente de nacionalismo jurídico. Hay sectores que cuestionan las categorías, conceptos y los paradigmas occidentales del derecho romano y common law como inapropiados para dar cuenta de la 
problemática china. Zhu Suli, desde 1990, es uno de los profesores de derecho que ha levantado la bandera de paradigma local; de beber en el saber local (bentuhua). En la misma línea frente a la aceptación colonial y acrítica de paradigmas occidentales de derecho procesal se encuentra Sun Hong Kun. Otros como Guo Zhong reflexionan sobre la relación entre derecho y cultura, como elemento que explica el fracaso en China de algunas modas jurídicas importadas.

$7^{\circ}$ ) Estudios de historia del derecho, para nutrirse de la propia tradición jurídica, particularmente la consuetudinaria, sin complejos.

$8^{\circ}$ ) El derecho de los pies descalzos. Estudio del significado, alcance teórico y desafíos de un modo particular de práctica del derecho, reivindicado por Profesores como Ying Xing, de la universidad de Pequín, y Tiancheng You. Este derecho es ejercido por personas que viven en el mundo rural y que se han formado de modo autodidacta en asuntos jurídicos. Se dedican a defender altruistamente a los campesinos, que no pueden pagar abogados caros y que viven habitualmente en las ciudades. Tienen competencias en materias civiles y administrativas. Competencias que los jueces les reconocen. Su generosidad y cercanía les hacen muy respetados en el mundo rural. Estos abogados de los pies descalzos vuelven al valor tradicional de la reciprocidad y solidaridad, del empoderamiento jurídico popular, en contraposición a la mercantilización, particularmente urbana, de los servicios jurídicos (Piquet, 2008: 19-20).

\$10. Ante esta realidad, cabe preguntarse por qué se están haciendo hegemónico el paradigma jurídico angloamericano y europeo en el ejercicio y en la docencia e investigación en China? ¿Qué alcance tiene esta situación? Para explorar posibles explicaciones, es necesario recurrir a la historia del derecho chino, así como de su impacto en la evolución de la formación jurídica. En unas breves pinceladas históricas, remontándonos desde lo más reciente, encontramos que en 1949, con el triunfo de la República Popular China, se produjo una acogida generalizada de la ley como mediación fundamental del derecho. Un instrumento muy funcional en la transición al comunismo. Esta acogida se hizo - a diferencia de la URSS - en el seno de una fuerte tradición cultural de la moralidad de la praxis, y educación cívica; fuente principal para la evitación y resolución de los conflictos. Con el triunfo de la revolución se pone en marcha el Programa Común que deroga toda la legislación y organización judicial anterior y acomete el plan de una nueva legislación y organización judicial (David y Jauffret-Spinosi, 2010: 391). En 1950 el gobierno central designa una comisión encargada de preparar la nueva codificación del país. Sin embargo, el choque y resistencias de la extendida tradición consuetudinaria no se harían esperar. Entre los años 1952-1953 se produce una fuerte reacción a la codificación y algunos de los presupuestos (dogmas) del paradigma jurídico 
positivista. La reacción fue esencialmente contra: a) la separación del derecho de la política; b) la independencia-neutralidad de los jueces; c) la igualdad de todos ante la ley; d) el formalismo jurídico; e) la irretroactividad de la ley; f) el principio nulla poena sine lege; y g) el principio de la prescripción.

La Constitución de la República Popular China de 1954 vino a apoyar la opción por la hegemonía del derecho, terminando con la reacción (David y Jauffret-Spinosi, 2010: 393). El principio de legalidad parece consolidarse definitivamente en el marco de la constitución de 1975 y la detención y juicio de la "Banda de los Cuatro", por sus implicaciones en la Revolución Cultural. La Constitución de 1978, y el pragmatismo de las reformas iniciadas por Deng Xiao Ping en 1979, "reivindica" de nuevo la importancia del derecho, ahora particularmente como instrumento de seguridad jurídica requerida por las inversiones extranjeras en el marco del proyecto político de construir una sociedad asentada en una "economía de mercado socialista" (David y JauffretSpinosi, 2010: 394). En 1999, la reforma constitucional de la constitución vigente de 1982 (art. 5), define a la República Popular China como un país socialista gobernado por la ley (David y Jauffret-Spinosi, 2010: 397). La reforma constitucional de 2004 introduce como una de las obligaciones de la República la garantía de los derechos humanos. La exigencia de construir el país y ejercer el gobierno en el cauce del derecho (un Estado socialista de derecho) fue el compromiso expreso del décimo Congreso Nacional del Partido Comunista Chino, en 2007.

Visto desde el horizonte jurídico tradicional, hoy el pueblo chino está siendo violentado por oleadas de hordas jurídica "bárbaras". El interés de las corporaciones jurídicas por China ha llevado pronto a firmas anglosajonas a establecerse allá, como por ejemplo China Baker, Clifford, DLA o Linklaters. En 1990 se fusionaron tres firmas jurídicas corporativa, SNR Denton (angloamericana), Fraser Milner Casgrain (canadiense) Salans (europea). De ella surge Denton, una de las diez firmas jurídica más grandes en el ámbito mundial. Por entonces contaban con un ejército de 2.600 abogados. En 1992 se fundaba Dacheng (大成). Esta última, en 20 años se ha convertido en una de las principales firmas jurídicas chinas, con 4000 abogados. En enero de 2015 se produce la fusión de ambas firmas. La nueva corporación es la más grande del mundo, cuenta con un ejército de más de 6.500 abogados junto con otros profesionales del campo. Se extiende en más de 50 países, 120 ciudades. Su objetivo es prestar servicios transcontinentales (globales), desde la doctrina del "policentrismo" jurídico corporativo, en África, Asia y Pacífico, Asia Central, Oriente Medio, Europa, y en países como Estados Unidos, Canadá, Reino Unido, Rusia y China (en cada una de la 34 divisiones administrativas regionales de China). Esta mega corporación jurídica es hoy por hoy la punta de lanza jurídico 
corporativa del fetiche del capital, muy por delante de otras como: Baker \& McKenzie, DLA Piper, Jones Day o Latham \& Watkins (2.000 abogados de media y facturaciones alrededor de los 2.000 millones de dólares anuales) Clifford Chance, Freshfields, Allen \& Overy o Linklaters ${ }^{4}$.

Dentro de las tradiciones del fetichismo jurídico europeo hay una ofensiva de la tradición anglosajona por dominar el mundo. Las firmas jurídicas anglosajonas están dando nuevo impulso a su colonización no solo de China (Asia), sino al interior de Europa, África y América Latina. En España desembarcaron recientemente entre otras las firmas: SJ Berwin (1999), Linklaters (2000), DLA Piper (2001), Hammonds (2003), Lovells y Eversheds (2004), Bird \& Bird (2005) y Howrey y Latham \& Watkins (2007). En África, por ejemplo en Casablanca, en 2004, entra la Gide Loyrette Nouel (quinta en Europa continental) en asociación con Naciri \& Associés. También allá han llegado recientemente otras anglosajonas como Norton Rose Allen \& Overy, Clifford Chance y Norton Rose. En América Latina, un interés particular ha despertado Brasil. Por ejemplo, en Río de Janeiro y Sao Pablo se han asentado firmas angloamericanas como Clifford Chance, Davis Polk, Mayer Brown, Shearman \& Sterling, Simpson Thacher, Skadden, White \& Case, DLA Piper, Jones Day ${ }^{5}$.

Expansión jurídica corporativa de la más grande firma angloamericana y china Denton \& Dacheng (大成), 2015

\footnotetext{
${ }^{4}$ http://www.elconfidencial.com/empresas/2015-01-28/dentons-dacheng-la-firma-de-abogados-masgrande-del-mundo-ya-habla-chino 632247/ 


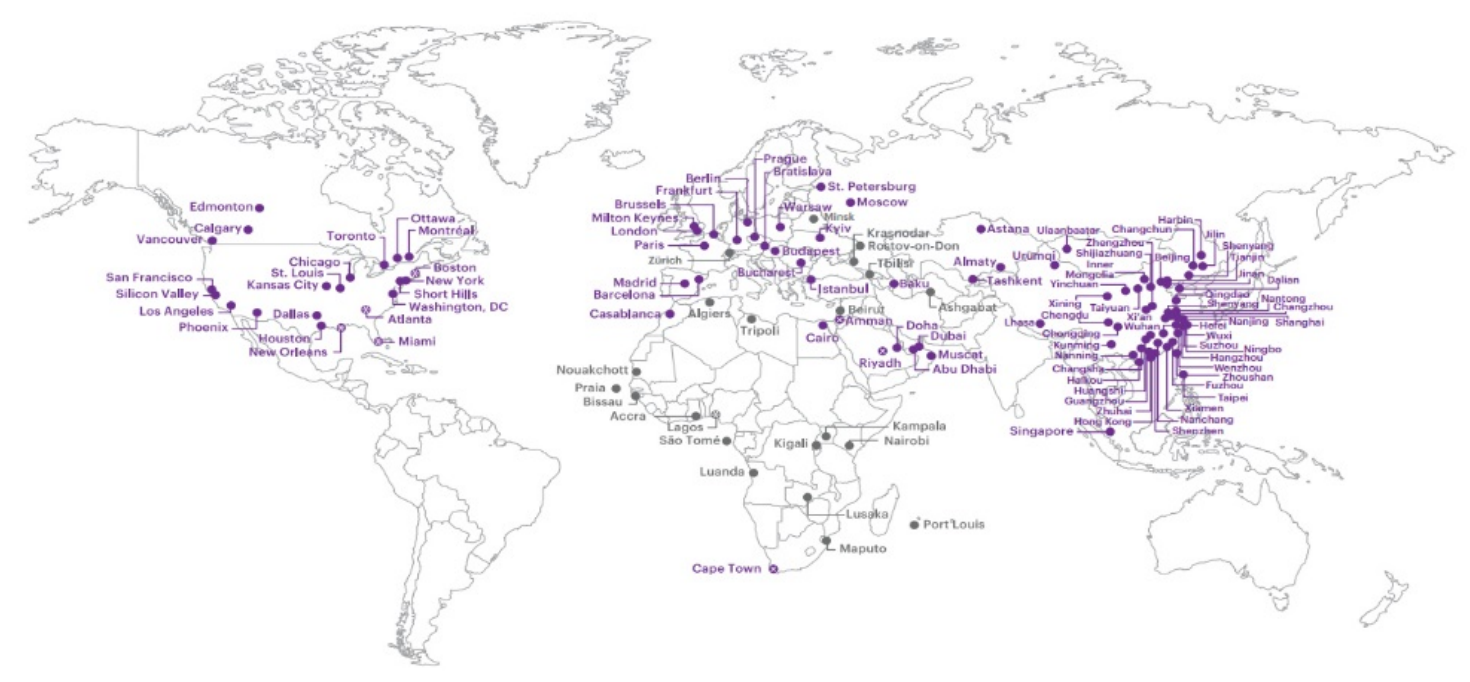

Legend

Offices, associate offices and facilities:

Fuente: El Confidencial, http://www.elconfidencial.com/empresas/2015-01-28/dentons-dacheng-la-firma-de-abogadosmas-grande-del-mundo-ya-habla-chino 632247/

\$11. Pero, ¿por qué la reacción jurídica consuetudinaria de principios de los años cincuenta del siglo XX frente a la acogida de un derecho legislado, al modo europeo del common law o del derecho romano germánico? ¿Había algo detrás que lo explicase? Pues bien, lo que había detrás era nada más y nada menos que el choque de paradigma milenario chino con la importación del fetichismo jurídico del capital. Cuatro décadas antes, al final de la Dinastía Qing (1644-1912 d.C), por las exigencias jurídicas de la extraterritorialidad por parte de las potencias occidentales, tras la derrota de China en las guerras del Opio (1840-1860), la "modernización jurídica" de algunos dirigentes opta por revivir los intentos tradicionales de codificación jurídica, pero ahora "moderna" como sinónimo de europea (v.gr. Código de Comercio, 1903; Código Penal, 1910; Código Civil, 1911). No era propio de la tradición china ni el legicentrismo, ni la codificación, ni la especialización de una profesión jurídica, ni los templos de las facultades de derecho para formar al nuevo sacerdocio jurídico. Es en 1905 cuando aparece por primera vez el término abogado en un texto legal chino, y 1912 cuando se hace la primera reglamentación de la profesión (Cheng, 2014: 3-4). Las dificultades por asumir el nuevo ropaje jurídico se evidencia incluso en el modo de aplicar los nuevos códigos. En muchas ocasiones su aplicación seguía inspirada en el valor tradicional de la equidad, necesario para la armonía social:

"Con frecuencia los jueces chinos seguían sentenciando según los cánones 
confucionistas, que continuaban desplazando las reglas de derecho escritas: los jueces rechazaban desahuciar a un inquilino por ser miserable, cuando éste no hubiere cometido falta alguna, en tanto que el propietario estuviere en ascenso y no necesitare de su propiedad; de la misma forma los jueces proveían plazos de gracia al mutuario, cuando se constituyese en mora, en la medida en la que el mutuante fuese un hombre rico" (David y Jauffret-Spinosi, 2010: 392).

Lo que se encuentra subiendo el río arriba de la historia del derecho chino es que el paradigma hegemónico por cinco mil años ha sido el jurídico consuetudinario. Ciertamente aparecieron codificaciones escritas pero el derecho seguía ejerciéndose fundamentalmente en el ámbito local y en el modo propio de la cosmovisión confuciana. El derecho, con mediación escrita, comienza a aparecer en China, según los datos actuales, dentro de la llamada época de "Los Reinos de los Combatientes" (770-221 a.C.). Del año 536 a.C. se conoce el código penal, escrito en una caldeara de bronce, por Zi Chan, en su cargo de Magistrado en Jefe del Estado de Zheng. También en esa época aparece el código de Fa jing (VI a.C.) por Li Kui del ReinoWei. Este derecho clásico escrito, como primer conjunto de codificación de normas de la China antigua, incluía: a) normas sobre propiedad pública y privada (Dao Fa); b) la estabilidad del Estado y la seguridad personal (Zei Fa); c) el proceso y encarcelamiento (Wang $\mathrm{Fa}$ ); d) investigación y arresto de los presuntos delincuentes (Bu Fa); e) el juego, el fraude, la corrupción, adulterio, etc. (Za Fa); f) condena y complimiento de penas (Ju Fa) (Lin, 2009: 2).

Muchos de los códigos de entonces se perdieron. Hoy solo queda parte del código de la Dinastía de Qin (221-206 a.C.) —el código de la Dinastía T'ang, (siglo VII d.C.) es el más antiguo que se conserva-. En el siglo III a.C., la escuela de los legistas, Han- Fei-tseu entre otros, propone sustituir el gobierno de la virtud por el gobierno de las leyes. Un posicionamiento cercano a la tradición legicéntrica que se desarrollará en Occidente. Se crean algunos códigos, pero limitados al ámbito administrativo y penal, y aplicados según el valor tradicional de la equidad. Sin embargo, la revuelta legista duró poco. En el año 206 a.C., la dinastía Han vuelve al paradigma consuetudinario confuciano de búsqueda de la armonía social antes que el conflicto. Horizonte que dominará hasta el siglo XX (David y Jauffret-Spinosi, 2010: 389-390).

El impacto de estos códigos fue relativo. La realidad es que China ha vivido miles de años sin una especialización en la formación del mundo jurídico, sin la hegemonía de la mediación legicéntrica y sin el sacerdocio de juristas. Cuando los había, la formación y los estudios de los encargados de cumplir con la función jurídica de jueces consistía en un examen, más de carácter literario, cuyo contenido eran los consejos de la sabiduría tradicional (David y JauffretSpinosi, 2010: 389-390. El primer testimonio que se conoce de alguien que "vendía" sus servicios jurídicos es Deng Xi, noble de la nación Zheng de la 
dinastía Chun Qiu (770-475 a.C). Fue duramente criticado por dedicarse a pronunciar "frases equívocas y emitir hipótesis artificiosas". Muchos de los que se dedicaban a asesorar jurídicamente eran llamados, y aún hoy, song gun (ladrones de pleitos) (Cheng, 2014: 1; 3).

Llegados aquí, es necesario preguntarse por el contenido de ese paradigma que le ha permitido a China vivir, no sin derecho, como argumentan algunos autores, sino con un paradigma jurídico consuetudinario. Las principales características que lo han hecho posible son: $1^{a}$ ) la articulación armoniosa del derecho con las leyes de la naturaleza; $2^{a}$ ) la vinculación del moral al derecho; $3^{a}$ ) la articulación del derecho con la tradición ritual cultural; $4^{\mathrm{a}}$ ) la equidad y consideración de las circunstancias subjetivas en la aplicación del derecho; $5^{\text {a }}$ ) unas exigencias particulares para los funcionarios públicos.

La difusión en la región de este paradigma bimilenario, siguiendo a Li Lin, tuvo dos momentos: uno de formación y otro de transformación: a) el proceso de formación se extendió desde la dinastía Qin (221-206 a.C.), y Han Han (202 a.C.- 220 d.C.), hasta las dinastías Sui (581---618 d.C.) y Tang (618---907 d.C.). b) El proceso de transformación comenzó en las dinastías Tang y Song (9601279 d.C) y terminó con la dinastía Qing (1644-1912 d.C). En las dos etapas, el área geográfica ha sido la misma: Asia, la Península Coreana, las islas de Japón, las islas Liuqiu y parte de la península Indo-China. En estos lugares, en el siglo XX tiene lugar un proceso más marcado de adaptación jurídica a la realidad local, sin perder del todo el horizonte jurídico presente por más de dos mil años (Lin, 2009:1-2). Un paradigma que posteriormente extendió su influencia significativamente a toda la llamada Familia Jurídica China (Japón, Corea y Vietnam) (David y Jauffret-Spinosi, 2010: 387; 391).

En el campo jurídico ello ha significado, en términos generales, la hegemonía - sin caer en idealizaciones ni irenismos que niegan la realidad histórica de los conflictos-, del derecho consuetudinario de la conciliación y armonía social frente a la ley (como texto escrito) y la judicialización conflictiva de la vida social. La práctica y la concepción generalizada de la vida en China ha sido, y es aún, vivir en orden (armonía) entre el cielo, la tierra y los hombres, por medio de leyes inmutables. Una concepción dominante que no tuvo perturbadora influencia extranjera hasta el siglo XIX (David y, Jauffret-Spinosi, 2010: 387). La costumbre (praxis) jurídica, en sentido amplio, ha consistido en la búsqueda de la armonía social en cada acto mediante la humildad, la conciliación, el reconocimiento de los errores, la actitud de procura de disolución de los conflictos sociales, etc. Esto forma parte esencial de la axiología consuetudinaria china. La coerción del reproche familiar, social y nacional era suficiente, sin necesidad de llegar a la coacción física de la autoridad comunitaria, siempre presente como posibilidad real. Como hemos señalado, no compartimos la tesis 
de quienes afirman, desde el paradigma etnocéntrico, legicéntrico, legalista y judicializado occidental, que China ha vivido gran parte de su historia sin derecho. Ciertamente en China el recurso a la judicialización del derecho ha sido durante mucho tiempo visto como un fracaso de la virtud personal y comunitaria, de la conciliación, de la vida civilizada. Es algo parecido a lo que ha pasado con el paradigma de la medicina practicada en China. La obligación del médico de familia es que su paciente no se enferme. Si se enferma ya es un fracaso, y en algunos casos se le dejaba de pagar. Por ello, tradicionalmente, el pleito en los estrados de los juzgados se ha asociado como una práctica más propia para extranjeros incivilizados o quienes no procedían con los valores de la civilización china (David y Jauffret-Spinosi 2010: 387).

Sin embargo, también fue una realidad que la buscada y deseada armonía no acababa siempre con los conflictos. De estos, en no pocas ocasiones se convertiría en autor —no solo en actor-, el servidor público encargado de administrar justicia:

\begin{abstract}
"El servidor público a quien incumbía la administración de justicia estaba alejado de los justiciables; no era jurista, y se le reclutaba en principio en otra provincia; ignoraba el dialecto y las costumbres locales; sus subalternos, entre los cuales el justiciable tendría que convivir, estaban corrompidos y hacían alargar el proceso, del cual se nutrían; al justiciable se le sometía a múltiples humillaciones, y el resultado de todo proceso siempre era altamente cuestionable. "De diez razones que pueden explicar la decisión del juez, nueve son desconocidas por el público", proclama la sabiduría popular, mientras que otro adagio dice: "Proceso ganado, dinero perdido". Todo ello ha contribuido a desviar a los chinos de los tribunales, y a obligarlos a resolver sus controversias a través de procedimientos extrajudiciales" (David y Jauffret-Spinosi, 2010: 389).
\end{abstract}

\title{
Los estudios de derecho en India
}

$12 \S$ El sistema jurídico indio, con sus estudios de derecho, afecta directamente a las relaciones de poder de 1.326 millones de personas en 2016. De esta población, unos 14 millones son estudiantes universitarios. Sigue a China y Estados Unidos en número de universitarios, pero es el primer país en instituciones universitarias. Con datos de 2010, había unas 26.455 instituciones de educación superior, 504 universidades, 25.951colleges (D. Gupta y N. Gupta, 2012: 17). De todas ellas, en unas 900 instituciones se ofrecen formación jurídica (Schukoske, 2009: 252). El derecho musulmán se enseña también en las facultades de derecho. Su aplicación en el ámbito de los derechos de las personas alcanza a unos 115 millones (David y Jauffret-Spinosi, 2010: 361). El sistema de los estudios de derecho está organizado en grado y posgrado (maestría y doctorado o Ph.D). Para la obtención del grado (Bachelor of Law, LLB) hay dos caminos: tres años, si el estudiante ya tiene cualquier grado; cinco 
años en los otros casos. La media de edad de los grados en derecho es de 18 y 20 años.

$13 \S$ Respecto a los estudios superiores en derecho, en 2001 la University Grants Commission estableció un modelo de currículo para articular la formación jurídica en todo el país, en coordinación con la autonomía universitaria. En términos generales, los estudiantes de grado tienen que cursar al menos 28 materias de derecho (18 deben ser de contenido jurídico sustantivo obligatorio; cuatro de práctica clínica; seis materias son electivas). Las materias de derecho obligatorias para configurar las 18 son: jurisprudencia, derecho de contratos I, derecho de contratos II, responsabilidad civil y derechos del consumidor, derecho de familia I, derecho de familia II, derecho penal, derecho procesal penal y justicia de menores, derecho constitucional, derecho de propiedad, derecho de la evidencia, derecho procesal civil, lenguaje legal, derecho administrativo, derecho civil, derechos humanos y derecho internacional, mediación y arbitraje, derecho medioambiental, derecho laboral, interpretación legal, ley de tierras (Schukoske, 2009: 265, nota 56).

Los estudios e investigación del derecho después de la independencia, particularmente en las últimas décadas, se han centrado en negocios internacionales, inmigración y derechos humanos. Los estudios de posgrado (maestría) en derecho, según el modelo nacional propuesto por el Curriculum Development Committee $2001^{6}$, son los siguientes: Materias troncales: derecho y la transformación social en India, derecho constitucional en India: los nuevos desafíos; proceso judicial; educación legal y metodología de la investigación; disertación.

Materias opcionales Grupo A. Derecho internacional y organización: derecho, práctica y futuro; desarme y estrategias de paz; derecho humanitario internacional; derecho y diplomacia; derecho del mar; derecho internacional y problemas contemporáneos.

Materias opcionales Grupo B. Derecho penal: proceso penal comparado; tratamiento de los infractores; malas prácticas de la clase privilegiada; drogadicción, justicia penal y derechos humanos; delincuencia juvenil, violencia colectiva.

Materias opciones Grupo C. Derecho de negocios: derecho industrial y propiedad intelectual; regulación legal y empresas económicas; derecho de exportación-importación; derecho bancario; derecho de seguros; derecho corporativo.

\footnotetext{
${ }^{6}$ Curriculum Development Committee, «Law Report.», 2001; http://www.ugc.ac.in/oldpdf/modelcurriculum/law.pdf.
} 
Materias optativas Grupo D. Derecho del trabajo y derecho del capital: derecho de negociación colectiva; derecho de adjudicación industrial; derecho de los servidores públicos; derecho del trabajo agrario; derecho salarial; derecho de la seguridad social.

Materias optativas Grupo E. Derecho medioambiental y orden Legal: medio ambiente y desarrollo; derecho y políticas; derecho y manejo de los recursos; prevención y control de la contaminación; medio ambiente y orden legal internacional; diversidad biológica y orden legal; legislación medioambiental.

Materias optativas Grupo F. Jurisprudencia: proceso judicial comparado; teoría marxista del derecho; jurisprudencia socialista; conceptos de justicia; teoría de los derechos.

Materias optativas Grupo G. Constitución y orden legal: derecho de los medios de comunicación; derecho de las utilidades públicas; derecho de las relaciones financieras de los Estados de la Unión; constitucionalismo (pluralismo y federalismo); derechos humanos.

Materias optativas Grupo $\mathrm{H}$. Crítica feminista del orden Legal: teoría feminista y orden legal; lucha nacionalista e igualdad de género; elementos patriarcales y derecho indio; estándares de justicia de género y derecho internacional; derecho, género y trabajo; planificación poblacional y justicia de género.

Materias optativas Grupo I: Ciencia, tecnología y derecho: derecho, ciencia y tecnología; derecho, ciencia y medicina; la revolución electrónica y el orden legal; tecnología nuclear (dilemas y control legal); epidemiología y salud pública (aspectos de ciencia y tecnología); biotecnología y regulación legal.

Materias optativas Grupo J. Derechos Humanos: concepto y desarrollo de los derechos humanos; derechos humanos y orden internacional; protección e implementación de los derechos humanos en la India; derechos humanos y grupos desaventajados; derecho humanitario internacional y derecho de los refugiados; ciencia, tecnología y derechos Humanos.

Materias optativas Grupo K. Derecho administrativo: proceso administrativo, naturaleza y ámbito; autoridades públicas: obligaciones; autoridades públicas y detentadores del poder (control de la mala administración); derecho de autogobierno local; derecho administrativo comparado.

Como se puede observar, algunas de las perspectivas actuales en los estudios de derecho en la India incursionan en los campos del derecho mundial, derecho global, derecho transnacional, derecho comparado. Siguiendo a William Twining, se pueden diferenciar cuatro ámbitos nuevos en los estudios de derecho que pasa por "indio", en línea con la tendencia mundial: $1^{\circ}$ ) el campo transnacional, fundamentalmente de las relaciones económicas: derecho 
internacional público, derecho regional, derecho comercial internacional, derecho financiero (este incluye la lex mercatoria y el derecho bancario musulmán, derecho financiero musulmán, derecho de Internet, mediación y arbitraje, derecho penal internacional y derecho y desarrollo; $2^{\circ}$ ) el campo nacional de las relaciones: derecho de contratos, derecho de familia, derecho de propiedad intelectual y derecho laboral; $3^{\circ}$ ) el campo de las urgencias sociales: derecho del medio ambiente, derechos y pobreza, derechos humanos y guerra, derecho de seguridad y terrorismo, derechos y migración, derecho al patrimonio intergeneracional de la humanidad, derechos y medios de comunicación y derecho a la salud y pandemias; $4^{\circ}$ ) el campo de la articulación de sistemas jurídicos: la relación del derecho consuetudinario y religioso con los sistemas jurídicos legicéntricos dominante (Schukoske, 2009: 254).

$14 \S$ Intentando profundizar algo más sobre esta descripción, encontramos que los estudios de derecho en India sufren una situación crítica. Los estudios de derecho indio en la actualidad, desde la constitución de 1950, se pueden caracterizar por: $1^{\circ}$ ) la hegemonía de la mediación escrita del texto legal sobre la costumbre jurídica tradicional (legicentrismo). La irracionalidad, anacronismo y desubicación del texto genera tal injusticia en ocasiones que lleva a que la actividad judicial se convierta en creadora de derecho, incluso en contra del derecho escrito, resolviendo en atención a la justicia y la equidad del caso concreto; $2^{\circ}$ ) la hegemonía colonial del paradigma de la tradición del common law británico (David y Jauffret-Spinosi, 2010: 384); $3^{\circ}$ ) escasa investigación en el campo jurídico; $4^{\circ}$ ) la metodología poco crítica y marcada por el caso y la litigación.

Entre algunas de las causas del estado crítico de los estudios de derecho se pueden identificar: a) las dificultades laborales del profesor universitario particularmente en el campo del derecho. Dadas las condiciones laborales, muchos de los docentes trabajan medio tiempo o tiempo parcial. Los salarios son bajos, particularmente para quienes enseñan derecho en la India. Los salarios más elevados así como el mejor estatus social de barrister, con derecho a intervenir ante los tribunales, tradicionalmente era reservado para quienes estudiaban en el Reino Unido. Aún hoy no abundan los profesores docentes a tiempo completo que hagan carrera académica; b) el peso excesivo a la docencia. Los profesores tienen elevados números de alumnos, y su tiempo se concentra en la docencia; c) la falta de formación teórica y metodológica para la investigación jurídica crítica. La investigación casuística no termina de acoger la metodología de la resolución de problemas de la comunidad; d) direccionamiento de la formación jurídica fundamentalmente para la práctica litigiosa; e) la limitada formación de los estudiantes en la carrera (programas de dos o tres años); f) gran parte de los estudios de derecho se aíslan o circunscriben en lo referente 
al proceso, marginando la realidad y necesidades sociales (Dasgupta, 2009: 432-433).

$15 \S$ Pero ¿cómo se ha llegado a este punto crítico? Buscando respuestas es interesante notar que después de la independencia el estado federal indio constituyó los estados federales de acuerdo a la identidad y lengua de cada uno de ellos (David y Jauffret-Spinosi, 2010: 378), y sobre ellos articuló la continuidad del paradigma jurídico de la colonia:

\begin{abstract}
"Los juristas indios estiman que el procedimiento inglés es el medio para la consecución de una solución justa en cuanto al fondo de la controversia. La psicología de los abogados y jueces, es similar por otra parte, al de los abogados y jueces ingleses, y el mismo prestigio está asociado a la función judicial. La misma eminente función se atribuye, en India como en Inglaterra, al Poder Judicial que implica la negación de una distinción entre derecho público y derecho privado: las cortes deben ejercer un control general sobre toda controversia, sin que deba distinguirse si el autor de la trasgresión es un particular o un servidor público" (David y Jauffret-Spinosi, 2010: 377).
\end{abstract}

En la tarea de colonizar jurídicamente el pensamiento y la ejecución de las acciones, las universidades van a jugar un papel central para la extensión de paradigma jurídico del common law. Al inicio de la independencia había en la India 20 universidades y 591 colleges, con una población universitaria de 200.000 alumnos. Este país, que es hoy el primer país del mundo en instituciones de educación superior, asumió que para el nuevo camino político necesitaría otra formación universitaria y jurídica que extendiese y mejorase la formación superior -todavía hoy dos terceras partes de las instituciones ofrecen una formación por debajo de los estándares esperados-. En 1948, para dar respuesta a la demanda social de calidad, se creó la primera comisión nacional. Sus recomendaciones sobre la cualificación de los profesores como docentes investigadores y la necesidad de una formación crítica del pensamiento de los alumnos no tuvieron eco. Otros intentos superficiales de reforma fueron propuestos en la década de los 60. Sus deficiencias fueron evidenciadas, entre otros, por juristas indios como Upendra Baxi, profesor de la Universidad de Delhi. Sus aportes abren la discusión hacia la necesidad de orientar los estudios jurídicos, crítica e interdisciplinarmente (integrando la ciencia política, la historia, las relaciones internacionales y la sociología) y apegados a la realidad local y comunitaria. Posteriores intentos han habido para mejorar el curriculum como el acometido en 2001 por el Curriculum Development Committee (Dasgupta, 2009: 432-433). Sin embargo, más allá de los deseos y parciales mejoras, el hecho es que la mayoría de los estudiantes de derecho son de la clase alta y clase media. Pocos estudiantes de la clase pobre o baja acceden a este tipo de sacerdocio jurídico, y los que lo hacen es con beca. El destino laboral de ellos, aproximadamente en un $90 \%$, es trabajar para una compañía nacional o internacional ( $v$.gr. es el caso de los estudiantes de la West Bengal National University of Juridical Sciences) (Dasgupta, 2009: 443). Quienes se orientan por la vida académica, por razón del sistema, son muchas veces profesores casi con la misma edad que los alumnos. Su débil formación 
y escasa madurez, aparte de la precariedad laboral y de recursos, repercute en la calidad de los estudios de derecho (Dasgupta, 2009: 444).

$16 \S$ Sin embargo, la pregunta persiste: ¿por qué son los estudios del derecho lo que son en la India hoy día? Tal vez no encontremos respuesta plena en la evolución de los acontecimientos en la India desde la segunda mitad del siglo XX. ¿Tendrá que ver algo el paradigma de estudios de derecho antes de la independencia, bajo el dominio colonial británico? Pareciera que sí. Realmente la independencia y la constitución de 1950, como hemos señalado, no significó ruptura con el horizonte jurídico del common law sino la continuidad y el reforzamiento del horizonte paradigma jurídico colonial.

Para que esto fuese posible, el paradigma del derecho tradicional de la India tuvo que ser sometido. Buena parte de las nociones, conceptos y categorías jurídicas tradicionales indias fueron eliminados. El imperio británico le encorsetó un traje jurídico al pueblo de la India del que aún no se ha liberado. Sin embargo ese modo de vivir jurídico no siempre fue así. La imposición comenzó con la colonización.

La colonización ideológico jurídica fue una pieza clave para la dominación cognitiva, política y cultural de la India. En este sentido, el imperio británico impuso a la India el horizonte del derecho territorial importado (lex loci) frente al derecho de sus constelaciones religiosas (hindúes, musulmanes, cristianos, judíos, parsis, etc.) y al derecho de la tribu propio de la tradición india milenaria. Las exigencias del mercado capitalista británico urgían mayor uniformidad abstracta en la normativa jurídica. Los sistemas jurídicos tradiciones hindúes y musulmanes no eran funcionales para la creciente velocidad de las transacciones comerciales que generaba la nueva apertura mercantil de la India a Occidente (David y Jauffret-Spinosi, 2010: 371). No hubo interés real por el conocimiento intercultural de parte de la colonia. Así, por ejemplo, solo se tradujeron un tercio de los dharmasastra (ciencia de la conducción moral y jurídica de la vida). Con esta mutilación, ya resultaba imposible pretender el desarrollo de una regulación, propia y originaria, de la complejidad de las nuevas relaciones sociales. La tradición jurídica india, ocultada, silenciada y mutilada no podía dar respuesta completa y coherente a las nuevas exigencias de la aceleración comercial impuesta. Tampoco hubo un mayor interés en encontrar los términos apropiados para la correcta traducción de muchos conceptos hindúes (David y Jauffret-Spinosi, 2010: 363). La tradición jurídica hindú quedó primero deformada, para posteriormente ser reducida al gueto del ámbito jurídico familiar ( $v$.gr. sucesiones, matrimonio, adopción, sistema castas, etc.).

"El reemplazo de los derechos hindú e islámico, por el derecho inglés, se produjo por la vía de la competencia. Así, en las jurisdicciones de Bombay, Calcuta y Madrás se convino que el derecho inglés se aplicara en las relaciones entre europeos y que el derecho hindú de los contratos, debía ser aplicado cuando la parte demanda fuere hindú. Sin embargo, este principio no fue observado en la práctica. Por un lado, las partes frecuentemente convenían someter sus relaciones contractuales, al derecho inglés que contenía mayor certeza; por otra parte, la interpretación del derecho hindú, se hacía conforme al espíritu inglés, por jueces que resultaban totalmente extraños a la civilización de la India" (David y Jauffret-Spinosi, 2010: 365). 
En 1772, dada la imposibilidad real de completar el pleno dominio jurídico, entre otras causas, por la lejanía en especial del mundo rural y la extensión y grado de diversidad de los pueblos en la India, el colonizador se ve forzado a aceptar (v.gr. gobierno de Warren Hastings en 1772) la competencia jurídica del paradigma tradicional hindú y musulmán para asuntos relacionados con los estados de la vida personal y familiar (v.gr. sucesiones, matrimonio, castas, usos o instituciones religiosas). Cuando no había norma prevista en las tradiciones jurídicas, se aplicaba según la costumbre y el principio de justicia, equidad y buena conciencia.

Ahora bien, en las ciudades más pobladas era otra cosa. En 1781 se extiende la competencia de las cortes judiciales a todos los asuntos jurídicos, independientemente de la religión y tradición cultural (aunque en los asuntos personales podían aplicar las leyes y costumbres de las propias tradiciones religiosas si es que el asunto afectaba, por ejemplo, a personas hindúes o musulmanas). Las ciudades como Bombay, Calcuta y Madrás se convirtieron en centros de esta expansión del paradigma jurídico colonial del capital (David y Jauffret-Spinosi, 2010: 372).

En 1788, Sir William Johns Lord Cornwallis pone en marcha uno de los primeros intentos de codificación del derecho de negocios y de sucesiones, sobre el modelo de los "inestimables Pandectas de Justiniano" (David y JauffretSpinosi, 2010: 362, nota 11). Un proceso de reforzamiento colonial que en 1833 se incrementará, ahora ya, con las primeras compilaciones normativas. La Charter Act de ese año inicia un proceso de "compilación" de la legislación y jurisprudencia, fundamentalmente de la common law, todo ello en detrimento de la codificación del derecho hindú o musulmán, pese a algunos intentos. Desde mediados del siglo XIX se refuerza el proceso de codificación colonial. Por ejemplo, los códigos penales y civiles normados en la India en este periodo muestran evidencias de los códigos civiles y penales de algunos estados de EE.UU., como Luisiana o Nueva York. La codificación tenía una doble función: a) contribuir a evitar y reprimir revueltas ( $v . g r$. sipahis, 1857); b) responder a las exigencias mercantiles del comercio Occidental (David y Jauffret-Spinosi, 2010: 372). En 1861 se impone que los jueces en la India deben ser profesionales formados en el common law y la nueva codificación. Sin embargo, las revueltas contra este exacerbado colonialismo codificador no tardaron en manifestarse, deteniendo algo la velocidad de su avance (David y Jauffret-Spinosi, 2010: 372).

A pesar de ello, las victorias del fetiche jurídico del capital eran constantes. Un ejemplo dramático fueron las envestidas que se le dio, para quebrarla, a una de las instituciones tradicionales más arraigadas en la India: la comunidad de bienes familiares. Dos fuertes golpes recibió desde el colonialismo jurídico británico. En 1930, la Hindu Gains of Learning Act pone fin a la práctica 
tradicional de entregar a la comunidad los salarios de los miembros obtenidos por una mejor formación de aquellos gracias a la ayuda de esta. En 1937, la Hindu Women's Property Act introduce los derechos sucesorios de la viuda respecto a los bienes del marido, en igualdad con los hijos, y los mismos derechos del marido respecto a los bienes de la comunidad avance (David y Jauffret-Spinosi, 2010: 366).

$17 \S$ Ascendiendo de la época colonial, dando un paso más adelante en la investigación, esto es, un pasito más atrás en la historia, es necesario preguntarse, ¿qué paradigma de derecho tenía la India antes de la invasión imperial británica con su common law en el siglo XVIII?, ¿en qué tipo de estudios de derecho se formaba en la India antes del dominio colonial?, ¿queda vivo algo de aquella tradición jurídica?

Pues bien, antes del colonialismo británico había derecho en la India. Hubo derecho vivo por miles de años. Un paradigma intercultural con sus aciertos y contradicciones, como todos. Así, como en el caso de China, la traición cultural jurídica de la India fue fundamentalmente consuetudinaria. La costumbre jurídico-religiosa era la regla de acción, resolución de conflictos y sanción. Costumbre alimentada en la razón, la equidad y la armonía con el universo. En el caso del pueblo tamil, del sur de la India, el derecho consuetudinario, sin especialistas, conocido oralmente por toda la comunidad, fue hegemónico en la India hasta el siglo XIX, cuando fue segado por el imperio avance (David y Jauffret-Spinosi, 2010: 360).

Una de las instituciones jurídicas propias del derecho tradicional hindú, como hemos indicado, es la comunidad de bienes familiares. Esta cumple una función central en el aseguramiento de las condiciones materiales de vida de la familia. Se legitima religiosamente en la obligación que tienen los descendientes hombres de entregar ofrendas a sus antecesores por tres generaciones. Esta obligación es también el origen de la regulación jurídica tanto del matrimonio como la filiación y adopción así como de la sucesión avance (David y JauffretSpinosi, 2010: 362).

\footnotetext{
"Esta comunidad de bienes familiares, está compuesta por un padre de familia y por todos los descendientes varones en línea recta consanguínea paterna, hasta la tercera generación. Cuando el padre de familia fallece, los descendientes varones de la cuarta generación ascienden a la comunidad, y el de mayor edad entre los miembros de esa comunidad se convierte en el pater familias. Los miembros de la comunidad están perfectamente legitimados a separarse y crear nuevas comunidades. Los bienes familiares comunes incluyen los bienes ancestrales, las adquisiciones efectuadas con ayuda de sus bienes, las adquisiciones hechas conjuntamente por miembros de la comunidad y los bienes propios entregados voluntariamente a la comunidad. Los bienes comunes son administrados por el líder de la comunidad." (David y Jauffret-Spinosi, 2010: 366).
} 
En la India, aproximadamente en torno al siglo VI a.C, algunas de las reglas consuetudinarias comenzaron a ponerse por escrito. Aparecieron las satras (ciencias) de la vida: a) el dharma-sastra (ciencia de conducción de la vida moral y jurídica); b) artha-sastra (ciencia de conducción de la política, gobierno y comercio); c) kama-sastra (ciencia de la conducción de la vida corporal). Luego de un largo periodo, hacia el siglo $\mathrm{VI}$ d.C. se desarrolla un proceso de glosa y comentario de los dharmasastra llamados los nibandhas. Un proceso que se extiende en el tiempo por más de mil años, hasta el siglo XVII. Durante esta etapa, la costumbre debía seguirse si es generalizada en una región o casta, incluso contra legem o praeter legem. Cuando la costumbre no daba respuesta para aclarar cómo conducirse moral y jurídicamente ante un hecho o acontecimiento, se recurría al dharmasastra (David y Jauffret-Spinosi, 2010: 358). Entre partes, sometidas a costumbres diferentes, se aplica el dharmasastra como derecho común (David y Jauffret-Spinosi 2010: 359).

\section{Los estudios de derecho en América Latina y el Caribe}

$18 \S$ El sistema jurídico de América Latina y el Caribe, con sus estudios de derecho, afecta directamente a las relaciones de empoderamiento de 634.000 millones de habitantes, con datos de 2016. A modo ilustrativo vamos a elegir tres países para mostrar el estado de los estudios del derecho: México (128 millones), en Norteamérica; Brasil (209 millones), por las dimensiones de su población y tradición portuguesa, y Argentina (43,8 millones) en Sudamérica.

En México, la enseñanza del derecho se realiza en universidades públicas e instituciones particulares. La carrera de derecho es de las que más demandan los estudiantes. En 2013 había 1.426 instituciones particulares, con revalidación nacional de estudios. Muchas de ellas respondían a la creciente demanda y oferta de los estudios de derecho. Ya en 2012, los alumnos matriculados en derecho en las instituciones del país eran 293. 174, según la Subsecretaría de Educación Superior (SEP). Sin embargo el número de egresados era bajo, 43.461 (Turull i Rubinat y Rovira, 2010).

El currículo de los estudios de derecho mexicano refleja una gran heterogeneidad. Muchas de las instituciones responden a estándares que hemos visto en otros lugares. Tomando como ejemplo la UNAM, el currículo se organiza en ocho semestres (450 créditos en total). $1^{\circ}$ Semestre: derecho romano I, historia del derecho mexicano, introducción al estudio del derecho, sociología general y jurídica, teoría general del estado, derechos humanos, inglés I; $2^{\circ}$ Semestre: acto jurídico y personas, derecho romano II, metodología jurídica, teoría del derecho, teoría de la ley penal y del delito, teoría de la constitución, inglés II; $3^{\circ}$ Semestre: bienes y derechos reales, delitos en particular, derecho 
constitucional, sistemas jurídicos, teoría del proceso, teoría económica, inglés III; $4^{\circ}$ Semestre: derecho procesal civil, derecho administrativo, derecho económico, garantías constitucionales, obligaciones, sociedades mercantiles, inglés IV; $5^{\circ}$ Semestre: contratos civiles, derecho procesal penal, derecho internacional público, derecho administrativo II, régimen jurídico del comercio exterior, título y operaciones de crédito, inglés $\mathrm{V} ; 6^{\circ}$ Semestre: contratos mercantiles, derecho fiscal, derecho internacional privado I, derecho individual del trabajo, filosofía del derecho, derecho familiar, inglés VI; $7^{\circ}$ Semestre: amparo, derecho fiscal II, derecho bancario y bursátil, derecho internacional privado II, derecho colectivo y procesal del trabajo, derecho sucesorio, cómputo (requisito de titulación); $8^{\circ}$ Semestre: derecho agrario, seguridad social, argumentación Jurídica; lógica jurídica, juicios orales en materia civil, juicios orales en materia penal, curso permanente de ética (requisito de titulación) (Turull i Rubinat y roviera, 2010: 207).

Por otro lado, el Centro de Investigaciones y Docencia Económicas (CIDE), un centro público de gran reconocimiento social, también forma en derecho. Pretende cambiar la tendencia formativa e investigadora en el ámbito jurídico. Busca que la formación e investigación deje de ser dogmático exegética del texto normativo y se vuelva más asentada en los problemas jurídicos. Metodológicamente acoge el estudio de caso, propio de la tradición del common law, como recurso para el cambio. A diferencia de otras muchas instituciones que conforman las mallas sumando materias como un collage, el CIDE articula las materias según campos o ámbitos: derecho civil, derecho mercantil, derecho constitucional, derecho administrativo, derecho procesal, derecho penal, derecho internacional, pensamiento jurídico, economía, métodos cuantitativos, económicos y de negociación aplicados al derecho, prácticas profesionales, seminario de titulación, especialización, historia universal de México, y escritura argumentativa (Turull i Rubinat y Rovira, 2010: 208).

Por su parte, Brasil cuenta aproximadamente con 1.000.000 de estudiantes de derecho. En 2011 el número era de 723 mil. La enseñanza del derecho, en cuanto saber- conocer, se imparte en tres tipos de instituciones públicas (federales o estadales) o privadas (estas las más numerosas): universidades (públicas, 102; privadas 88), centros universitarios y facultades autónomas. Con datos oficiales censales de 2011, había entonces más de 847 instituciones de enseñanza superior registradas, que en total ofrecian 1.121 grados de derecho. La carrera se organiza en diez semestres (con al menos 3.700 horas de clase presencial) (Turull i Rubinat y Rovira, 2010: 65).

En el caso brasileño, los objetivos de la formación jurídica queda explicitados en la Resolución del Consejo Nacional de Educación Superior de 2004 en la materia: «una formación sólida general, humanística y axiológica, capacidad de análisis, dominio de los conceptos y de la terminología jurídica, la 
argumentación correcta, la interpretación y apreciación de los fenómenos jurídicos y sociales, junto con un capacidad reflexiva y visión crítica que fomenta la capacidad y la aptitud para el aprendizaje autónomo y dinámico, indispensable para el ejercicio de la ciencia del derecho, de la prestación de la justicia y el desarrollo de la ciudadanía».

La estructuración curricular de los contenidos queda regulada a nivel nacional en torno a tres ejes. Siguiendo a Argelia Queralt y Antonio Maués estos ejes son:

\begin{abstract}
"1 Eje de formación fundamental. Tiene como objetivo adentrar al estudiante en el mundo del derecho, estableciendo el marco de relaciones de esta disciplina con otras áreas de conocimiento; se incorporarán, entre otros, contenidos esenciales de la antropología, ciencias políticas, economía, ética, filosofía, historia, psicología y sociología;

$2^{\circ}$ Eje de la formación profesional. No solo debe ofrecerse un enfoque dogmático de las materias estudiadas, sino, además, el conocimiento de la vertiente práctica. Se estudiarán las peculiaridades de las diferentes ramas del derecho, de cualquier naturaleza, de forma sistemática y contextualizada de acuerdo con la evolución de la ciencia del derecho. Asimismo, se analizará su aplicación a las relaciones sociales, económicas, políticas y culturales de Brasil y de sus relaciones internacionales. En este eje, las materias que necesariamente deben ofrecerse son derecho constitucional; derecho administrativo; derecho tributario; derecho penal; derecho civil; derecho comercial; derecho laboral; derecho internacional, y derecho procesal.

e) Eje de formación práctica. Su finalidad es integrar la práctica y los contenidos teóricos ya adquiridos en los ejes anteriores. Esta formación práctica se llevará a cabo especialmente a través del estágio superviosionado, el trabajo de fin de grado y las actividades complementarias" (Turull i Rubinat y Rovira, 2010: 65).
\end{abstract}

En relación con la metodología y la pedagogía de la enseñanza del derecho, la regulación estatal establece los siguientes objetivos, según la sistematización de Argelia Queralt y Antonio Maués: lectura, comprensión y elaboración de textos, actos o documentos jurídicos, normativos y jurisprudenciales; interpretación y aplicación del derecho; búsqueda y correcta utilización de legislación, jurisprudencia, doctrina y cualesquiera otras fuentes del derecho; correcta actuación tecnicojurídica en las distintas instancias administrativas y judiciales, y el debido conocimiento de procesos, actos y procedimientos; uso correcto de la terminología legal y de la ciencia jurídica; uso del razonamiento jurídico, la argumentación, la persuasión y el pensamiento crítico; valoración y toma de decisiones; dominio de las tecnologías y de los métodos para el entendimiento y la aplicación del derecho (Turull i Rubinat y Rovira, 2010: 68-69).

Por último, en Argentina las universidades son también el lugar fundamental en el que se ha recluido la formación de los "juristas". El derecho se enseña aproximadamente en el $64 \%$ de las universidades. Entre las privadas la oferta de la carrera de derecho llega al $73 \%$, y en las públicas al $54 \%$. El número 
total de alumnos es mayor en las públicas por la gratuidad. La carga horaria mínima es de 2.600 horas, en una duración mínima de cuatro añoslbid. Es la carrera con el mayor número de alumnos. Ya en 2009 tenía 202.991. Las facultades de derecho públicas según el número de alumnos son la Universidad Nacional de Buenos Aires (UBA), la Universidad Nacional de Lomas de Zamora, y la Universidad Nacional de Córdoba. Entre las privadas, destaca Universidad Católica de Salta (Turull i Rubinat et al., 2010: 37).

Tomando como ejemplo la Universidad de Buenos Aires, en el ciclo básico común se imparten seis materias obligatorias: 1. Introducción al pensamiento científico; 2. Introducción al conocimiento de la sociedad y el estado; 3 . Ciencia política; 4. Derecho; 5. Economía; 6. Sociología.

Al ciclo básico le sucede el ciclo profesional común, con catorce asignaturas obligatorias: 1. Teoría general del derecho; 2 . Teoría del estado; 3. Derechos humanos y garantías; 4. Elementos de derecho constitucional; 5. Elementos derecho civil. Parte general; 6 . Obligaciones civiles y comerciales; 7. Contratos civiles y comerciales; 8. Elementos de derecho procesal civil y comercial; 9. Elementos de derecho penal y de procesal penal; 10. Elementos de derechos reales; 11. Elementos de derecho administrativo; 12. Elementos de derecho del trabajo y de la segundad social; 13. Elementos de derecho comercial; 14. Elementos de análisis económico y financiero. Terminado este ciclo el alumno obtiene el grado de bachiller en derecho.

El ciclo profesional orientado (CPO) sigue al ciclo profesional común. Este puede enfocarse en siete direcciones: 1. Derecho público, con dos suborientaciones: derecho administrativo y derecho internacional público; 2. Derecho privado; 3. Derecho penal; 4. Derecho empresarial; 5. Derecho del trabajo y de la seguridad social; 6. Derecho tributario; 7. Derecho notarial, registral e inmobiliario. En este ciclo hay cinco asignaturas obligatorias para todas sus orientaciones: 1. Derecho internacional público; 2. Sociedades civiles y comerciales; 3. Derecho de familia y sucesiones; 4. Finanzas públicas y derecho tributario; 5. Derecho internacional privado (Turull i Rubinat y Rovira, 2010: 40-41).

$19 \S$ Haciendo una caracterización general de los estudios de derecho hegemónicos en América Latina se encuentran elementos comunes con el resto del mundo: son expresión y funcionales a la ideología del fetiche jurídico del capital y al sistema de relaciones sociales del imperialismo colonial capitalista (Montoya, 2005: 36-40): 1) formalistas; 2) dogmáticos, acríticos y de totalidad cerrada, sin lagunas, contradicciones o carencias; 3) aislados de la realidad social; descontextualizada e irrelevante ante las necesidades de interés público así como de justicia social; 4) carentes de interdisciplinariedad. El derecho se considera como campo autónomo autárquico respecto del campo político, 
económico; sociológico, axiológico, antropológico, psicológico, etc.; 5) carentes de interculturalidad; 6) centrados en el núcleo duro del derecho privado (contractual); funcionales a las demandas del mercado del capital y a las demandas de las instituciones públicas, que en general son serviles al capital y a las exigencias de dominación del centralismo del poder político; 7) colonialmente reproductores, con escasa investigación académica de calidad; 8) dirigidos por personal académico que reproducen las limitaciones señaladas, dada la precariedad salarial, inestabilidad profesional de la carrera académica; 9) estudios de derecho impartidos por universidades como organizaciones no profesionales que pretenden la producción científica (Witker ve un contraste con las facultades de derechos de las universidades europeas, que considera organizaciones profesionales para la producción científica); 10) estudios de derecho elitistas; los estudios de derecho en América Latina sigue siendo para una élite social; 11) estudios de derecho mayoritariamente privatizados; en América Latina sigue siendo de mayor peso la enseñanza privada universitaria que la pública; 12) metodológicamente se investiga y estudia el derecho fundamentalmente como deducción jurídica, análisis de texto normativa, y glosa legal y jurisprudencial; 13) currículos en derecho diseñados para dar cobertura disciplinar a todos los códigos; con ausencias de cuestionamientos éticos sobre los fines de la aplicación del derecho; 14) marginalidad de los estudios de derecho comprometidos con la función social transformadora (revolucionaria) del derecho; 15) estudios de derecho impartidos con una docencia y pedagogía sacralizante de la autoridad irrefutable; así como ritualista, fetichizada y fetichizante de la norma al servicio de la jerarquía social del dominio de clase (Montoya, 2005: 29; 31-36; 40).

$20 \S$ Ahora bien, ante este panorama hay que preguntarse por sus causas. En algunas de ellas encontramos que el paradigma de derecho romano germánico, positivista, voluntarista y civilista, de inspiración francesa - el fetiche de la burguesía ilustrada capitalista - se fue acogiendo en América Latina en su proceso de independencia política de España y Portugal en el siglo XIX, no sin resistencias de la tradición canónica católica (Leguizamón 2005: 150). Las exigencias de la complejidad del capitalismo imperialista industrial necesitaban desembarazarse del teocentrismo y de cualquier límite del iusnaturalismo, incluso racionalista. El control de la formación de los abogados y los planes de estudio se convirtió en un elemento fundamental para las nuevas clases burguesas, como lo había sido para la colonia imperial española y portuguesa. El poder del derecho no se les podía escapar para ser apropiado por el pueblo. Controlando a los abogados controlaban las instituciones y todo el sistema (Leguizamón 2005: 151). A modo de ejemplo, en Colombia ya Francisco de Paula Santander, en 1826, modifica el plan de estudios de derecho, orientándolo 
hacia el liberalismo y el "utilitarismo" de Jeremías Bentham. El Bachillerato en derecho exigía un previo Bachillerato en Filosofía (orientación iusnaturalista teológico-racionalista). Las materias que se enseñan, propiamente en la formación jurídica eran: legislación universal; derecho constitucional; ciencia administrativa y estadística; derecho civil romano y patrio; derecho público eclesiástico (canónico); economía política y estadística de Colombia; derecho internacional. Sin embargo, el liberalismo y el utilitarismo encontrarán resistencias en la Iglesia Católica que presionará para su eliminación desde 1842. Materias como la legislación universal, el derecho constitucional y el derecho administrativo fueron eliminadas de los planes de estudios por peligrosas, y sustituidas por otras materias como derecho comercial, economía política, derecho procesal civil y penal. También desde ese año 1842 los abogados podrán litigar como profesionales. En las universidades ya no se formarán solo a funcionarios de las instituciones estatales (Leguizamón 2005: 152). También en el caso de Brasil se evidencia la colonización liberal positivista en la enseñanza del derecho. La formalización de los estudios de derecho en Brasil, en 1827, con la creación de dos facultades, reflejan claramente la respuesta liberal a las exigencias del mercando. Como contenido en la estructura curricular se establecía, en los dos últimos años de la formación, derecho civil y comercial (en el cuarto año) y práctica procesal y economía política (quinto año). El derecho eclesiástico se mantuvo, se convirtió en optativa en 1879 y se elimina finalmente de los planes de estudio en 1895 (Martinez, 2011: 3; 5).

$21 \S$ Ahora bien, qué había antes de que resultase hegemónico el fetiche jurídico del capital en el siglo XIX en América Latina? Pues bien, el paradigma jurídico dominante anterior, desde el siglo $\mathrm{XV}$, fue el impuesto por las potencias coloniales españolas y portuguesas. El sistema mundo jurídico había comenzado con el "encubrimiento del otro" de la conquista española, en palabras de $\mathrm{E}$. Dussel. Con la invasión imperial portuguesa y española dio comienzo en nuestra América la hegemonía, a sangre y fuego, del paradigma jurídico imperial romano germánico. El imperialismo jurídico también lo fue de los planes de estudio de derecho.

\section{Dinamismo histórico hegemónico estudios de derecho s. XV-XVII}




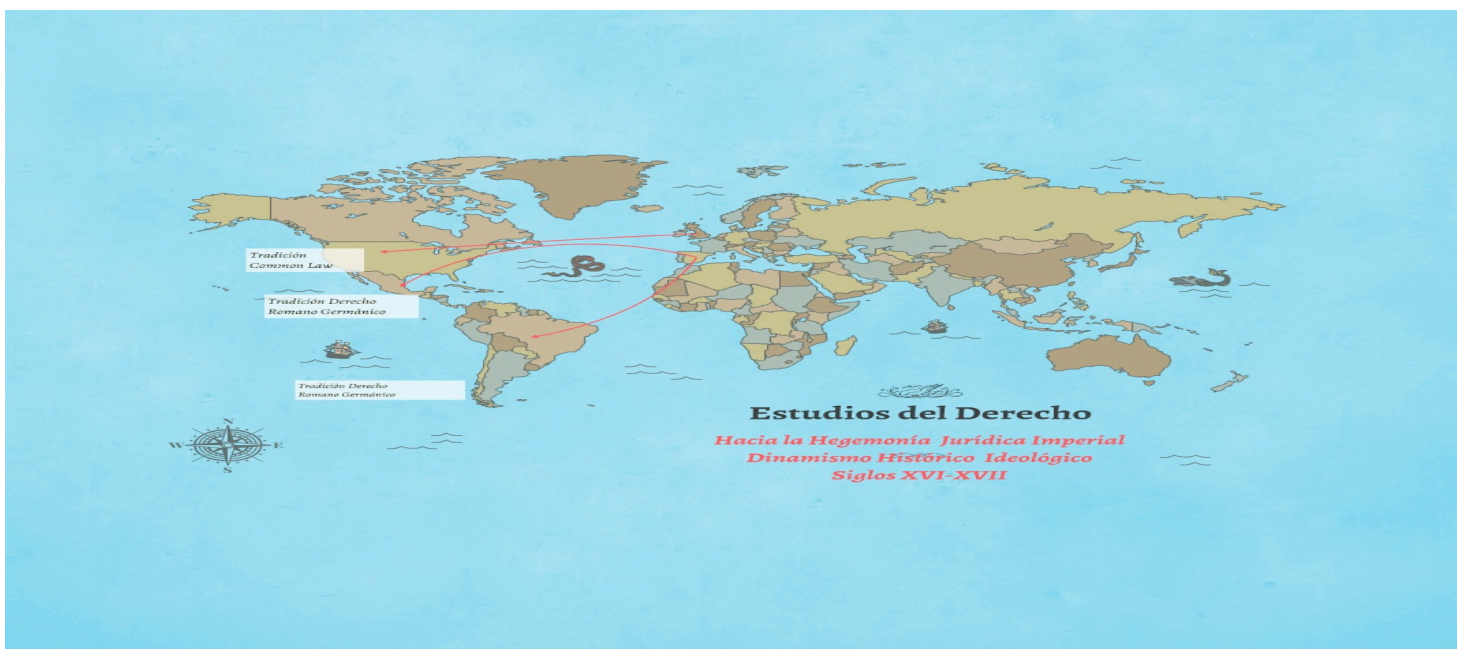

Fuente: Elaboración propia

Los primeros juristas imperiales que llegaron al Continente, ya en el sistema jurídico mundial, fueron traídos de España. Consciente el imperio mercantil de la importancia de las universidades para la hegemonía cultural y jurídica, desde el inicio en el siglo XVI, acometen su creación (v.gr. Santo Domingo, México, Lima) y la de colegios mayores (v.gr. Santa Fe, Bogotá, 1651). La enseñanza del derecho es parte esencial de estas instituciones. El paradigma fue el importado de las universidades imperiales (v.gr. Salamanca, Alcalá de Henares, etc.): el derecho romano germánico y canónico, ya que el Papa era la legitimación última del derecho de Conquista. Se enseña el derecho en la tradición escolástica aristotélica teocrática. Verdades reveladas que se asumen dogmáticamente y que la razón glosa y deductivamente concretiza y aplica a la casuística. La imprenta aún no había permitido la generalización de textos. Los alumnos copiaban en cuadernos (mamotretos) las clases de los profesores. Los alumnos memorizaban las enseñanzas y lo profesores las repetían de un año a otro (Leguizamón 2005: 139-140).

La enseñanza del derecho en los colegios mayores de nuestra América, entre los siglos XVI-XVIII, comenzaba una vez que el estudiante había aprobado materias de gramática latina, retórica, filosofía y matemáticas. Graduado como bachiller, iniciaba la formación propiamente jurídica con una duración de seis años. En este periodo tenía un núcleo obligatorio. Siguiendo el trabajo de William Leguizamón, más allá de las sucesivas reformas, se mantuvo constante: $1^{\circ}$ ) derecho romano o justiniano, en leyes (digesto y códigos); $2^{\circ}$ ) derecho canónico pontificio. Cánones (decreto y decretales); $3^{\circ}$ ) Las interpretaciones de escuela, en teología (con los libros del maestro de las sentencias) (Leguizamón 2005: 140). Aprobada la formación, recibía el título de bachiller en derecho. Podía 
continuar la formación académica hacia la licenciatura y el doctorado en derecho. Si optaba por el ejercicio, el título de bachiller en derecho le permitía trabajar como abogado en las instituciones imperiales (Leguizamón 2005: 145).. A modo de ejemplo, en las universidades y colegios mayores de Santa Fe de Bogotá los estudiantes, tanto si querían graduarse en leyes o cánones, tenían las siguientes materias obligatorias: tres de derecho romano del corpus iuris civilis (las institutas, vísperas de leyes (códigos) y prima de leyes (digesto o pandectas)) y tres asignaturas para el derecho canónico: los tres grandes textos canónicos, del decreto y las decretales) (Leguizamón 2005: 146).

Durante todo este periodo, la enseñanza del derecho colonial imperial (castellano) en las aulas de los colegios mayores y universidades evidenció una fuerte enajenación, alienación o divorcio con la realidad. Lo que se enseñaba allá muchas veces estaba alejado del derecho que se estaba produciendo en la práctica: el derecho indiano (este se iría consolidando desde 1580, apoyado en las capitulaciones), y al que no respondían los mamotretos (Leguizamón 2005: 141). Los abogados forman parte de una élite social, enajenada de la realidad y al servicio al inicio de las instituciones de coloniales del imperio, y, luego, de las instituciones de las repúblicas en el siglo XIX.

\footnotetext{
"Asimismo, la exclusión y el racismo caracterizaron la educación superior, ésta estaba reservada exclusivamente para las familias de origen español. 'Para los limpios de sangre', condición que solo permitía el acceso a una elite privilegiada con recursos económicos. Se prohibió el estudio del derecho a las mujeres, a los ciegos, sordos, pródigos o enjuiciados por adulterio, también a los condenados o juzgados por traición, por homicidio u otro delito de igual gravedad, así como a los lidiadores de bestias bravas por un precio" (Leguizamón 2005: 145).
}

$22 \S$ Llegados a esta altura en la historia, hay que seguir la remontada a no ser que se mantenga eurocentricamente que la historia en América Latina comienza con la llegada de los españoles en el siglo XV. ¿Había derecho antes? ¿Qué paradigmas tenían? Los pueblos originarios prehispánicos (v.gr. chibchas, mayas, aztecas, incas, otavalos, karankis. etc.;) tenían, y, algunos que viven siguen teniendo, su sistema de derecho, fundamentalmente consuetudinario, descentralizado, etc. (Leguizamón 2005: 137). Solo en el caso de Colombia, el Instituto Colombiano de Antropología ha identificado ocho sistemas jurídicos, entre doce grupos lingüísticos de unos ochenta pueblos (Leguizamón 2005: 138). Pero estas tradiciones jurídicas fueron sometidas; cuando posible, eliminadas e invisibilizadas por el poder colonial imperial. Aún hoy los textos de las facultades de derecho latinoamericanas comienzan la historia jurídica en Grecia y Roma. Sus ojos siguen fijos en el fetiche eurocéntrico. Están ciegos, por ejemplo, para reconocer el alcance de Caral (Perú). Hoy por hoy, también con su derecho, la 
ciudad estado más antigua del continente americano (Shady Solís y Leyva, 2003).

\section{Los estudios de derecho en Europa occidental}

23§ El sistema jurídico europeo, con sus estudios de derecho, afecta directamente a las relaciones de poder de 739 millones de europeos, con datos de 2016. Pero, no solo a ellos, en este caso. Europa está conformada por aproximadamente 50 estados. Su delimitación territorial varía según el concepto más o menos geográfico que se tome. Se suele incluir a algunos estados como Rusia y Turquía, que geográficamente son parte de Asia y Europa. Entre los países más poblados cabe mencionar: Rusia (143 mill.), Alemania (80,5 mill.), Turquía (79,7 mill.), Reino Unido (65, 1 mill.), Francia (64,6 mill.) Italia (59,1 mill.), España (46 mill.), Ucrania (44,6 mill.), Polonia (38,5 mill.). Como hemos señalado, dos grandes tradiciones jurídicas, hoy hegemónicas a nivel mundial, regulan las vidas de estos pueblos y los estudios de derecho: la tradición del derecho romano germánico y bizantino y la tradición del common law.

A modo ilustrativo, vamos a escoger tres países europeos para evidenciar las tendencias de los estudios de derecho en la Europa del siglo XXI. Elegimos, en primer lugar, dos de ellos como la cuna de las respectivas tradiciones jurídicas que van posteriormente a confluir en la creación del fetiche jurídico del capital: Francia y Reino Unido. En segundo lugar, también exploraremos qué está ocurriendo en Rusia. En este caso, por la importancia que tiene este país para evidenciar cómo el dinamismo expansivo del imperialismo jurídico del capital no solo no ha retrocedido sino que está tomando dimensiones propias de la gran bestia apocalíptica.

En el caso de Francia, existen actualmente unos 119 établissements publics à caracter scientifique, culture et professionnel (EPSCP). Estas instituciones cuentan con financiación estatal. Dentro de ellas existen 75 universidades. A su vez, dentro de estas son las unidades de formación e investigación las que otorgan los títulos o grados académicos de licenciatura, maestría y doctorado. El marco general de la estructuración de los estudios en derecho en Francia se encuentra regulado, como en gran parte de Europa, por el Plan de Bolonia (Turull i Rubinat y Rovira, 2014: 168). Para el ejercicio de la abogacía, además de la licencia se requiere un máster. Luego la preparación durante un año en algún Instituto de Estudios Judiciales, dependientes de las universidades, para superar el examen de admisión en un centro regional de formación para abogados (CRFPA). En este centro se formará en la práctica a los candidatos a abogados durante 18 meses. Finalmente han de superar otro 
examen que le permita la obtención del certificado de aptitud para la formación de abogado (CAPA) (Turull i Rubinat y Rovira, 2014: 182).

Siguiendo la investigación de Carmen Salcedo, de la Universidad de Valencia, tomamos como muestra la Universidad de Paris $X$ (Nanterre) y la Universidad de Paris I (La Sorbonne). La estructura de los estudios de derecho en Francia se articula en: licenciatura (3 años; 180 créditos), maestría (2 años más; 120 créditos) y doctorado (tres años más). En el tercer año de licenciatura, los estudios se orientan en generales y profesionales. Estos últimos, en clara respuesta a las exigencias del mercado. El contenido de los mismos se enfoca fundamentalmente en: derecho y gestión de empresas, estudios notariales, derecho y seguridad de las nuevas tecnologías, mercados y compras públicas, derecho inmobiliario, derecho de transporte, logística jurídica de la empresa, etc.

En la Universidad Paris X, la licenciatura en derecho con mención en ciencia política contempla en su contenido materias como: instituciones políticas, historia de las instituciones europeas, vocabulario jurídico, ciencias económicas, teoría general del derecho, derecho de familia, penal, constitucional, civil, internacional, derecho del trabajo, derecho administrativo, finanzas públicas, derecho empresarial, derecho comercial, derecho procesal, introducción a la ciencia política. Hay otras especialidades o menciones como en derecho público, derecho alemán, derecho español, derecho italiano, derecho ruso, en derecho administrativo. En la Universidad Paris I hay también como mención de los estudios: licenciatura en derecho e historia del arte y arqueología, derecho y economía, o derecho y ciencias de la gestión (García, 2008: 68-121; Max Turull i Rubinat y Rovira, 174-177).

En relación al Reino Unido, con respecto a la tradición del common law en los estudios de derecho (también en Irlanda), cada universidad tiene su programa y contenidos (Turull i Rubinat y Rovira, 2014: 243; 251). Buscando algunos elementos comunes de los estudios, seguimos el trabajo del profesor de Guillermo Palao Moreno, profesor de la Universidad de Valencia, en su investigación sobre los estudios de derecho en la London School of Economics, la Universidad de Oxford y la Universidad de Warwick.

Tres características dibujan el horizonte general en que se mueven los estudios de derecho en Inglaterra: competitividad, el sistema de acceso es particularmente restrictivo y competitivo, practicidad o destrezas técnico jurídicas (formación de profesionales como solicitors y barristers) y flexibilidad (García, 2008: 186); todo al servicio de la jerarquización social impuesta por el fetiche jurídico del capital. El grado en derecho (licenciatura) dura tres años (Escocia e Irlanda han establecido cuatro años). Desde 1999 se establecieron los contenidos mínimos de la licenciatura en derecho (módulos fundamentales) en Inglaterra y País de Gales García, 2008: 186). Estos módulos son: 1) derecho 
público (de este campo forma parte el derecho constitucional, el derecho administrativo y derechos humanos); 2) derecho de la Unión Europea; 3) derecho penal; 4) derecho de obligaciones (de este campo forma parte el estudio de los contratos, y la responsabilidad civil); 5) derecho de propiedad; 6) equidad (equity); y 7) derecho corporativo García, 2008: 192). Después de los dos primeros años, la flexibilidad permite la elección a los estudiantes entre un variado número de materias optativas. La ventaja de esta flexibilidad es que abre el abanico para recoger las inquietudes de los alumnos así como posibles líneas de investigación en las maestrías y doctorados, pero siempre dentro de los límites que marca la ideología del capital. La investigación en la licenciatura es cada vez mayor, y va unida a la exigencia y evaluación de los docentes entre cada cinco/siete años (Research Assesment Excercise). Los campos y problemas de investigación de estos estudios están relacionados en su mayor parte con las materias disciplinares (Turull i Rubinat y Rovira, 2014: 246-247). El modelo metodológico y pedagógico inglés en buena parte ha sido asumido por el Plan de Bolonia.

A modo de ejemplo, indicamos algunas de las materias optativas ofertadas en dos de las universidades objeto de investigación. A) Universidad de Oxford: arrendamientos mercantiles; derecho de sociedades; derecho comparado: contratos; derecho de autor, patentes y derechos conexos; derecho de autor: marcas y derechos conexos; justicia penal y penología, derecho de la competencia comunitaria; derecho del medio ambiente; ética; derecho europeo de los derechos humanos; derecho de familia; historia del derecho inglés; comercio internacional; derecho del trabajo; propiedad personal; principios del derecho mercantil; derecho internacional público; derecho romano (responsabilidad civil); derecho tributario (García, 2008: 194).

B) En la London School of Economics: derecho de propiedad (II), derecho de prueba, derecho internacional público, derecho internacional privado, derecho e instituciones de la Unión Europea, derecho del trabajo, contratos mercantiles, derecho médico, derecho de daños avanzado, derecho de asociaciones mercantiles, protección internacional de derechos humanos, derecho material de la Unión Europea, cambio legal y social desde 1750, derecho administrativo, derecho de las libertades civiles en Inglaterra y País de Gales, derecho fiscal, derecho y medio ambiente, derecho de insolvencia, antropología política y legal, legislación, derecho de los bienes inmateriales, introducción al derecho civil, derecho de las tecnologías de la información, derecho de la seguridad social I y II, criminóloga (García, 2008: 194).

En relación a las opciones de dobles titulaciones, los estudios en derecho se articulan por ejemplo con la licenciatura en español, ruso, alemán, etc. Respecto a las demás disciplinas que no son la lengua extranjera, cabe doble 
titulación: derecho y negocios, derecho y justicia criminal (Universidad de Coventry); derecho y antropología (London School of Economics), derecho y estudios legales europeos, derecho inglés y derecho americano (Kings College London); derecho y economía, derecho y política (Queen Mary); derecho y sociología (Universidad de Warwick) (García, 2008: 201-202).

En general, los estudios de derecho europeos de nuestros días se pueden caracterizar por estar orientados a mantener y expandir el imperialismo capitalista a lo largo y ancho del planeta. Sirven a la legitimación de un sistema de instituciones y relaciones de poder políticos y jurídicos con un discurso pretendidamente atemporal, ahistórico, teóricamente tecnicista y desconectado de las urgencias de emancipación de la realidad social. Considerando las tendencias generales, sin desconocer las resistencias, no tienen interés alguno en el desarrollo de destrezas profesionales críticas liberadoras, de actitudes de compromiso político emancipador (García, 2008 : 19-20). El sistema de integración académica universitaria del Plan de Bolonia, también en el ámbito jurídico, no está orientado a superar los problemas jurídicos de los pueblos europeos, sino fundamentalmente a poner la movilidad de una oferta de estudiantes y profesores al servicio de las demandas globales y trasnacionales del mercado imperial del capital. No pretende, "una integración de sistemas, estructuras o contenidos"; y menos, al servicio de la liberación del fetichismo jurídico del capital (García, 2008 : 19-20).

\begin{abstract}
"El modelo de nuestras Facultades de derecho aún proviene de un modelo de jurista que de forma acrítica se ha anclado en el tiempo no solo en la enseñanza y el aprendizaje del derecho. Los rasgos de este modelo de jurista son el énfasis en el saber enciclopédico de los contenidos curriculares unido a su estanqueidad y falta de interdisciplinariedad, los métodos docentes centrados en la transmisión de conocimientos a través de la clase magistral y la memorización como objetivo del aprendizaje y de la evaluación. Esta última verifica el que se alcancen unos resultados y no el que se hayan producido nuevos aprendizajes" (García, 2008: 119-120).
\end{abstract}

24§. A diferencia de los otros paradigmas jurídicos del resto de los continentes, el horizonte jurídico europeo, con sus dos tradiciones de derecho romano germánico civilista y common law, es hoy el paradigma imperial del capital, hegemónico a nivel mundial, como hemos indicado arriba. Hegemónico en el diseño, regulación y funcionamiento de las relaciones sociales de poder en el ámbito global, también en los estudios de derecho. Llegados a este punto no podemos dejar de preguntarnos: ¿por qué y cómo esa hegemonía?, ¿desde cuándo?

El paradigma jurídico romano germánico, que se va consolidando en Europa desde el siglo XIII, es una de las tradiciones utilizadas por el capitalismo en su colonialismo, mercantilista, industrial y progresivamente imperialista con 
ambiciones globales. Desde el siglo XV colonizó, y lo sigue haciendo, América Latina (dando lugar al inicio de sistema mundo jurídico). En el continente americano, los pueblos originarios del norte y del sur fueron engullidos de forma inmisericorde por el fetiche del derecho burgués, sea en la tradición del common law, con la colonización británica e irlandesa, como del derecho romano germánico, con la invasión española. En el África subsahariana y Madagascar, entre otros imperialismos coloniales, el imperialismo francés e inglés impuso el derecho romano germánico y common law, desconociendo la riqueza del derecho tribal tradicional consuetudinario africano; y obturó cualquier evolución de la tradición jurídica africana (v.gr. Burundi, Ruanda, Somalia, Zaire, Islas Mauricio, Seychelles, Botsuana, Lesoto, Rodesia Suazilandia). Este corsé jurídico también lo intentó imponer en el norte del continente, en disputa con el paradigma jurídico musulmán. El imperialismo jurídico del capitalismo no solo colonizó África, sino el Cercano Oriente, Japón e Indonesia.). Para su hegemonía recurrió desde el siglo XIX al fetichismo de la codificación jurídica y el legicentrismo. En China, si el imperialismo jurídico occidental no había tenido mucho impacto hasta el siglo XIX, desde la segunda mitad del siglo XX, su fetiche jurídico cada vez le resulta más útil al capitalismo de estado (David y JauffretSpinosi, 2010: 25).

25§ Ahora bien, en este punto es importante preguntarse más en profundidad por cuándo y cómo se produjo el cambio que se originó en el paradigma jurídico europeo desde el siglo XVIII para explicar su remarcada funcionalidad hegemónica mundial. En búsqueda de respuesta encontramos que precisamente a partir del siglo XVIII, los intereses de la nueva clase burguesa europea, en los albores de su capitalismo industrial internacional, necesitaban algo más que el derecho privado de la lex mercatoria para sus intercambios y empresas. Necesitan desarrollar el "derecho público de su estado burgués". En una institución europea de origen medieval, las universidades, van a encontrar el "fabricante" del instrumento. El código civil napoleónico es el punto de inflexión. A las universidades y a sus juristas se les encargará la tarea de desarrollar el derecho penal, administrativo y constitucional (burgués) durante los siglos XIX y XX. Las universidades responden con el mejor servicio inimaginable. Levantan un tremendo Moloch: la codificación legicéntrica; al que empoderan con una nueva teología: el positivismo jurídico. La adoración mundial al fetiche del derecho burgués, con su dominio opresor, había comenzado (David y Jauffret-Spinosi, 2010: 25). Codificación y positivismo jurídico se convirtieron en el mecanismo jurídico perfecto que necesitaba el colonialismo capitalista para su expansión imperial (David, Jauffret-Spinosi, 2010: 25). Los templos universitarios de derecho y el nuevo sacerdocio de juristas ya no se ocuparían 
de la justicia sino de la positivación de la voluntad del soberano; no tendrían otra función que el regreso a la glosa del nuevo derecho imperial.

\section{Dinamismo histórico hegemónico de los estudios de derechos. XIX}

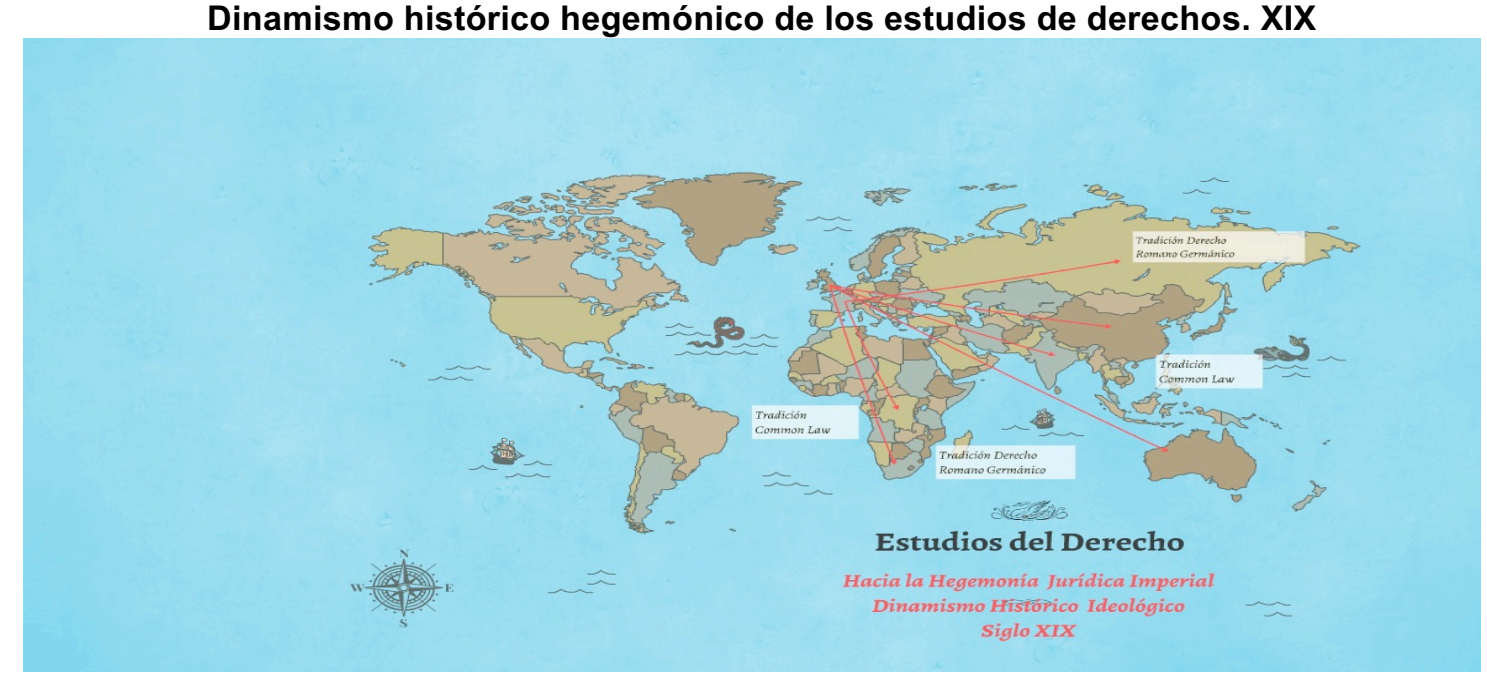

Fuente: Elaboración propia

$26 \S$ ¿Y cómo fue posible el engendro y levantamiento de tal clase de monstruo pseudojurídicoen el siglo XIX? ¿Qué había ocurrido antes, cuáles son los presupuestos históricos que posibilitaron a Saturno? Pues bien, remontándonos algo más atrás en la Historia, es necesario indagar sobre ¿cuándo aparecen esos templos de formación jurídica que son las universidades, qué contenido jurídico enseñaban, qué papel tuvieron en la formación del paradigma jurídico romano germánico que luego acomodará el positivismo jurídico en el siglo XIX? En el camino inquisitivo encontramos que el paradigma jurídico romano germánico se conforma desde el siglo XIII. Entre los siglos XI y XII, personas como Irnerio, Graciano, Odofredus, Ubaldo, Pepone, Rústicus, Bartolo de Sassoferrato, con el resto de glosadores y posglosadores, van a contribuir al "renacimiento" del derecho romano (Leguizamón 2005: 142). El crecimiento del comercio y de algunas ciudades europeas, con el dinamismo propio de la vida urbana, entre otros factores, van a suponer una exigencia al campo jurídico. Las nacientes universidades (Bolonia, 1088; Oxford, al menos desde 1096; París, 1150; Salamanca, 1218, etc.) serán parte de la respuesta. Desempeñarán un papel persuasivo fundamental (algo que no se produce en el modo cristiano ortodoxo, donde la fundación de las universidades es muy posterior, ni en África o Asia, donde el desarrollo de las universidades se produce en el siglo XIX). La universidad, como la nueva institucionalidad aparecida, inicia la progresiva expropiación de la formación jurídica popular extrauniversitaria. Los estudios de derecho en las universidades toman como misión resucitar el 
paradigma jurídico imperial del derecho romano. Según algunos autores, la prohibición a los clérigos, por el Concilio de Letrán (1215), de participar en todo juicio que implicase ordalías y juicios de Dios, significó en Europa la progresiva acogida de un derecho procesal, de inspiración canónica, más racional y también escrito comenzado (David y, Jauffret-Spinosi, 2010: 35-36). Desde el siglo XIII al siglo XVIII, las universidades se convierten en la fuente de indagación y recuperación jurídica romana, de la reflexión, comentarios y doctrina del nuevo ius commune. Los siglos XII y XIII son el auge de una escuela de derecho natural enfocada en la sistematización axiomática, lógica y deductiva de las normas de la tradición romana. Sin embargo, aunque los templos ya estaban listos, el paso hacia la hegemonía del fetichismo jurídico legicéntrico y codificador aún no se producirá. Tendrá lugar más tarde, a partir del siglo XVIII. El derecho consuetudinario seguirá siendo por un tiempo la práctica más generalizado (David y Jauffret-Spinosi, 2010: 35-36).

La enseñanza del derecho romano germánico en esta etapa histórica se orientó más hacia la reflexión teórico axiológica y el comentario glosador que hacia la aplicación procesal práctica. Las universidades, en búsqueda de su propio prestigio e impacto - así como de las exigencias de la internacionalización del comercio-, optaron cada vez más por el universalismo de sus enseñanzas. Marginaron la costumbre local de los pueblos como fuente del derecho, frecuentemente asociada a retraso e incivilización. El derecho consuetudinario resistió por doquier los ataques universalizantes abstractos; no desapareció ciertamente, pero la reflexión universitaria del nuevo derecho lo iría arrinconando y circunscribiendo fundamentalmente al ámbito familiar, sucesorio y agrario. A pesar de todo, en las universidades, obligadas en parte por el hecho de su todavía influencia, se intentaron compilaciones de derecho consuetudinario, que terminaron teniendo carácter fragmentario (David, JauffretSpinosi, 2010: 35-36). Desde la universidad se mostraba el prejuicio hacia las colecciones consuetudinarias, a las que se las calificaba como incompletas y atrasadas. Por otro lado, en lugar de desarrollar las propias tradiciones jurídicas consuetudinarias, el trabajo de su actualización consistía con frecuencia en completar las costumbres, adaptarlas y subsumirlas con el derecho romano. De esta manera quedó obturada la riqueza que podría haberse explorado por el camino de beber en el propio pozo de la tradición local y nacional. El caso de las Siete Partidas es un buen ejemplo. Queriendo retomar la tradición del Fuero Juzgo, Alfonzo X El Sabio contribuyó a la romanización jurídica española y portuguesa en el siglo XIV (David, Jauffret-Spinosi, 2010: 35-36).

"Las costumbres locales diferentes de un poblado a otro, estaban condenadas a desaparecer. Resultaba demasiado complejo conocerlas o acreditarlas; adicionalmente eran sólo aceptables en una economía cerrada y sólo podrían subsistir 
de haberlas podido agrupar y adscribirles un área geográfica de aplicación más extensa y, si una compilación hubiera permitido conocer con mayor facilidad las reglas que se desprendian de dichas costumbres... en la práctica a las costumbres locales se les reemplazó por el derecho erudito de las universidades. Los progresos del derecho romano sólo se verían limitados cuando se enfrentaron a los grandes coutumiers como las que emergieron en el siglo XIII, en Francia con la obra de Beaumanoir o en Alemania con el Espejo de Sajonia. Se les podrá limitar con la elaboración de compilaciones legislativas nuevas, como en España en el siglo XIII, con las Siete Partidas de Alfonso X EI Sabio, o mediante la redacción de costumbres, que ordena en Francia a mediados del siglo XV la Ordenanza de Montillez-Tours (1454)" (David, Jauffret-Spinosi, 2010: 35-36).

En esta etapa, el contenido de los estudios de derecho en los nuevos templos del saber fue fundamentalmente las compilaciones de Justiniano. El latín, la lengua común para su (David, Jauffret-Spinosi, 2010: 28). Excepciones fueron la universidad de Upsala y la Sorbona, que crearon respectivamente, ya en 1620, cátedras de derecho sueco y francés (David, Jauffret-Spinosi, 2010: 28). Aparte de estas excepciones, la enseñanza y actividad del derecho se centró en un primer momento en la búsqueda y explicación del sentido de las instituciones, leyes y resoluciones romanas. El mejor ejemplo de ello es la Gran Glosa de Accurse (s. XIII).

\begin{abstract}
"En las universidades, el derecho se concebía como un modelo de organización social. Su centro de gravedad no eran los juicios ni la ejecución de las sentencias: procedimiento, medios de prueba y medidas de apremio son soslayados y abandonados a la reglamentación administrativa y al estilo de los practicantes. El derecho, vinculado con la filosofía, la teología y la religión, indicaba a los jueces cómo, según la "prudencia", debían resolverse las controversias. El derecho prescribía las reglas que los justos tenían que observar en su comportamiento social. Al igual que la moral, al derecho se le conceptuaba como un Sollen (lo que hay que hacer) y no como un Sein (lo que se hace en la práctica)" (David y Jauffret-Spinosi, 2010: 28).
\end{abstract}

Progresivamente, las exigencias del dinamismo comercial, crecientemente urbano e internacional, hizo evolucionar la preocupación de los glosadores hacia un acomodo y desarrollo del derecho romano con objeto de dar respuesta a las nuevas relaciones, particularmente mercantiles y privadas, que comenzaban. El Usus Modernus Pandectarum es un ejemplo de este derecho romano actualizado desde los siglos XIV y XV (David y Jauffret-Spinosi, 2010: 28). Las exigencias mercantiles hicieron desarrollar primero el "derecho privado", en la ideológica división de la tradición romana. El desarrollo del "derecho público" tendría que esperar algo más. En estos siglos, los estudios de derecho universitarios comienzan a extender su influencia social y política. Los administradores de justicia son alumnos que se han formado en los templos universitarios. El paradigma en que han estudiado es el iusnaturalista de tradición romana. Los conceptos y categorías de ese horizonte paradigmático se 
fueron difundiendo más allá de las universidades (v.gr. derecho público, derecho privado, usufructo, servidumbre, dolo, prescripción, mandato, arrendamiento de obra, etc. (David y Jauffret-Spinosi, 2010: 28). Para la expansión del derecho romano en Italia y Alemania se recurrió a los administradores itinerantes. Estos no conocían las costumbres, y debían resolver según las orientaciones que recibían de las consultas hechas a las universidades y el communis opinio docturum (David y Jauffret-Spinosi, 2010: 28).

A pesar de todo este empuje del nuevo paradigma, la buscada expansión universalista del derecho romano tuvo sus obstáculos. Además de la costumbre local (v.gr. el norte de Francia), el derecho nacional resistía al derecho imperial. En Francia, el derecho romano fue acogido en tanto expresaba el imperio de la razón (razón escrita), pero se le resiste si es que pretende ser la razón del imperio (imperio rationis y no ratione imperii). Como razón escrita es recibido también en Castilla y León. La expansión del derecho romano no pudo ser hegemónica en los países escandinavos. Para el siglo XIV estos habían codificado su derecho consuetudinario, ahora ya como derecho nacional ( $\mathrm{v} . \mathrm{gr}$. Noruega, 1683; Dinamarca, 1687; Suecia y Finlandia, 1734) (David y JauffretSpinosi, 2010: 28). El derecho nacional será objeto generalizado de estudio en el siglo XVIII. También en el siglo XVIII se intentó en Alemania desromanizar el derecho apelando a la propia tradición nacional. Sin embargo, en el caso germano ya fue tarde (David y Jauffret-Spinosi, 2010: 28). En el sur de Europa, en Portugal, hubo similares intentos del poder político por caminar los estudios de derecho hacia un derecho nacional. El marqués de Pombal permitió resolver a los jueces en función de los intereses nacionales, y les liberó de hacerlo según la tradición de los posglosadores y doctores. Sin embargo, más allá de estas resistencias, el derecho romano era ya el derecho alemán, así como también era el derecho español, italiano y portugués (David y Jauffret-Spinosi, 2010: 28).

27§. Una vez que hemos llegado, en retrospectiva histórica, hasta el siglo XIII explorando la evolución del paradigma romano germánico, para entender el origen de los estudios de derecho actuales en Europa (y el mundo), debe hacerse lo propio con la tradición del common law.

En términos generales, los estudios de derecho en Inglaterra tienen una peculiaridad respecto a los estudios de derecho en la tradición continental europea. Se inscriben en la continuidad de una tradición jurídica consuetudinaria no interrumpida ni por la hegemonía del derecho romano germánico ni por la codificación (David y Jauffret-Spinosi, 2010: 211). Ahora bien, hoy día, el dinamismo del imperialismo capitalista, así como la lucha por la materialización y empoderamiento de los derechos, ha exigido a Inglaterra una mayor sistematización y flexibilidad a su tradicional formalismo procedimental del common law. Esto ha significado algunas reformas jurídicas en el siglo XIX. Por 
un lado, la progresiva complejidad y sofisticación que exige el dominio del imperialismo del capital ha llevado al Reino Unido durante el siglo XIX y XX a acoger una progresiva actividad legicéntrica. La acogida del fetichismo legal nacional y europeo, aunque genera algo de ruido con la tradición del common law inglés, es reclamado y funcional por la complejidad de la globalización imperial del capitalismo. Un proceso de acercamiento mutuo se ha iniciado entre el paradigma del common law y el derecho romano germánico en la Unión Europea. Ambas tradiciones están siendo exportadas y exigidas, por ejemplo, como marcos normativos en las incorporaciones de las exrepúblicas soviéticas a los organismos internacionales (v.gr. Unión Europea, Consejo de Europa, etc.). Por otro lado, las luchas, revueltas y reclamos populares contra el sofocante servilismo del casuismo jurisprudencial llevaron al common law en el siglo XX a tener que soportar una creciente actividad legislativa nacional y de tratados internacionales ( $v$.gr. tratados de derechos humanos) (David y Jauffret-Spinosi, 2010: 211).

28§ Pero ¿cuál ha sido el origen y la evolución del paradigma del common law y su modo en la formación jurídica antes del siglo XIX? Pues bien, esa tradición jurídica se inicia y desarrolla a partir del siglo XI, durante la dinastía de los Tudores (1066-1485). La conquista normanda mantuvo el derecho anglosajón -que no hay que equiparar al common law-. Guillermo el Conquistador utilizó el derecho anglosajón para legitimar el nuevo derecho feudal. Las costumbres locales se articularon (sin desaparecer) en torno a un derecho que se quiere común a toda Inglaterra: el common law. Su elaboración estará a cargo de las Cortes Reales de Justicia (Cortes de Westminster) desde el siglo XIII (David y Jauffret-Spinosi, 2010: 211)

Una de las características del nuevo common law, a diferencia del paradigma romano germánico, es la "fijación" (fetichizaciòn) en el procedimiento más que en el contenido material de la justicia.

\begin{abstract}
"Remedies precede rights: el procedimiento en primer término. El sistema de derecho del common law ha consistido desde sus orígenes en un determinado número de procedimientos (forms of action) a través de los cuales se puede pronunciar una resolución. El planteamiento crucial consistía en que las Cortes reales admitieran su competencia la demanda y, una vez admitida, de llegar hasta su conclusión a través de un procedimiento lleno de un gran formalismo. ¿Cuál sería después de agotar el procedimiento el sentido de la sentencia? No se podría atribuir a esta interrogante ninguna respuesta cierta: el common law no ha determinado más que muy lentamente las reglas que definen los derechos y las obligaciones de cada una de las partes" (David y Jauffret-Spinosi, 2010: 217.
\end{abstract}

El contenido jurídico del paradigma del common law se generó en el marco del desarrollo de un conjunto de reglas de procedimiento. Su génesis no estuvo tanto en el reconocimiento de derecho, sino en el de buscar la seguridad 
de la respuesta de la autoridad. El derecho se formaliza procedimentalmente. Por ejemplo, en el caso de los contratos, los jueces resolverán a favor o en contra si existe algún documento escrito que acredite la reclamación, más allá de si la realidad se corresponde o no con el documento (la obligación o deuda existe si existe el documento escrito). Todo ese formalismo de las acciones, aunque abolido últimamente, pervive en el arquetipo jurídico del pueblo inglés. La expansión de los procedimientos ante las Cortes reales significó un desarrollo del derecho procesal como derecho público. La separación entre derecho público y derecho privado (de origen romano) fue negada desde la práctica. Todo el derecho comenzó a entenderse como derecho público (David y Jauffret-Spinosi, 2010: 219-220 ). La formación de los administradores de justicia se enfocó prioritariamente hacia el formalismo del procedimiento:

\begin{abstract}
"Los procedimientos arcaicos, típicamente ingleses, obligaron caso por caso a "naturalizar" las ideas que podían tomarse, en cuanto al fondo, al derecho romano o al derecho canónico. Era tal la complejidad y la técnica de estos procedimientos que sólo a través de la práctica se podían conocer. Una formación universitaria, fundada en el derecho romano, podía contribuir a visualizar la resolución justa que implicaba una controversia; más no permitía ganar un proceso. Juristas y jueces, en Inglaterra, se forman incluso hasta nuestros días esencialmente en la práctica, a diferencia de los países del continente europeo; una formación universitaria no resultaba necesaria, y es en forma excepcional que un abogado o un jurista hubiera, hasta el siglo XX, recibido esta formación" (David y Jauffret-Spinosi, 2010: 221).
\end{abstract}

Sin embargo, el sacrificio de la justicia en el altar de procedimentalismo generó reacciones. Un ejemplo es la reivindicación y desarrollo de las reglas de equity (1485-1832). El mecanicismo rutinario procedimental del common law, su formalismo, y la dificultad de, con ese horizonte, responder y anticipar respuestas en justicia a la realidad jurídica, todo ello, generó la revuelta de la equity. Este modo de hacer justicia se extendió desde el siglo XVI, como recurso ante el monarca de obtener allá la justicia que las cortes le habían denegado. La motivación de la justicia no era ya el formalismo del procedimiento, sino la apelación a la conciencia y caridad del monarca. El nuevo reclamo se fue extendiendo, creando jurisprudencia y aplicándose cada vez más por un jurista en lugar de por el canciller o confesor real. El paradigma de la equity resolvía, inspirado, en buena medida, en el derecho canónico y el derecho romano germánico (David y Jauffret-Spinosi, 2010: 222). Esta rebelión estuvo cerca de conseguir hacer que el paradigma del common law fuese sustituido por el de derecho romano en Inglaterra. Sin embargo, el frescor de la rebelión fue pronto absorbido y esclerotizado en el formalismo procesalista del common law. "Las reglas referentes a los remedies de la equity entretanto se tornaron, al paso de los siglos, tan estrictas y tan "jurídicas", como las del common law; su vinculación 
con la "equidad" resultaba similar al que conservaban las propias reglas del del common law." (David y Jauffret-Spinosi, 2010: 224).

Un factor que contribuirá a la hegemonía del common law es que este paradigma respondió rápido a las exigencias del naciente capitalismo mercantil e industrial. El common law integra pronto en su seno el derecho mercantil con el derecho civil (considerado hasta entonces como derecho internacional) (David y Jauffret-Spinosi, 2010: 224). Para los estudios de derecho, los repertorios de las decisiones judiciales se convierten en los manuales fundamentales para el sacerdocio de glosadores jurídicos que necesitaba el nuevo proyecto industrial y colonial del capitalismo inglés (v.gr. los Comentarios de Blackstone, 1765-1769).

29§ Ahora bien, ni el derecho ni sus estudios comienzan en Europa con la tradición romano germánica y el common law. ¿Qué paradigma jurídico y de estudios de derecho había antes del siglo XIII en Europa? En este nuevo paso de remontada histórica constatamos que desde el siglo XII d.C hasta el siglo VI d.C, los pueblos germánicos y eslavos se dieron sus propias codificaciones legales, estas tenían un ámbito territorial local, en la mayor parte de los casos limitadas en su influencia, fuese por el desconocimiento, el lenguaje esotérico o por la prevalencia de la costumbre jurídica como fuente principal del derecho (era todavía común en el siglo XVI escuchar en el norte de Europa el siguiente dicho referente al trabajo de jurista, como actividad de una élite, del sacerdocio de la ley: Juristen, böse christen (los juristas son malos cristianos) (David y JauffretSpinosi, 2010: 26). El arbitraje, la conciliación, la caridad y en su caso la intervención de la autoridad del jefe eran los medios del derecho consuetudinario. Los ostrogodos y visigodos intentaron alguna codificación con pretensiones de generalización en Italia (la Lex Romana Wisigothorum o Brevario de Alarico, 506 y el Edicto de Teodorico, 500) y en España (Fuero Juzgo 654/694). El intento quedó truncado en Italia por las invasiones lombardas en 565 y en España por la invasión árabe de 711) (David y Jauffret-Spinosi, 2010: 26).

Hacia el siglo VI d.C., el contenido del derecho romano, con mediación escrita, que se enseñaba y aplicaba era fundamentalmente las compilaciones de Justiniano del Código, Digesto e Institutas (David y Jauffret-Spinosi, 2010: 26). Sin embargo, esta formación va a encontrar sus dificultades. Las resistencias al imperio desde el norte de Europa y sus oleadas de invasiones, mal llamadas "bárbaras", desintegraron al imperio romano en Occidente en el siglo V. d.C. La relación derecho consuetudinario-sumisión al derecho imperial se dinamitó. La pluralidad de los derechos personales de las diferentes oleadas de los pueblos del norte (tribus) vino a sustituir al derecho imperial. La progresiva unificación de estos pueblos en el nuevo territorio conquistado haría pasar del derecho personal 
a un nuevo horizonte jurídico territorial: el derecho feudal (David y JauffretSpinosi, 2010: 26).

Dando un paso más atrás, entre el siglo I a.C y el siglo V.C en la Europa occidental se impone la relación derecho consuetudinario local propio-sumisión al derecho imperial romano. Las invasiones del imperio romano mantuvieron sus costumbres jurídicas, a salvo de las disposiciones de imposición romana. Dados los límites de la extensión del trabajo, nos quedamos tocando la puerta de esta época así como la del paradigma jurídico europeo antes del imperialismo romano. Solo indicamos que, compartiendo rasgo común con los otros continentes, el paradigma jurídico hegemónico, también en la enseñanza, fue el consuetudinario y descentralizado.

En el caso del Reino Unido, en la excursión histórica continuando con la indagación: ¿qué paradigma de derecho y modo de estudios había antes de la llegada normanda a la isla? Pues bien, antes de la conquista de los pueblos normandos (1066) el derecho consuetudinario de los diversos pueblos que poblaron Inglaterra, Gales y Escocia fue el derecho hegemónico. Un horizonte influido por el cristianismo desde el siglo $\mathrm{V}$ con su derecho canónico, particularmente desde la conversión de estos pueblos al cristianismo en 596. Los pueblos germánicos Sajones, Jutes, Anglos, Daneses, extenderán por la isla su influencia con su derecho. Se da inicio al llamado derecho anglosajón. De este periodo se conoce algunos tímidos intentos de codificaciones jurídicas en forma de leyes, pero en el lenguaje propio anglosajón y no en latín. Preludiando el paso al feudalismo son Las leyes del rey danés Canute (1017-1035). Un dinamismo del que hay intentos mucho antes, por ejemplo, las leyes de Aethelbert, rey de Kent (600), cuyo contenido no iba más allá de 90 frases cortas. Pero como en los casos de otros pueblos europeos, el ámbito de las leyes escritas era limitado en su contenido y alcance territorial (el derecho era local, descentralizado, no había un derecho común a todo el territorio). La hegemonía del derecho consuetudinario no estaba puesta en peligro (David y Jauffret-Spinosi, 2010: 212).

Entre los siglos I a.C y V d.C., al igual que en la Europa continental, la relación derecho consuetudinario-sumisión al derecho imperial fue hegemónica; sumisión circunscrita principalmente al reconocimiento de emperador y al pago de tributos, permitiéndose el derecho local consuetudinario propio en los otros ámbitos. Esta hegemonía del derecho consuetudinario se retrotrae antes de la llegada de los romanos en el siglo I (emperador Claudio), campo de exploración que dejamos aquí para ser continuado.

\section{Los estudios de derecho en Rusia}


$30 \S$ El sistema jurídico ruso, con sus estudios de derecho, afecta directamente a las relaciones de empoderamiento de 143,4 millones de rusos, con datos de 2016. Pero no solo, sino que lo hace en uno de los países más diversos étnicamente del mundo. Su sistema educativo forma a unas 176 etnias diferentes, con porcentajes aproximados: rusos $(79,8 \%)$, tártaros $(3,8 \%)$, ucranianos $(2 \%)$, bashkires $(1,2 \%)$, chuvashios $(1,1 \%)$, bielorruso $(0,8 \%)$ y otros $(11,3 \%)$.

Actualmente Rusia tiene 1.129 instituciones universitarias con estudios jurídicos (547 públicas y las demás privadas). De ellas, en 208 se oferta doctorado (142 públicas y el resto privadas) Turull i Rubinat y Rovira, 2014: 258). La genuflexión al fetiche jurídico del capital en Rusia a partir de 1989 ha supuesto, como reconoce Valentina Smorgunova, un impacto muy significativo en los estudios de derecho y un aumento de las instituciones dedicadas al estudio del derecho. El número se ha multiplicado por más de cincuenta en las últimas dos décadas. Pero la formación jurídica en Rusia se hace también fuera de la Universidad, en el ámbito de la formación profesional no universitaria (entre los 16 a 18 años, dos años de duración) con el objetivo de que estos jóvenes puedan asesorar a las pequeñas empresas en materia de contratos, relaciones laborales y contabilidad. Entre las materias que se imparten son sistema jurídico ruso, derecho civil, derecho mercantil, derecho penal, derecho administrativo (Turull i Rubinat y Rovira, 2014: 257).

En 1995 el Ministerio de Educación aprueba el contenido nacional de los estudios de derecho. Normativa que se ajustará posteriormente a los requerimientos del Plan de Bolonia. Rusia hoy se ha adherido al modelo de Bolonia. Ha organizado los estudios en licenciatura (cuatro años) y el doctorado. Los campos en torno a los que giran los estudios del derecho son: derecho civil, penal, comercial y administrativo. Cinco son los ámbitos en los que los estudiantes pueden elegir materias optativas para ir dirigiendo su especialización: derecho penal, justicia criminal, derecho civil, derecho internacional, derecho constitucional y teoría del derecho, entre otros (Smorgunova, s.f: $1-5 ; 1$ ).

El plan de estudios estatal establece unas materias básicas: $1^{\circ}$ Semestre: lógica, teoría del derecho y estado, derecho constitucional; $2^{\circ}$ Semestre: derecho romano, historia del derecho y del estado de Rusia y otros países; derecho constitucional; teoría del derecho y el estado; $3^{\circ}$ Semestre: derecho administrativo, derecho civil, derecho penal, derecho procesal civil, derecho procesal penal, derecho procesal administrativo; $4^{\circ}$ Semestre: derecho administrativo, derecho civil, derecho penal, derecho procesal civil, derecho procesal penal, derecho procesal administrativo; $5^{\circ}$ Semestre: derecho procesal administrativo, derecho procesal civil, derecho procesal penal, proceso de 
arbitraje, derecho laboral; $6^{a}$ Semestre: proceo de arbitraje, derecho laboral, criminalística; $7^{\circ}$ Semestre: derecho humanitario internacional, derecho financiero, derecho fiscal, derecho ecológico; $8^{\circ}$ Semestre: derecho internacional, criminología, medicina forense (Turull i Rubinat y Rovira, 2014: 260).

A estas materias, las diferentes universidades pueden añadir otras obligatorias. Siguiendo el trabajo de Elena Startseva y Oksana Zhevnyak, a modo de ejemplo, en la Universidad de Moscú se exige: historia de Rusia, contabilidad jurídica, derecho familiar; derecho municipal; derecho comercial; derecho mercantil internacional; control fiscal; derecho penitenciario, y derecho constitucional internacional. Aparte de estas, los alumnos pueden elegir 6 entre 47 ofertadas: problemas de derecho procesal civil; derecho civil internacional; derecho corporativo; contratos en diferentes esferas; derecho laboral internacional; derecho de propiedad intelectual; regulación legal de la publicidad; características de los diferentes casos en los juzgados; regulación legal del mercado de valores; derecho de correduría; derecho energético, etc. (Turull i Rubinat y Rovira , 2014: 261).

Con especial urgencia, en los primeros años después de la caída socialista de 1989, se crearon comisiones parlamentarias y presidenciales para el diseño de la nueva arquitectura jurídica. El modelo era el sistema jurídico del capitalismo occidental. El "exitoso" triunfador de la guerra fría. En muchos casos, dada la urgencia de Saturno, del Moloch jurídico occidental, el diseño de los estudios de derecho requeridos no venía de las universidades (que tienen un ritmo más lento para responder a la demanda) sino de agencias de expertos extranjeros, corporaciones y firmas jurídicas mundiales.

Dentro del campo civil, comercial y administrativo, los estudios de derecho en Rusia más urgentes para las necesidades del capital, entonces y ahora, se pueden clasificar según los siguientes ámbitos en: $1^{\circ}$ ) derecho civil y mercantil general: derechos de propiedad, derecho de corporaciones mercantiles, instrumentos de negociación, tipos de contratos, derecho concursal, competición, comercio internacional, derecho del trabajo, protección de los consumidores, protección del medioambiente, fiscalidad; $2^{\circ}$ ) derecho civil y mercantil específico: finanzas y créditos (inversiones, seguros bancarios, bolsa de valores, banca central, fondos de inversiones, etc.), privatización de las empresas estatales; $3^{\circ}$ ) adecuación del derecho administrativo a la nueva arquitectura jurídica; $4^{\circ}$ ) derecho comparado: estudios eclécticos tomando fundamentalmente como guía modelos extranjeros; 5) "urgencia" desde 1990 por la recodificación civil y mercantil capitalista (una fiebre compartida también por los países del Centro y Este de Europa, v.gr. Albania, Bulgaria, Polonia, República Checa, Rumanía, etc.) (Ajani, 1995: 104; 106; 108-109). Dos siglos más tarde se repite la obsesión 
codificadora. Entonces fue de la burguesía europea occidental, que a través de la codificación civilista, siguiendo a Gian Maria Ajani, estableció dogmas como: a) la capacidad legal general de los individuos y entidades legales; b) la eliminación de las limitaciones al comercio "libre" de bienes, a la venta de la tierra y a la propiedad dentro del Estado; c) el mayor ámbito de autonomía para las relaciones contractuales (Ajani, 1995: 107-108;110).

El doblegamiento del socialismo ruso en 1989 ha significado para los estudios de derecho la aparente clausura de la ya pequeña posibilidad de crear un derecho fuera de la hégira del capitalismo. Por el contrario, está significando, además del abandono del neotradicionalismo jurídico, la invasión a gran escala (también en el centro y oeste de Europa) del colonialismo jurídico occidental, de naturaleza romano germánico civilista y common law. Muchas instituciones capitalistas occidentales (v.gr. USAID, OCDE, OMC, BM, FMI, UE, German Technical Cooperation Governmental Office (GTZ), French Interministerial Mission for Central and Eastern Europe (MICECO), Dutch Government's Center for the Cooperation with Eastern Europe; Council of Europe, EFTA, UNCITRAL, European Bank for Reconstruction and Development, Centros de Universidades Occidentales, etc.) han fundado grupos de "expertos legales" para "ayudar" a diseñar la nueva estructura jurídica del país ( $v$.gr. la ley de compañías joint-stock, de 1995 (Ajani, 1995: 93; 110-111; Granik, 1993: 237). Pero no solo se dedican a proponer proyectos legales, hacen también estudios sociojurídicos sobre la eficiencia y eficacia de las normativas, así como diseñan propuestas para direccionar la formación y estudios que las facultades de derecho de las universidades rusas deben impartir para que puedan asumir la complejidad del derecho capitalista. El sistema jurídico ruso socialista no era apropiado para el capitalismo. Su transformación pronto ha sido urgida por las empresas, corporaciones e instituciones internacionales que desean "seguridad jurídica" para la propiedad de sus negocios ( $v$.gr. leyes rusas sobre la banca a demanda de las instituciones financieras internacionales). El imperialismo jurídico del capital ha entrado en Rusia con la pretensión de hacerse hegemónico en cualquiera de sus dos tradiciones internas o con ambas a la vez.

Se ha vuelto una prioridad reconstruir el sistema legal ruso y sus estudios de derecho a la imagen y semejanza del sistema jurídico occidental del capital para facilitar la armonización, estandarización legal y "racionalización jurídica" que exigen los mercaderes extranjeros y nacionales. Ciertamente la realidad rusa de este último cuarto de siglo evidencia la urgencia del mercado del capital internacional de "seguridad jurídica" para su ciclo de expropiación originaria, producción y apropiación del capital en su realización en la fase de circulación. Desde Marx y Engels, Weber, pasando por North, hasta los teóricos de la globalización concuerdan en la eficiencia del derecho al servicio del mercado. 
Sin embargo, también es evidente la dificultad que encuentra la vorágine imperialista en el voluntarismo del positivismo jurídico, asimilado durante el periodo soviético. Se le hace difícil al pueblo creer la prédica del derecho como un instrumento "imparcial" y "neutral" garantizador del complimiento de las inversiones ( Hendley,1997: 228; 235).

La realidad del día a día en los estudios de derecho es cuestionante. En 1999, cuatro alumnos de derecho del sistema ruso hicieron una investigación sobre los problemas de los estudios y la enseñanza del derecho en Rusia. El equipo estuvo conformado por: Tatiana Levina, estudiante del cuarto año en derecho, de la Universidad Estatal de Ciencias Humanitarias, Maria Lizorkina, estudiante de segundo año de la Universidad Estatal de Moscú, Maria Philippova, estudiante graduada del Departamento de derecho del Intituto Estatal de Moscú en Relaciones Internacionales, y Dennis Rybakov, graduado en el Departamento de derecho de la Universidad Estatal Educacional. El estudio lo realizaron en el marco del proyecto de investigación Pericles American Business \& Legal Education Project, Moscow, y fue presentado en el Seminario American Assistance to Legal Reform in Russia, organizado por la Yale University Law School, en abril de ese mismo año ${ }^{7}$. El trabajo tiene especial relevancia para nuestra investigación porque identifica, desde el punto de vista de los alumnos, los principales problemas en la eseñanza de los estudios de derecho en Rusia. Destacamos a continuación los principales:

$1^{\circ}$ Falta de cultura de respecto y confianza en el derecho en Rusia, que se refleja en las aulas. El mundo de lo que se dice y enseña en las aulas dista mucho de la práctica del abogado, que ejerce entre la corrupción de las instituciones, muchas veces la propia, y la burocrática.

$2^{\circ}$ El proceso de acceso a las facultades de derecho es altamente corrupto. Aunque desde 2013 existe regulación nacional sobre el acceso, el problema que detectaron los estudiantes investigadores aún no se ha resuelto del todo. En el momento de su investigación evidenciaban la arbitrariedad de un sistema de acceso donde el contenido de los exámenes de ingreso no estaba estandarizado, ni había seguridad sobre qué era finalmente lo que se les iba a preguntar. Ello forzaba a los alumnos a buscar en la universidad a la que se postulaba profesores privados para ser preparados (con un alto coste económico). Pero ni incluso así aseguraban el éxito en el examen si es que este profesor no estaba en el tribunal examinador.

$3^{\circ}$ La degradante atmósfera de desmoralización de los estudiantes en las aulas. La corrupción en el proceso de acceso continúa a la hora de aprobar las materias. No es el esfuerzo y el trabajo lo que asegura el buen desempeño

\footnotetext{
7 Pericles, American Business \& Legal Education Project, Problems of Legal Education in Russia. http://www.pericles.ru/able/articles/legal/03_problems.html.
} 
académico sino el engaño en los exámenes y el pago de coimas. Es el mejor modo de adiestrar al abogado en hábitos para el ejercicio posterior.

$4^{\circ}$ Deficiente cualificación académica y de habilidades profesionales, fuente de la mala reputación social de los juristas en Rusia.

$5^{\circ}$ Desprestigio de las facultades de derecho de las universidades más alejadas de los grandes centros políticos del país. Ello dificulta, por ejemplo, a los buenos estudiantes que viven lejos de Moscú o San Petersburgo, el desarrollo profesional con posibilidades de acceso laboral.

$6^{\circ}$ La deficiente información y coordinación nacional de la oferta de estudios de derecho y especializaciones en las diferentes universidades, para que los alumnos puedan escoger en función de sus inquietudes y posibilidades.

$7^{\circ}$ Becas muy reducidas, que en ese entonces no eran más de 600 rublos (24 dólares mensuales).

$8^{\circ}$ La necesidad de trabajar de la mayoría de los estudiantes para poder responder a los gastos de vivienda, alimento, libros, etc.

$9^{\circ}$ Desintegración de los sílabos de derecho. Se presentan las materias sin conexión coherentes unas con otras. Desintegración también reflejan en el contenido de las materias, que no comienzan con una introducción y contextualización interdisciplinar. Más parece una acumulación caótica de "libros sagrados" donde nadie explica por qué y cómo son los que son y de esa manera.

$10^{\circ}$ Ausencia de apertura interdisciplinar en el diseño curricular que posibilite la entrada a materias que evidencien que el derecho es una relación social conectado con otras relaciones sociales que necesitan conocerse (v.gr. filosofía, humanidades, etc).

$11^{\circ}$ Teorización de los estudios de derecho, con relegación del aprendizaje desde la práctica. Solo al final del tercer año tienen los alumnos un mes de pasantía, y tres meses en el quinto año.

$12^{\circ}$ Subjetividad y arbitrariedad de los profesores en el modo fundamentalmente oral de realizar los exámenes a los alumnos. Estos suelen durar unos 15 minutos. Los alumnos disponen de 30 a 40 minutos previamente para preparar el examen (que suelen utilizar para clandestinamente buscar la información de cualquir modo).

$13^{\circ}$ Bajos salarios de los profesores de derecho. Los buenos profesores se marchan de las universidades. Los profesores con frecuencia tienen que buscar dos, tres o más trabajos. No les queda tiempo para su preparación académica ni la preparación de las clases. El salario de estos muchas veces no les alcanza para comprar la normativa actualizada, menos para la bibliografía científica en la materia. No todas las universidades tienen acceso a bases de datos jurídicas (Turull i Rubinat y Rovira, 2014: 261-2). 
$14^{\circ}$ La pedagogía en las clases es la lección magistral, la mayor parte de las veces es la repetición de la lección de un manual, trabajo que el alumno puede hacer solo. No se crea atmósfera de discusión académica crítica en las aulas, en parte por la falta de conocimiento de los profesores.

$15^{\circ}$ La edad media de los profesores es elevada, dado que los jóvenes buscan mejores salarios en otras actividades. El cambio social dramático vivido en Russia en las últimas décadas hace que muchos de estos profesores dediquen gran parte del tiempo a exponer en clases su opiniones políticas.

$31 \S$ Ahora bien, no es suficiente con este paisaje para entender el dinamismo histórico, hace falta continuar inquiriendo: ¿por qué ha llegado la situación de colonialismo jurídico en Rusia al grado actual? ¿Cómo eran los estudios de derecho antes de 1989? Pues bien, cuando triunfa la Revolución Bolchevique, en 1917, había en Rusia 65 Escuelas Superiores y 50 Escuelas Superiores no estatales. En 1919, la mayoría de las facultades de derecho fueron cerradas y no serán reabiertas hasta la década de los cincuenta. Poco antes del colapso de la URSS, en 1986 el país contaba con unas 65 universidades, de las cuales en 45 había facultades de derecho, aparte de 4 institutos. El número de graduados en derecho en Rusia era por entonces aproximadamente el 15\% de todos los graduados en humanidades. Estos, en proporción, diez veces menos que en Francia y cinco veces de los graduados en Estados Unidos (Smorgunova, s.f : 1). Durante la revolución bolchevique (1917-1989), el sistema jurídico ruso, en términos generales, asumió un paradigma positivista instrumental del derecho. El derecho era un mero instrumento (parte de la ideología) de dominación de clases. Sería necesario en la transición socialista hacia la sociedad comunista. Una vez llegados a esa etapa, con la superación de las contradicciones de clase, y la eliminación de la sociedad capitalista, el derecho desaparecería subsumido en un mayor grado de moralidad del pueblo. Más allá de algunas disputas e intentos los estudios de derecho soviético no se construyeron desde los presupuestos del materialismo histórico. El dogmatismo de algunos postulados del materialismo histórico y dialéctico impidió abrir la fecundidad de un nuevo horizonte jurídico.

$32 \S$ La formación jurídica, con sus estudios, sin embargo, no empieza en Rusia con la revolución bolchevique. ¿Qué paradigma y formación jurídicos había antes? ¿Qué papel desempeñaron las universidades y facultades de derecho? Pues bien, en una primera constatación hay que decir que a diferencia de la Europa Occidental, los templos jurídicos universitarios, el sacerdocio de sus juristas y la influencia de la codificación legicéntrica tardaron en aparecer en Rusia.

"Hasta épocas recientes, no hubo juristas en Rusia: la primera universidad rusa, la de Moscú, se creó hasta 1755; la universidad de San Petersburgo se 
creó hasta 1802; y no fue sino hasta la segunda mitad del siglo XIX cuando emergió una literatura jurídica rusa y una reforma judicial de 1864 para que se organizara el primer colegio de abogados y que la carrera de magistrado y la carrera administrativa pudieran estar sometidas a regímenes diferentes. Existía una gran confusión entre las funciones de policía, de administración de justicia y de la administración pública. El derecho escrito ruso era, por otra parte, totalmente ajeno a la conciencia popular. El derecho era esencialmente un derecho administrativo; la parte de derecho privado que contenía un "derecho de las ciudades" para uso exclusivo de los comerciantes y de la burguesía. La gran masa campesina lo ignoraba y aún actualmente sigue rigiendo su conducta conforme a sus costumbres; los campesinos únicamente reconocen un solo régimen de propiedad familiar (dvor) o comunal (mir) al margen del régimen de propiedad individual regulada por la ley; para los campesinos la justicia estaba y está representada por la equidad, tal y como era administrada por el tribunal del volost, compuesto de juzgadores elegidos que no eran juristas; el tribunal del volost dependía del Ministerio del Interior y no del Ministerio de Justicia. El derecho de los juristas [...] se constituía por disposiciones legislativas, que provenían del criterio arbitrario de un soberano autócrata o de privilegios de la burguesía. El mismo soberano se encontraba por encima de la ley; la ley se identificaba como su voluntad: princeps legibus solutus. Los juristas eran servidores del tsar y del Estado, más que del derecho; no existía entre ellos una convicción de cuerpo colegiado" (David y Jauffret-Spinosi, 2010: 124).

Desde finales del siglo XV hasta el siglo XVII, cuando se hace con el trono Pedro el Grande (1689), el paradigma hegemónico es el feudalismo jurídico, vasallaje impuesto por los zares. En este periodo se intentó la codificación de los Libros de Justicia (Sudebnik, de 1497 y de 1550) y las compilaciones, actualizaciones Kormtchaia, parte de la tradición codificada en el Ruskaia Pravda y el derecho bizantino. Algunos códigos tuvieron su relativa influencia en esta época como el Código de Alejo Mijáilovich, 1649 (David y Jauffret-Spinosi, 2010: 123). Desde el siglo XVII (1689) hasta el siglo XX (1917), más allá de algunas regulaciones jurídicas en la organización administrativa del estado, la costumbre siguió siendo dominante en Rusia. En 1687, en Moscú, se crea la primera institución especializada en los estudios de derecho: la Academia HelenoGriega. Aparte de dedicarse a estudiar los fundamentos de la Iglesia, su tarea se centraba en los estudios de derecho civil. Los profesores eran traídos de la Universidad de Padua. En 1725 se crea el primer germen universitario con tres "facultades", una de ellas de derecho. Ahora bien, conviene no magnificar el impacto. El número de estudiantes de toda la universidad eran ocho al inicio, y de procedencia alemana. Durante las siguientes décadas la media de estudiantes era de treinta. En 1755 se funda la universidad de Moscú, acogiendo 
una facultad de derecho. Se materializaba con ello una idea de Mikhael Lomonosov. Durante los primeros 20 años se enviaban alumnos a la universidad de Glasgow para profundizar estudios. Por otro lado, desde 1775 la Academia Heleno-Griega cambia el nombre a Academia Eslavo-Griego-Latina y se centra en los estudios rusos de derecho. Con todo, los estudios seguirán siendo caracterizados por la generalidad y la perspectiva filosófica. Con esta orientación entrarán en la nueva centuria (Smorgunova, s.f: 1.)

A comienzo del siglo XIX los estudios de derecho reciben un gran impulso. La codificación francesa seduce en un inicio a las autoridades rusas. El estado burgués necesitaba el aparataje jurídico. Sin embargo, el conflicto con Napoleón I condujo a tomar la opción de consolidar la codificación del derecho tradicional ruso antes que acoger el modelo positivo francés. Como resultado, al final del primer cuarto de siglo, el imperio de Nicolás (1825-1855) dio un giro para distanciar a Rusia de las ideas liberales occidentales. Se prohibió enviar alumnos a las universidades occidentales, estudiar sus leyes y traer a sus profesores. Por el contrario se procuró conocer y aplicar el derecho ruso, fundamentalmente La Colección Completa de Leyes Rusas (publicado en 1833) y el Código de Leyes del Imperio Ruso (publicado en 1833, 15 volúmenes). La codificación Svod Zakonov (1832), ecléctica y casuística, tenía un fuerte contenido de derecho público (dos terceras partes (David y Jauffret-Spinosi, 2010: 123). En 1855 se codifica un código penal —en 1861 se elimina el vasallaje-. La codificación de derecho civil no acabó de publicarse. Sobre el contenido de los estudios de derecho, el $70 \%$ del contenido de las materias eran disciplinares propias de los departamentos con orientación muy instrumental y utilitarista. En la segunda mitad del siglo XIX el dinamismo del capitalismo va a ir mostrando algunas de las limitaciones de las opciones por el derecho propio del cuarto de siglo anterior. Se inicia entonces un proceso de nueva recepción del derecho capitalista occidental, ahora más moderno. A partir de 1864, con la reforma judicial, aparece la profesión independiente de los abogados. Esto hizo aumentar el número de los abogados, aunque seguían siendo un número reducido. A finales del siglo XIX y principios del XX representaban aproximadamente el $40 \%$ del total de los estudiantes universitarios rusos, su número ascendía a 850 (Smorgunova, s.f.:1). La enseñanza del derecho tenía como metodología la clase magistral y el método deductivo. En definitiva, más allá de estas influencias, algunos autores mantienen que en términos generales, la tradición del paradigma jurídico ruso no ha sido el romano germánico sino el romano bizantino, dada la influencia de la Iglesia.

“...la ciencia del derecho en Rusia tomó como modelos el derecho bizantino —es decir en el derecho romano- y de los Estados de Europa continental pertenecientes al sistema romanista. Existen sin discusión costumbres y ordenamientos rusos pero, al 
igual que en Francia y Alemania en el siglo XVII, en Rusia no hay otra ciencia del derecho que la ciencia de los romanistas. Las categorías del derecho ruso son en consecuencia fundamentalmente las mismas del derecho romanista. La concepción del derecho que se desarrolla en las universidades y en los juristas rusos es la concepción romanista. El hecho que el derecho ruso se encontrase contenido en una compilación de orden casuística, no precluye que el jurista ruso haya concebido al derecho con una naturaleza jurisprudencial; al igual que sus homólogos alemanes o franceses, el jurista ruso concibió a la regla de derecho, como una regla de conducta prescrita a los individuos y cuya formulación incumbe a la doctrina o el legislador, y no al juez. Si Rusia no contaba en su acervo legislativo con códigos a semejanza de otros países de Europa continental, estaba presta para tener códigos" (David y JauffretSpinosi, 2010: 123).

$33 \S$ Pero no nos podemos quedar aquí, porque la explicación aún no es completa en el tiempo: ¿qué paradigma jurídico, también de los estudios de derecho, había en Rusia antes del feudalismo bizantino? Pues bien, parece que el derecho consuetudinario fue en Rusia, como hemos visto en otras regiones, el horizonte jurídico desde los inicios. Pueblos escandinavos, los varegos, llegaron en 862 y se establecieron en Rusia hasta que en 1236 fueron desplazados por los mongoles. La conversión al cristianismo de Vladimiro (989) acelera el proceso formular por escrito, en eslavo, el derecho consuetudinario. La mediación escrita era un instrumento útil para la predicación del cristianismo. Ya para el siglo XI, Kiev cuenta con compilaciones consuetudinarias. Es un derecho territorial, anticipo de un sistema feudal. Entre los siglos XIII y XV, el dominio de los pueblos mongoles (1236-1480) dejó su huella en un derecho consuetudinario mongol llamado yazak (David y Jauffret-Spinosi, 2010: 123). Sin embargo, la mediación escrita tenía un alcance limitado. La práctica local del derecho consuetudinario mantenía una hegemonía que provenía desde mucho antes en la historia de los pueblos que habitaron las tierras de Rusia.

\section{Los estudios de derecho en Estados Unidos}

$34 \S$ El sistema jurídico estadounidense, con sus estudios de derecho, afecta directamente a las relaciones de empoderamiento de 324.000 .000 de habitantes, con datos de 2016. Pero su impacto no se circunscribe solo al territorio de EE.UU. Como ocurre con el common law del Reino Unido y el derecho romano germánico continental europeo, la expansión de esta tradición jurídica es alcance global, mundial, imperial.

En Estados Unidos se forman aproximadamente unos 45.000 abogados al año, para unos 25.000 puestos disponibles. El sistema de estudios en derecho comienza, previa una formación universitaria, con un grado de tres años (90 créditos; unas 11 horas y media por crédito). Se obtiene el grado de Doctor en Jurisprudencia. Luego le sigue la maestría (un año y título LLM) y el doctorado. 
Cada universidad establece su sistema de autorregulación, en el marco de los criterios de la Asociación Profesional de la Abogacía. Como sugiere Jaume Saura y Cesare P.R. Romano, más que de facultades de derecho sería mejor llamar escuelas de derecho a estas instituciones dado el carácter profesionalizante de las mismas y la gran discrecionalidad para la determinación de los contenidos, como para establecer los requisitos de selección. En el país hay 200 escuelas de derecho con acreditación federal, aparte de otras muchas con acreditación estatal y sin acreditación (Turull i Rubinat y Rovira, 2014: 144).

Respecto a la estructuración del currículo, las materias fundamentales del primer año son: 1) propiedad; 2) contratos; 3) derecho penal; 4) derecho procesal civil; 5) responsabilidad civil. Coincidiendo con el análisis de Duncan Kennedy, esto es la iniciación al capitalismo jurídico del laisse faire del siglo XIX (Kennedy, [1982] 2004: 127). Además de estas materias existen otras en el primer año que varía según facultades: 6) derecho constitucional; 7) derecho administrativo; 8) derecho transnacional; 9) curso de orientados a la práctica jurídica. Después del primer año, solo hay una materia obligatoria (v.gr. ética legal, evidence), las demás son optativas, para que el alumno forme su perfil (Spencer, 2012: 2021). Las materias del segundo y tercer año responden, en palabras de D. Kennedy, al "programa reformista moderado del 'New Deal' y a la estructura del Estado regulador moderno". Asignaturas como historia, filosofía o práctica jurídica quedan marginadas (Kennedy, [1982] 2004: 127; Turull i Rubinat y Rovira, 2014: 146) .

La realidad socioeconómica de los estudios muestra que se han encarecido, así como reducido los ámbitos de realización de las pasantías. Además, las grandes firmas jurídicas han concentrado el trabajo y precarizado muchos de los salarios. La mayor parte de los graduados en derecho acaban endeudados, con malos trabajos y mal preparados para el ejercicio (Spencer, 2012: 1953-4). Frente a esto, llama la atención que los profesores universitarios de derecho, según el estudio de The Chronicle of Higher Education (2010-2011), cuentan con los salarios anuales más elevados en comparación con el resto de las otras disciplinas; $59,5 \%$ más alto por ejemplo que un profesor de inglés. Como mejor pagados le siguen los profesores de negocios y administración de empresas y los profesores de economía. Los salarios oscilanban entre 90.000 y 190.000 dólares anuales, llegando en algunos casos a 300.000 (Spencer, 2012: 2048-2049).

Los estudios de derecho en Estados Unidos en la actualidad, siguiendo el trabajo de A. Benjamin Spencer, se caracterizan por la hegemonía de un paradigma doctrinal que dura más de siglo y medio: el modelo Langdell Harvardiano. El derecho como la ciencia de la objetividad de la letra escrita (fetiche) (Spencer, 2012: 1975; 2002). Desde entonces se estableció una 
formación académica de tres años en los templos universitarios de las facultades de derecho y sus sacrosantas bibliotecas (Spencer, 2012: 2001).

Ideológicamente, desde fuera del país, en muchas facultades de derecho de otras regiones se suele idealizar y poner de modelo tanto los contenidos como la pedagogía de los estudios de derecho en Estados Unidos. Para ir desmontando este mito, e ir dimensionando el alcance del problema que genera la hegemonía imperialista expansiva del fetiche jurídico del capital, conviene, siguiendo a A. Benjamin Spencer, detenernos en conocer algunas de las críticas al sistema de los estudios de derecho desde dentro del mismo:

a) Es un sistema de estudios jurídicos fundamentalmente unidimensional cognitivo; que no articula la dimensión cognitiva de los estudios con la dimensión ética (axiológica) y la dimensión práctica;

b) El currículo se encuentra desestructurado en general, sin una coherencia interna más allá de las demandas del mercado. El alumno acaba por emborracharse con una gran cantidad de reglas y definiciones pero incapaz de entender el sistema e incluso de que pueda formar el suyo propio. Está destinado a instruir más que a educar. Se ha centrado fundamentalmente en materias para el adiestramiento en la litigación, en el derecho como conflicto judicial. Hay ausencia de materias que tomen en cuenta que el derecho es además el ámbito de la negociación, de los acuerdos, de la legislación, de la regulación, así como de la interdisciplinariedad que se acerca al derecho como una relación o hecho social (Spencer, 2012: 1084; 2007; 2023-24; 2036);

c) Centrado en el aprendizaje de la doctrina legal. La docencia reproduce una pedagogía de aprendizaje de conceptos abstractos enajenados de la realidad;

d) Limitado por las carencias del método estudio del caso-diálogo. Método de aprendizaje tal vez más útil cuando el derecho anglo-americano era en su mayor parte no escritolbid.. El método del estudio del caso-diálogo ha terminado en el estudio de las opiniones jurisprudenciales para resolver el caso. Se ha olvidado, como denunciaba Jerome Frank, que el estudio del caso es también el estudio de sus circunstancias, de su contexto político, ideológico, económico, etc.; en definitiva, de la vida real del caso. Este método del aprendizaje se ha mostrado en parte ineficaz para transmitir la necesaria y sustancial información jurídica, asimismo incapaz para responder a la formación en todas las competencias profesionales que requiere el estudiante. Útil para el desarrollo de ciertos tipos de análisis legales, pero incapaz de desarrollar competencias para la resolución de problemas (problem-solving skills) concretos como los que se encuentra el abogado en su ejercicio (Spencer, 2012: 2029; 2031; 2038);

e) Se asienta sobre el punto de partida de cómo piensa el abogado y no en cómo trabaja el abogado en la práctica; 
f) Tiene cierta apertura de materias optativas para recoger los intereses de los alumnos, pero férreo clausura cuando estas materias quieren desbordar los límites de la ideología del capital;

g) Adolece de insuficiencias en la enseñanza de la práctica jurídica. En el supuesto cuestionable de que la solución sea el paternalismo de la clínica jurídica, solo una pequeña parte de las facultades exige la práctica clínica. Muchos de los estudiantes se gradúan sin tener experiencia en clínica jurídica (Spencer, 2012: 2018). La práctica clínica solo es accesible al $30 \%$ de los estudiantes de derecho en las facultades que la ofrecen. En total representa aproximadamente el 9\% de la carga horaria de toda la carrera (Spencer, 2012: 2008);

h) Las aulas de las universidades siguen siendo el templo (el hospital ficticio) donde se enseña el derecho;

i) Cuenta con profesores de gran formación académica pero relativamente poca experiencia práctica (Spencer, 2012: 2061-63; 2048);

j) Se evalúa fundamentalmente a través de un solo examen a final del semestre, que valora casi exclusivamente el aprendizaje cognitivo de las doctrinas en la resolución de un caso creado por el profesor. La calificación del examen es más en función de los mejores y peores (una media subjetiva) que en función de la adquisición de unos conocimientos, valores y habilidades o destrezas objetivos (Spencer, 2012: 2039-2047; Turull i Rubinat y Rovira, 2014: 147-149).

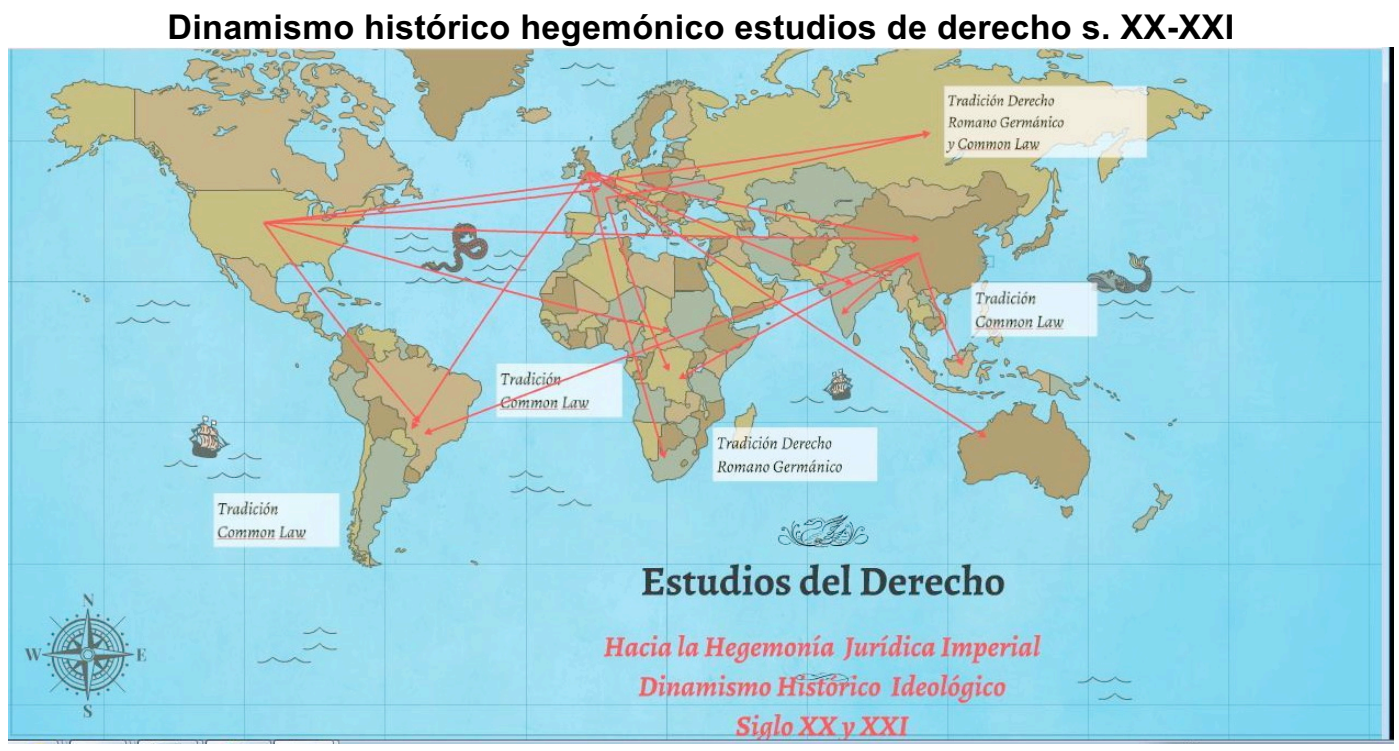

Problemata: R. Intern. Fil. v. 8. n. 1 (2017), p. 324-402 
Fuente: Elaboración propia

35§ Pero así como hemos venido preguntando en los demás casos, hay que cuestionarse: ¿por qué está así la formación jurídica en Estados Unidos?, ¿cuándo comienza a hacerse hegemónico en Estados Unidos este paradigma del common law adaptado? Explorando respuestas encontramos que la formación profesional académica de derecho en EE. UU. se inicia en 1779, por inspiración de Blackstone, a imagen de la universidad de Oxford. En este siglo se crean escuelas de derecho, aún no dentro de universidades como facultades de derecho, pero sí ya como formación académica. La mayor parte de las escuelas de derecho se crean en el siglo XIX. La escuela de derecho de la Universidad de Harvard fue fundada en 1817. Para 1870 ya se habían creado 31. En esta época, la duración de la formación era de uno o dos años. Las materias: constitutional law, American jurisprudence, English common law, equity, I, pleading, evidence, bailments, insurance, bills and notes, partnerships, domestic relations, conflict of laws, sales, and real property. Materias como la historia, la filosofía, ética, etc., fueron dejadas fuera. Quedaba a la voluntad del interesado si quería buscar la formación en donde se impartiera (Spencer, 2012: 1969). En 1870, con Chr. Langdell, como Decano de la escuela de derecho de la Universidad de Harvard, comienza un nuevo paso en el paradigma del fetichismo jurídico. Se va a ir extendiendo el método y contenido landgdellharvardiano en los estudios de derecho. La universidad rompe con la tradición de enseñar y aprender el derecho según el método de aprendizaje de pasantía, directamente con un abogado. El "hospital" de la realidad de la vida jurídica es suplantado por las bibliotecas y facultades universitarias.

Todavía hacia 1895 coexistían ambos caminos como intercambiables: el segundo, más orientado a la formación práctica; el primero a la orientación teórico-académica. Sin embargo, las demandas del imperio naciente, así como de la complejidad de la vida urbana y relaciones económicas necesitaban otro modo de preparar a los operadores jurídicos. El método de la pasantía como aprendizaje de la profesión ya no resultaba suficiente (Spencer, 2012: 1963). Hacía falta conducir a los futuros operadores jurídicos a la universidad. En la universidad se hace hegemónico el método langdell-harvardiano (Spencer, 2012: 1993). En 1906 el método del nuevo paradigma se había extendido, entre otras, en las escuelas de derecho de Chicago, Northwestern, Cincinnati, Stanford, Wisconsin, Hastings, y Tulane (Spencer, 2012: 1980). Algunos factores fundamentales lo explican: a) Los diferentes estados van a ir acogiendo el nuevo paradigma jurídico como identidad política (v.gr. Texas en 1840 y California en 1850); b) la extensión de las escuelas de formación jurídica, particularmente después de la Guerra de Secesión (1861-1865); c) un sistema de formación jurídica más sistemático, pragmático, y menos centrado en el formalismo 
procesal; d) su utilidad para las exigencias del comercio internacional y la justificación expansionista del nuevo imperio en gestación (David y JauffretSpinosi, 2010: 211).

$36 \S$ Ahora bien si, como también en otras regiones, un punto de inflexión en los estudios del derecho en Estados Unidos fue el siglo XIX, ello nos lleva a querer desentrañar otras cuestiones: ¿cuál era el paradigma y la formación jurídica en EE. U.U. antes del siglo XIX? Para intentar responder, la historia estadounidense nos indica que hay que diferenciar una primera etapa, que se remonta hasta la llegada de los peregrinos y colonizadores europeos a este territorio; y otra etapa que es el paradigma jurídico de los pueblos originarios antes de la conquista. Respecto a la primera fase, en ascensión histórica anterior al siglo XIX, hay que señalar que los primeros colonos desconocían en general el common law. En su lugar, comenzaron aplicando un derecho creado desde las necesidades locales, y orientado por los preceptos bíblicos.

\footnotetext{
“... el common law era sencillamente inaplicable en territorios donde no existía prácticamente ningún jurista, sea cual hubiera sido la variedad de su población, y donde no existía la inquietud de hacerle venir a ningún jurista o de instruir a uno; las reglas del common law, por otra parte, habían sido elaboradas por y para una sociedad feudal, respecto de la cual los primeros asentamientos humanos americanos estaban muy distantes" (David y Jauffret-Spinosi, 2010: 285).
}

Sin embargo, cuando comienzan a aumentar y complejizarse los conflictos sociales, precisamente el desconocimiento general jurídico y la ausencia de juristas en los inicios de la colonización llevará a las nuevas colonias a optar por la seguridad jurídica de la codificación legislativa, antes que por la inseguridad y formalismo jurisprudencial. Massachusetts (1634) y Pennsylvania (1682) optaron pronto por sus primeras codificaciones normativas. Las carencias de producción jurídica propia, la escasa formación de los jueces, las exigencias del comercio y la presión del colonialismo francés presente en Canadá y la Luisiana francesa llevaron a las colonias, asentadas en territorio hoy estadounidense, a acoger algunos de los instrumentos generados en la tradición del common law como el Statute of Frauds (1677). En Filadelfia se imprimirán en 1771-1772 los Comentarios sobre el common law de Blackstone (David y Jauffret-Spinosi, 2010: 286). Sin embargo, la recepción del common law inglés como derecho generado en la metrópoli tuvo su inflexión en 1776. Una vez declarada la independencia, las fuentes normativas que se siguen, aparte de aquellas, son las generadas por las nuevas colonias estadounidenses (David y Jauffret-Spinosi, 2010: 286). Respecto a la enseñanza del derecho prerrevolucionaria durante los siglos XVII y XVIII consistía en la lectura de los textos de common law inglés y la práctica como aprendiz pasante junto con un abogado (Spencer, 2012: 1962). 
$37 \S$ En la indagación sobre el derecho, y su formación, antes de la colonización europea del territorio hoy estadounidense encontramos que el derecho de los pueblos originarios de esas tierras, como del resto de pueblos del continente americano, era consuetudinario y así se enseñaba. Urge explorar esta tradición aún viva en nuestro continente.

\section{Conclusiones}

$1^{\circ}$ Los problemas en los contenidos y enseñanza de los estudios del derecho son sistémicos, propios de un sistema mundo jurídico. Después de hacer un acercamiento panorámico a la realidad mundial de los contenidos curriculares, así como de las investigaciones, metodología y pedagogía, la primera constatación que encontramos es que los ordenamientos jurídicos hegemónicos de los distintos países y regiones del mundo forman parte de un sistema mundo jurídico. Es un error acercarse a ellos pensando que existe autarquía jurídica dentro de las fronteras de los estados. Asimismo es un error analítico acercarse al estudio de alguno de ellos desconociendo el dinamismo histórico que lo interrelaciona con el sistema. Así como respecto a las economías de los países, autores como I. Wallerstein, han mostrado que no se las pueden entender sin integrarlas en dinamismo histórico de la geopolítica del sistema mundo, lo mismo ocurre con respecto a los estudios de derecho. Estos son sistémicos. No se les puede entender aisladamente sin integrarlos en el sistema mundo jurídico.

Una evidencia encontrada en la exploración es que los problemas de los estudios del derecho de cualquier continente, región o país del mundo muestran un alto grado de coincidencia y semejanzas con los del resto de regiones y rincones del planeta. Se puede afirmar que la problemática es sistémica, global. Esta segunda constatación viene a desmentir como errado un análisis que se repite con frecuencias en las aulas de las colonias jurídicas. Es habitual, por ejemplo, en las facultades de derecho del Ecuador, México y otros muchos países de nuestra América, que los docentes sostengan que el padecimiento del formalismo jurídico así como las glosas normativas de las clases magistrales se debe a un retraso, a una fijación medieval, respecto a otras tradiciones jurídicas más pragmáticas, como la del common law estadounidense, que acogió la revuelta realista y pragmática ya desde inicios del siglo XX. Se engaña a los pueblos azuzando la pelea entre dos tradiciones de un mismo paradigma. Como hemos mostrado en el trabajo, esto es falso, la tradición del common law estadounidense, como también del inglés, adolecen de problemas de fijación casuística o jurisprudencial semejantes a los de la tradición romano germánica. El origen del malestar en los estudios de derecho, en una u otra de las tradiciones, se encuentra en la esencia del mismo paradigma hoy hegemónico. Son 
problemas sistémicos consustanciales al paradigma jurídico hegemónico mundial.

Esta primera conclusión implica entonces que si se quiere pensar en abordar la solución de los problemas de los estudios de derecho debería hacerse, en primer lugar, de forma sistémica. Esto es, asumiendo, por ejemplo, que los problemas concretos de currículos, sílabos, metodologías de la investigación, pedagogías, etc., de una facultad o centro de estudios jurídicos, están relacionados unos con los de otros, así como los de un país o región con otros, y todos con el sistema mundo jurídico. En segundo lugar, la conclusión también implica que la búsqueda de solución habrá de tener alcance y horizonte sistémico mundial. Las acciones, aunque sean humildes en su pretensión e impacto, deberán estar orientadas por ese horizonte utópico de superación del sistema mundo jurídico hegemónico.

$2^{\circ}$ los problemas principales de los estudios del derecho en el sistema mundo jurídico son exigencias del fetiche jurídico del capital: a) formalismo codificador, normativista o jurisprudencial; b) dogmatismo monodisciplinar; c) colonialismo etnocéntrico; d) enclaustramiento universitario; e) metodología de la investigación monodisciplinar exegético-glosadora de textos; f) pedagogía docente de clase magistral dogmático deductiva; g) funcional al imperialismo capitalista.

El formalismo codificador, sea en la deriva normativista o jurisprudencial, es una constante, como hemos visto, en países europeos como Francia, Inglaterra o Rusia, y también lo es India, China, África. Igual sucede en el continente americano con la tradición del common law estadounidense o con el normativismo legicéntrico en América Latina. En términos generales, la mediación del texto de la norma o la jurisprudencia ha suplantado al derecho mismo como praxis jurídica.

Otra constante es que en todas las regiones es hegemónica la asunción práctica de la ciencia del derecho como "dogmática", monodisciplinar autorreferente, de un ordenamiento normativo textual. El derecho, como texto normativo, es presentado en sus articulados como versículos de un libro "legal", "sagrado"; una Biblia, Torá o Corán desconectado de la praxis política, ideológica, praxis moral, etc. La interdisciplinariedad —que no es el eclecticismo de algunos programas - en los estudios del derecho es prácticamente un ausente a nivel mundial. El contenido del derecho queda circunscrito a la exégesis de la voluntad del legislador expresada en texto normativo.

Una tercera constante encontrada en la exploración regional y continental es el evidente carácter colonial etnocéntrico de los estudios de derecho a nivel mundial. El paradigma jurídico europeo, en cualquiera de sus dos tradiciones, romano germánica o common law, es el hegemónico hoy en el ámbito mundial. 
Es sorprendente que casi 7.500 millones de personas en el planeta hayan sido sometidos a tal "adoración jurídica" y despojo e indigencia de la propias tradiciones. Vastas regiones en Asia, como India, China o continentes enteros como África o América, aparte de Europa, han sido sometidos a un modo etnocéntrico europeo de pensar, sentir y actuar las relaciones sociales de poder.

La cuarta constante generalizada muestra que la universidad, las facultades, han terminado apropiándose y monopolizando los espacios y tiempos para la "enseñanza" del derecho. En un proceso histórico, la democratización horizontal del aprendizaje y la práctica local comunitaria consuetudinaria del derecho ha ido progresivamente desvalorizándose y eliminándose. Las universidades terminaron también absorbiendo el aprendizaje extrauniversitario por pasantía (v.gr. en E.E.UU.). Las universidades, como templos del nuevos saber jurídico esotérico, han sustituido, concentrando, centralizando y hegemonizando los estudios de derecho. La mayor parte del tiempo de formación jurídica lo pasan los estudiantes entre las paredes de las aulas de la facultad. El mundo de la realidad de los derechos en acción queda reducido, en los casos en que funciona para algunos afortunados, en la excursión cuasi-simulada de unos tres o cuatro meses por las "clínicas jurídicas". El mundo de la vida diaria de los pueblos con sus conflictos y luchas, como el verdadero "hospital de la realidad jurídica", es suplantado para esconderse en atrios sagrados donde se escuchan sermones interminables. Así como parece absurdo que un médico pretenda aprender medicina con maniquís sin tocar la enfermedad y los enfermos reales, iqué absurdo parece que el estudiante de derecho huya del malestar jurídico de su comunidad o pueblo, como el mejor laboratorio para el aprendizaje e investigación jurídica, y se recluya por cuarenta horas a la semana y durante tres, cuatro, cinco años o más entre unas paredes y montañas de libros.

Otra quinta constante histórico-jurídica es la carencia de interdisciplinariedad en los estudios de derecho. La ciencia que ha secuestrado el mundo del derecho es la dogmática jurídica como ciencia del texto de los ordenamientos jurídicos. Al mundo del derecho se le ha expropiado la axiología, la moral, pero también la política, la ideología, la economía, la historia, etc. Ciertamente hay algunos intentos, como hemos visto en México, Brasil, Estados Unidos, por incorporar el conocimiento de estas otras disciplinas. Además de seguir siendo minoritarios, se suelen quedar en el ámbito del eclecticismo. Los estudios del derecho, además de tener como problema fundamental (ontológico) la ausencia de un paradigma integrado de la acción (de la praxis) que dé cuenta de la toda la riqueza del hecho del derecho, tiene un problema respecto a su método. El derecho no acaba de encontrar un método propio para la investigación. Un método que articule, sin caer en el eclecticismo, la riqueza 
interdisciplinar e intercultural de modos de acercarse, analizar sistémicamente y verificar o probar los postulados explicativos de la realidad.

La sexta constante observada en todas las regiones es la hegemonía de una pedagogía clerical a través de la que se inculca los estudios de derecho. Es una educación bancaria, diseñada para la obediencia a la jerarquía social. Las clases son dominantemente magistrales, dogmáticas, llenas de dogmas y verdades reveladas, ritualistas, incluso fetichistas en la vestimenta sagrada del terno, traje y corbata, y cabello fijado con gomina. El alumno es un sujeto pasivo en su participación, o en todo caso mero recurso para engordar el narcisismo del profesor.

La séptima constante nos muestra que el modo de estudios de derecho hegemónicos a nivel mundial, con sus características, problemas y limitaciones, es funcional al imperio del capital. Es decir, el fetiche jurídico imperialista necesita sacerdotes de la toga que no miren las vidas de los pueblos, sus dolores y sufrimientos, sino las letras de las verdades reveladas en los textos jurídicos. Necesita un ejército de expertos formados fundamentalmente en derecho mercantil, derecho de negocios, derecho civil, derecho comercial y derecho penal, servil a los intereses del capital. No cabe esperar otro tipo de estudios en este horizonte. Así como Dostoievski decía que la manera más perfecta de conocer a una sociedad es ver cómo trata a sus presos, el estado de fetichización e indigencia de los estudios de derecho a nivel mundial es el verdadero rostro del fetiche del capital.

Esta segunda conclusión tiene fundamentales consecuencias. Si los problemas universalmente compartidos que padecen los estudios del derecho son consustanciales al paradigma del fetiche jurídico del capital no se puede esperar dentro de ese horizonte un cambio, una renovación en los mismos. Se impone por tanto la superación, aunque sea desde la humildad de la luz que se enciende. Se necesita explorar, adentrarse hacia un paradigma iusmaterialista y socialista o comunista, frente al idealismo del fetiche capitalista. Lo que ha de ocupar a los estudios del derecho son las relaciones sociales de poder en su lucha (dialéctica) histórica como fuerza (derecho propiamente) vs. violencia (contraderecho). Esto es imposible hacerlo sin introducir integradamente en los sílabos y en la mallas de los planes de derecho materias como historia jurídica crítica, antropología jurídica, sociología jurídica, psicología jurídica, economía política, axiología o ética, pluralismo jurídico, sistemas de justicia originarios (v.gr. justicia indígena).

$3^{\circ} \mathrm{El}$ siglo XIX es el momento histórico de inflexión para la hegemonía colonial imperialista de sus estudios de derecho. En la historia de los estudios del derecho no todos los momentos históricos ha tendido la misma relevancia por sus consecuencias. Es en el siglo XIX cuando se desencadena la mayor 
colonización a la que ha asistido la humanidad en sus 200.000 años. Confluyeron en este tiempo el precipitado de: a) la universidad europea, como institución de educación superior creada en la Edad Media; b) la generalización del libro como medio de información, gracias al desarrollo de la imprenta moderna desde el siglo XV; c) la codificación jurídica en Francia, con el código civil napoleónico como icono de la fiebre codificadora; d) el imperialismo colonial europeo; e) la urgencia imperial de "regular" las relaciones sociales de poder de las regiones y pueblos colonizados al servicio de la acumulación de capital, de más poder y de la dominación cultural.

$4^{\circ}$ El colonialismo jurídico imperialista del capital tiene su origen histórico, hoy más reforzado que nunca, en la Europa occidental (con sus tradiciones de derecho romano germánico y common law) y en Estados Unidos. La exploración regional que hemos realizado muestra que hay un origen y dirección de fetiche jurídico del capital. El dinamismo de expansión hacia la hegemonía mundial se inicia como sistema mundo con la invasión española de América. Allá llegaron los europeos con "su derecho", universidades, libros y dogmatismo docente. Lo mismo ocurrió con la tradición anglosajona en Estados Unidos y Canadá. En el siglo XIX se produce otra segunda oleada expansiva de la colonización europea hacia África y Asia. En el siglo XX y XXI se refuerza la agresión jurídica imperial inglesa y europea continental, a la que se une EE.UU., particularmente hacia Rusia y China. Esta se está convirtiendo en un foco de reflector regional, con pretensiones globales.

La cuarta conclusión nos pone ante el recrudecimiento hoy día del dinamismo imperial jurídico europeo-estadounidense contra los pueblos. A quienes no queremos someternos al imperio nos queda resistir e ir ganando espacios para el "otro derecho". Urge por tanto decolonizar las mallas, los sílabos, el contenido de las materias, así como nuestro propio modo de conocer, sentir y practicar el derecho. Urge fortalecer los estudios (y la práctica) del derecho enlazando con la historia jurídica consuetudinaria olvidada y ninguneada de los nuestros pueblos.

$5^{\circ}$ El fetiche jurídico del capital han convertido a la ley (la norma) en la fuente primera del derecho (legicentrismo). Una deriva idealista interesada en expropiar a los pueblos la costumbre (el poder de la acción de la praxis) como fuente primera del derecho (una fuente descentralizada y popular de empoderamiento jurídico). A lo largo de la historia hemos visto cómo la dialéctica codificación-expropiación ha estado presente (con sus riesgos en interés en el fetichismo del texto y también de la costumbre), sin embargo no fue hasta el siglo XIX que se extendió esa fiebre por todos los continentes virtualizando el derecho consuetudinario vivo de los pueblos. 
Esta conclusión, para superar el fetiche del capital, nos pone un tremendo desafío. Ciertamente la costumbre por sí misma no es necesariamente buena para la vida de los pueblos y la naturaleza, ni está libre de fetichizarse. No es esto lo que queremos indicar, sino mostrar la importancia, para acabar con el fetiche, de entender el derecho como "praxis", como acción, con poder real para satisfacer bienes jurídicos para la vida de los pueblos y la naturaleza. Es mostrar la importancia de desvelar que el derecho fetichizado como norma (texto), es impotente para dar vida jurídica a los pueblos y la naturaleza, pero es tremendamente poderoso para devorar a los explotados, oprimidos y engañados. Es mostrar que su superación exige abandonar los templos universitarios e ir a la escuela del pueblo. En concreto, por ejemplo, esto significa reordenar el tiempo-espacio de los estudios del derecho. Los estudiantes podrían dedicar tres días a la semana conociendo, trabajando y comprometiéndose con el derecho en acción de las comunidades donde vivan. Esta práctica estaría iluminada con el trabajo autónomo de diversas lecturas apropiadas, e investigaciones. Dos días a la semana los alumnos se reunirían junto con el profesor en seminarios o grupos de investigación para compartir la problemática, sus análisis y la búsqueda de soluciones al derecho vivo. El trabajo de campo, no las aulas deberían ser el espacio-tiempo fundamental. El derecho es una ciencia de las relaciones (acciones) de poder de la vida, allá debe estar la investigación y el estudio. Ese es su hogar.

Pero esta última conclusión conlleva desafiantes implicaciones en el ámbito de la teoría del derecho, que dejamos apuntando. Si el contraderecho del fetiche del capital, con sus estudios, es consustancialmente una praxis ideológica violenta, con genoma imperialista y en estado de guerra permanente, tal vez el imperialismo no sea solo la fase superior del capitalismo (Lenin) sino que también sea fase originaria; que las relaciones de dominación sembradas por doquier por el contraderecho sean condiciones de surgimiento del modos de esclavitud moderna "voluntaria" como el capitalismo. Tal vez sea interesante hacer su relectura desde las relaciones sociales de poder de dominación vs. poder de vida y liberación.

Para terminar quisiera recordar una advertencia, que nos sirve frente al vaciamiento que el fetiche jurídico del capital está generando en nuestros estudios de derecho. Decía Dostoievski que la naturaleza teme al vacío, la materia tiende a llenarlo todo. Sin embargo hay una excepción: el cerebro humano. Cuanto más vacío lo dejan más difícil es llenarlo.

\section{Bibliografía}

Ajani, G. (1995). «By chance and prestige: legal transplants in Russia and Eastern Europe». The American Journal of Comparative Law: 93-117. 
An-Naim, A.A. (2007). "La Sharía en el estado secular: Una paradoja de separación y fusión». Anales de la Cátedra Francisco Suárez, vol. 41: 9-31.

Boétie, Étienne de La, [1548-1549?],1935). De la servidumbre voluntaria. Madrid: Sociedad Española de Librería.

Cheng, R. 2014. L'association des avocats de la République Populaire de Chine: une approche comparative au regard du droit français. Thèse de doctorat en droit comparé. Lyon: Université de Lyon.

Courtis, Ch. (Ed.) (2006). Observar la ley: ensayos sobre metodología de la investigación jurídica. Madrid: Trotta.

Dasgupta, L. (2009). «Reforming Indian legal education: Linking research and teaching». J. Legal Educ. 59: 432-449.

David, R, y Jauffret-Spinosi, C. (2010). Los grandes sistemas jurídicos contemporáneos. México: UNAM; Instituto de Investigaciones Jurídicas; Centro Mexicano de Derecho Uniforme; Facultad Libre de derecho de Monterrey.

García Añón, J. (2008). Los estudios de derecho en Europa Alemania, Francia, Italia, Reino Unido e Irlanda. València: Publicacions de la Universitat de València. Gordon, R.W. (1981). "Historicism in Legal Scholarship». Yale Law Journal: 1017-56

. (1984) «Critical legal histories». Stanford Law Review: 57-125.

.(1987). «Unfreezing legal reality: Critical approaches to law», Fla. St.

UL Rev. 15: 195-220.

(1988). "The Independence of Lawyers». BUL Rev. 68: 1-83.

Gupta, D. y Gupta, N.(2012). "Higher education in India: structure, statistics and challenges». Journal of education and Practice 3, n.o 2: 17-24.

Hendley, K. (1997). "Legal development in post-Soviet Russia». Post-Soviet Affairs 13, n.o 3: 228-251.

Kennedy, D. (1970). "How the law school fails: a polemic». Yale Rev. L. \& Soc. Action 1: 71-90.

(1982). "Legal education and the reproduction of hierarchy». Journal of Legal Education: 591-615. Citado según la traducción en revista: Academia 2, 3 (2004) 117-147.

.(1985). "Role of Law in Economic Thought: Essays on The Fetishism of Commodities». Am. UL Rev. 34: 939-1001.

Beard Books.

(2006). Rise and Fall of Classical Legal Thought. Washington D.C:

Lecuona, E. (2006). «Historia del derecho y ciencia jurídica en los Estados Unidos de América: el debate en torno al historicismo crítico de Robert $W$. Gordon». Revista de estudios histórico-jurídicos, n.o 28: 589-611.

Leguizamón Acosta, W. (2005). "Enseñanza del derecho y formación de abogados en la Nueva Granada 1774-1842». Historia de la Educación 
Colombiana 8: 135-154.

Lin, L. (2009). "Historia del Derecho Chino y su Sistema Jurídico Contemporáneo». En Fiz-Fierro H. y Oropeza García, A. (Coords.). El sistema juridico en la República Popular China. México DF: UNAM: Instituto de Investigaciones Jurídicas: 1-31. Citado según la numeración de páginas de:

http://biblio.juridicas.unam.mx/libros/libro.htm?l=3020

Manteaw, S. O. (2008). "Legal education in Africa: What type of lawyer does Africa need». McGeorge L. Rev. 39: 910-72.

Marx, K. ([1842] 2007). Los de bates de la Dieta Renana. Barcelona: Gedisa.

Montoya Vargas, J. (2009). "Educación jurídica en América Latina: dificultades curriculares para promover los temas de interés público y justicia social». La educación legal y la garantía de los derechos en América Latina. El Otro derecho, n.o 38 (Bogotá): 29-42.

Piquet, P. (2008). «Les réformes juridiques chinoises entre harmonie imposée et représentations». Trabajo de investigación. Montréal: Université du Québec à Montréal Faculté de Science Politique et de Droit Département des Sciences Juridiques: 1-38.

Rodrigo Martinez, S. (2011). "A evolução do ensino jurídico no Brasil». Jus Navigandi, Teresina, ano 10: 1-15.

Salamanca Serrano, A. (2008). Filosofía de la Revolución. San Luis Potosí, México: Facultad de Derecho Universidad Autónoma San Luis Potosí.

Ecuador.

. (2011). Teoría socialista del derecho, 2 vols. Quito: Editorial Jurídica del

(2015). «La investigación jurídica intercultural e interdisciplinar. Metodología, epistemología, gnoseología y ontología»: REDHES 14: 59-92.

Schukoske, J. E. (2009). "Legal Education Reform in India: Dialogue Among Indian Law Teachers». Social Science Research Network, (Rochester, NY, 1 de September): 251-279.

Shady Solís, R. y Leyva, C. (eds.) (2003). La ciudad sagrada de Caral-Supe: los orígenes de la civilización andina y la formación del Estado prístino en el antiguo Perú. Lima: Instituto Nacional de Cultura, Proyecto Especial Arqueológico CaralSupe.

Silva, L. (1976). Teoría y práctica de la ideología. México: Nuestro Tiempo.

. (1977). La plusvalía ideológica. (4ta. Ed.) Caracas: Universidad Central de Venezuela.

. (1983). La alienación como sistema: La teoría de la alienación en la obra de Marx. Caracas: Alfadil.

Smorgunova, V. (s. f.). "Legal Education in Modern Russian». Herzen State Pedagogical University of Russia Faculty of Law, Russia (s. f.): 1-5.

Spencer, A. B. (2012). "The law school critique in historical perspective». 
Washington and Lee Law Review 69: 1949-2063.

Tingting, Q. (2010). Les pétitions des professeurs de droit en Chine. Master recherche en droit, mention sociologie du droit et communication juridique. Paris: Université Paris II.

Turull i Rubinat M. y Rovira A. (Eds.) (2014). La enseñanza del derecho en Europa y América: planes de estudio, metodologías, evaluación y acceso a las profesiones jurídicas. Barcelona: Octaedro-ICE. 